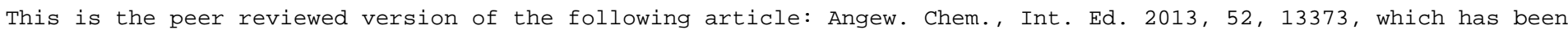

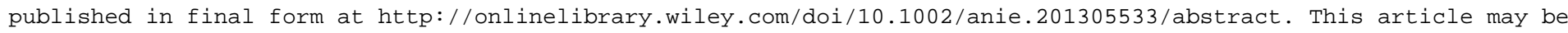
used for non-commercial purposes in accordance With Wiley-VCH Terms and Conditions for self-archiving

\title{
Total Synthesis and Biological Evaluation of Jerantinine $\mathbf{E}^{* *}$
}

\author{
Reto Frei, Davide Staedler, Aruna Raja, Raimo Franke, Florenz Sasse, Sandrine Gerber-Lemaire \\ and Jérôme Waser*
}

Indole alkaloids have attracted the attention of synthetic chemists because of their intriguing structural features and remarkable bioactivities. This interest is perhaps best represented by the Vinca alkaloid vinblastine (1), isolated from Catharanthus roseus, which is currently among the foremost drugs used to combat cancer. ${ }^{[1]}$ However, de novo synthesis of novel vinblastine analogues remains a daunting task due to its highly complex structure. Consequently, the discovery of simpler bioactive Aspidosperma alkaloids is of high interest to facilitate the discovery of new anti-cancer agents. Not surprisingly, intensive synthetic efforts have been directed towards the synthesis of vindoline (2), ${ }^{[2]}$ or simpler Aspidosperma alkaloids such as aspidospermidine (3) ${ }^{[3]}$ and vincadifformine (4) ${ }^{[4]}$

In 2008, Kam and co-workers reported the isolation of seven new Aspidosperma indole alkaloids, jerantinine A-G, from a leaf extract of the Malayan plant Tabernaemontana corymbosa. ${ }^{[5]}$ Among them was jerantinine E (5), which is structurally related to vincadifformine (4) but has a more oxidized indole core. The jerantinines displayed significant cytotoxic activity (half maximal inhibitory concentration; $\mathrm{IC}_{50}=0.27-0.96 \mu \mathrm{g} / \mathrm{L}(0.70-2.50 \mu \mathrm{M})$ ) against human $\mathrm{KB}$ cells, which is rare among simple Aspidosperma alkaloids. Nevertheless, the mode of action for the cytotoxicity of the jerantinines is currently unknown. Furthermore, the highly oxygenated core of the jerantinines renders them challenging synthetic targets and a total synthesis of jerantinines A-G has not yet been reported.

Herein, we describe the first total synthesis of $( \pm)$-jerantinine E (5) in 17 steps and $15.7 \%$ overall yield from $\delta$-valerolactam (10).

[*] Dr. Reto Frei and Prof. Dr. J. Waser

Laboratory of Catalysis and Organic Synthesis

Ecole Polytechnique Fédérale de Lausanne

EPFL SB ISIC LCSO, BCH 4306, 1015 Lausanne (CH)

Fax: (+)41216939700

E-mail: jerome.waser@epfl.ch

Homepage: http://lcso.epfl.ch/

Ms. Aruna Raja, Dr. Raimo Franke, Dr. Florenz Sasse

Department of Chemical Biology

Helmholtz Centre for Infection Research, Inhoffenstrasse 7,

D-38124 Braunschweig, Germany

Mr. Davide Staedler, Dr. Sandrine Gerber-Lemaire

Laboratory of Synthesis and Natural Products

Ecole Polytechnique Fédérale de Lausanne

EPFL SB ISIC LSPN, BCH 5302, 1015 Lausanne (CH)

[**] We thank F. Hoffmann-La Roche Ltd for an unrestricted research grant and the Swiss State Secretariat for Education, Research and Innovation for financial support (Grant number C10.0116 in framework of the COST action CM0804). We thank Dr. Filippo De Simone (LCSO) for the first synthesis of Weinreb amide 8 and helpful discussions, as well as Prof. T. S. Kam from the University of Malaya for a copy of the original NMR spectra of Jerantinine E (5).

Supporting information for this article is available on the WWW under http://www.angewandte.org or from the author.
The availability of a significant amount of the natural product permitted the separation of the enantiomers, in-depth biological evaluation of the cytotoxic activity in various human cancer cell lines, as well as a first investigation on the origin of the observed cytotoxicity.
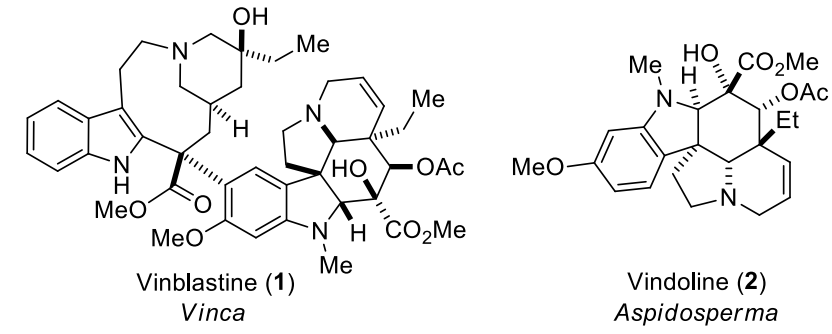

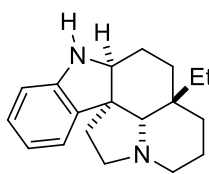

Aspidospermidine (3) Aspidosperma

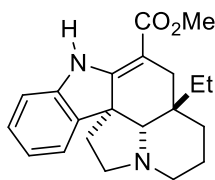

Vincadifformine (4) Aspidosperma

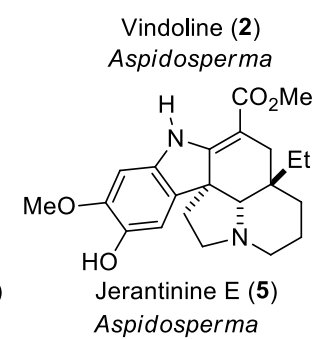

Figure 1. Vinca and Aspidosperma alkaloids.

As shown in our retrosynthesis (Scheme 1, A), we envisaged that the free hydroxyl group of jerantinine E (5) could be generated via selective demethylation during the last step of the total synthesis. This strategy would simplify the synthesis by avoiding a multi-step hydroxyl group protecting/deprotecting sequence. We expected this selective methyl group removal to proceed under oxidative conditions due to the presence of the electron-rich nitrogen in the para position. ${ }^{[6]}$ As such, the indole core could be oxidized to the corresponding iminoquinone followed by in situ reduction to give $\mathbf{5}$. We next planned to build-up the e-ring system by a bis-alkylation and to install the methyl ester group on the c-ring via acylation using Mander's reagent. This ring formation/acylation sequence was developed during the synthesis of Aspidosperma alkaloids by Rawal and co-workers, albeit with a less oxygenated indole core. ${ }^{[3 \mathrm{~d}]}$ The requisite starting material for this sequence could be generated through $N$-protecting group removal and deoxygenation of intermediate 6. Tetracyclic product $\mathbf{6}$ was envisaged to be accessed by a selective cyclization (formal homo-Nazarov reaction) of aminocyclopropane 7, previously developed in our group, ${ }^{[7]}$ forming the central ring system c. Cyclization precursor $\mathbf{7}$ would finally be obtained by adding an organometallic reagent derived from commercially available indole $\mathbf{9}$ onto Weinreb amide $\mathbf{8}$.

Our synthesis commenced with the coupling of Weinreb amide $\mathbf{8}$, obtained in seven steps and $51 \%$ overall yield from commercially available $\delta$-valerolactam (10), ${ }^{[7]}$ and the bis-lithiated organolithium reagent derived from $N$-carboxy indole 11 (Scheme 1, B). Selecting the carboxylate as $N$-indole protecting group had a dual purpose, as it directed the lithiation to the $\mathrm{C}-2$ indole position and was readily removed during the aqueous work-up. The desired aminocyclopropane 7 was obtained in $72 \%$ yield. The formal homo- 
Nazarov cyclization of $\mathbf{7}$ afforded the cis-diastereoisomer of $\mathbf{6}$ exclusively in $85 \%$ yield with high $\mathrm{C}-3$ regioselectivity. ${ }^{[8]}$

At this point of the synthesis, four of the five ring systems of jerantinine E (5) were installed and we turned our attention to the formation of the e-ring. Deoxygenation of the ketone was unexpectedly challenging however, and the reported one-step reduction by Wenkert and co-workers led only to decomposition of the starting material. ${ }^{[9]}$ Thus, a two-step procedure was devised to remove the ketone functionality. Alcohol 12 was obtained in $96 \%$ yield employing lithium aluminium hydride under mild conditions. We reasoned that an ionic reduction could be ideal at this stage to remove the hydroxyl group, as a facile carbocation formation can be envisaged due to the highly electron-rich adjacent indole ring system. Indeed, treatment of alcohol $\mathbf{1 2}$ with boron trifluoride etherate at low temperature led to carbocation formation, which upon triethylsilane mediated hydride transfer gave intermediate $\mathbf{1 3}$ in $\mathbf{9 3 \%}$ yield. Compound $\mathbf{1 3}$ was highly unstable under air and the subsequent transformations, including Cbz-removal and Rawal's three-step procedure, ${ }^{[3 \mathrm{~d}]}$ had to be completed in one-pot while carefully using Schlenk techniques. Although liquid chromatography-mass spectrometry analysis of the reaction progress indicated that Cbz-deprotection, alkylation, mesylation and basemediated ring-closure were working, we were unable to isolate the desired pentacyclic compound $\mathbf{1 4}$ as it immediately decomposed into several unidentifiable products during work-up.
At this point, it became clear that a new approach avoiding highly electron-rich intermediates and reactive imines, such as $\mathbf{1 4}$, had to be designed to gain access to jerantinine E (5). We speculated that these objectives could be realized by introducing the electronwithdrawing ester group present on the natural product prior to the instalment of the last ring system (Scheme 1, C). Thus, the presumably reactive imine double bond would migrate into conjugation with the ester group upon closure of the fifth ring system.

To test this hypothesis, we made use of the facile carbocation formation through the treatment of alcohol $\mathbf{1 2}$ with boron trifluoride etherate. The carbocation intermediate was reacted with trimethylsilylcyanide and the resulting nitrile product was transformed into ester 15 via Pinner methanolysis, Cbz-deprotection and alkylation with 2-bromoethanol. Gratifyingly, intermediate $\mathbf{1 5}$ successfully underwent the ring-closing procedure, generating pentacyclic product 16 in $85 \%$ yield. As postulated, the presence of the ester group facilitated double bond migration into conjugation, producing a perfectly stable compound. Finally, selective demethylation of $\mathbf{1 6}$ was possible via cerium ammonium nitrate mediated oxidation followed by in situ reduction with sodium dithionite to give jerantinine $\mathrm{E}$ (5) in 79\% yield. Thus, the first total synthesis of jerantinine E (5) was accomplished in 17 steps and a $15.7 \%$ overall yield starting from $\delta$-valerolactam $(\mathbf{1 0})$.

A

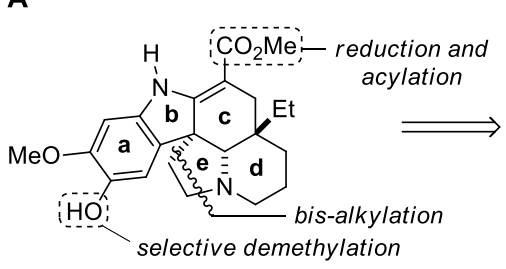

Jerantinine $\mathrm{E}$ (5)

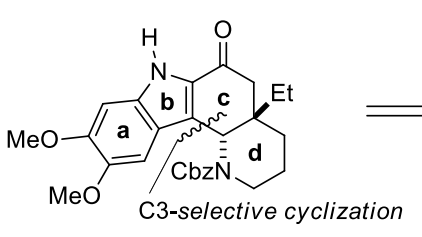

6

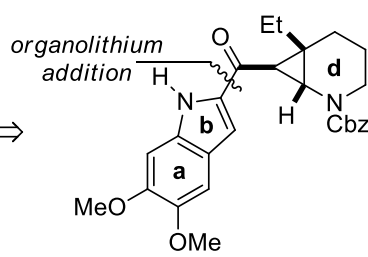

7
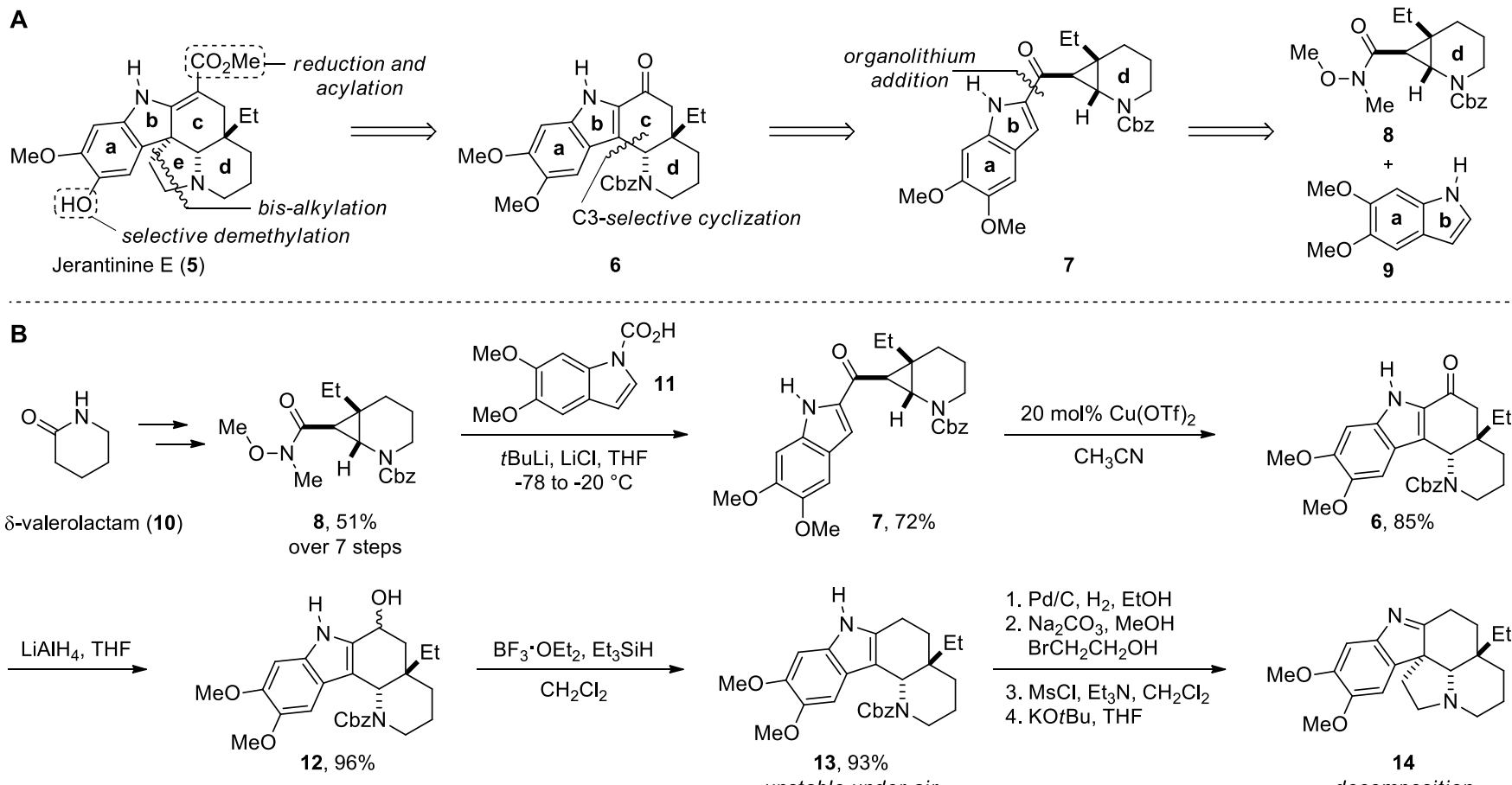

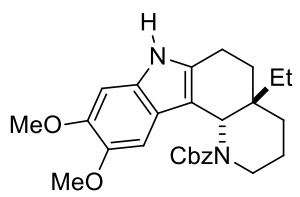

$13,93 \%$

unstable under air

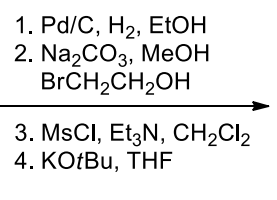

4. KOtBu, THF

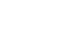

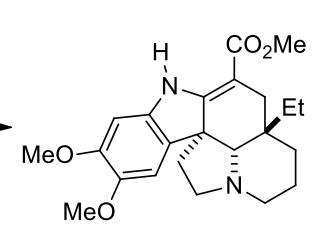

16, $85 \%$ over 2 steps

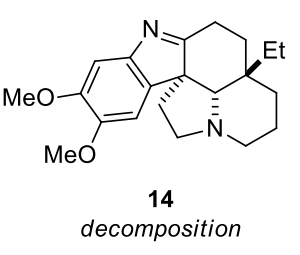

1. $\mathrm{BF}_{3} \cdot \mathrm{OEt}_{2}$

$\mathrm{Me}_{3} \mathrm{SiCN}, \mathrm{CH}_{2} \mathrm{Cl}_{2}$

2. $\mathrm{HCl}, \mathrm{MeOH}$, then $\mathrm{H}_{2} \mathrm{O}$

3. $\mathrm{Pd} / \mathrm{C}, \mathrm{H}_{2}, \mathrm{EtOH}$

$\mathrm{Na}_{2} \mathrm{CO}_{3}, \mathrm{MeOH}$

$\mathrm{BrCH}_{2} \mathrm{CH}_{2} \mathrm{OH}$

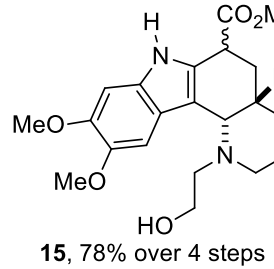

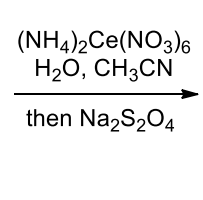

$\underset{2}{\stackrel{\mathrm{Na}_{2} \mathrm{~S}_{2} \mathrm{O}_{4} \mathrm{Ce}\left(\mathrm{NO}_{3}\right)_{6}}{\longrightarrow}}$

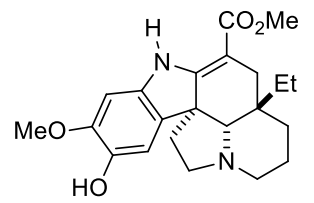

jerantinine $E$ (5), 79\% overall $15.7 \%$ over 17 steps

Scheme 1. Retrosynthetic analysis (A), initial approach (B) and final (C) synthetic route for the total synthesis of jerantinine $E(\mathbf{5})$. 
With significant amounts of jerantinine E (5) in hand, we focused our attention on exploring its potential as an anticancer agent. Considering that breast and lung cancers are among the most frequent and fatal types of this disease, ${ }^{[10]}$ two human-derived breast- and lung-cancer cell lines were selected to investigate the cytotoxic activity of jerantinine E (5). A first moderately invasive cell line (MCF-7) was selected from breast ductal carcinoma in conjunction with a second highly invasive breast cancer cell line (MDA-MB-231). ${ }^{[11]}$ The human adenocarcinoma cell line (A549) derived from alveolar epithelial cells and adenosquamous carcinoma cell line (HTB-178) ${ }^{[12]}$ were chosen to serve as lung cancer model cell lines. The two enantiomers of jerantinine E (5) were first separated by chiral chromatography and their cytotoxic activity examined separately. The cellular assays showed that only naturally occurring (-)-jerantinine E (5) was significantly bio-active (Figure 2). ${ }^{[13]}$
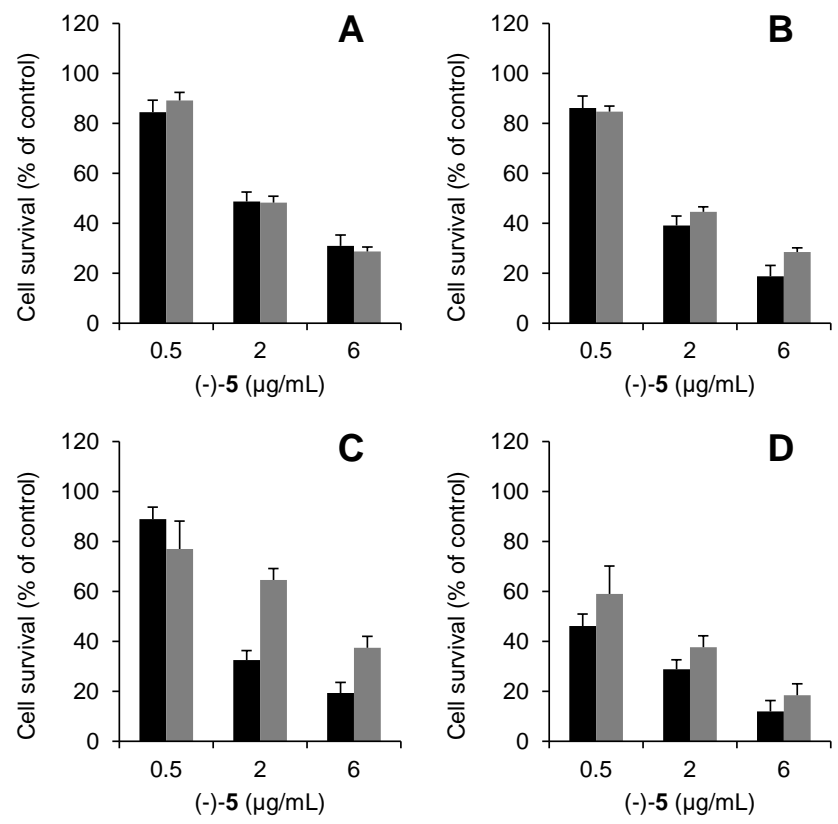

Figure 2. Effect of (-)-jerantinine $\mathrm{E}(\mathbf{5})$ on the survival of breast cancer cells (A ( $24 \mathrm{~h}$ exposure) and $\mathbf{B}$ ( $72 \mathrm{~h}$ exposure) black bar: MDA-MB231, grey bar: MCF-7) and lung cancer cells, (C (24 h exposure) and D (72 h exposure) black bar: A549, grey bar: HTB-178). Please see the Supporting Information for additional experimental details.

Both breast cancer cell lines gave comparable inhibition values for cell growth after 24 and 72 hours (Figure 2A and 2B) having IC 50 -values between 1.7 to $2.3 \mu \mathrm{g} / \mathrm{mL}$ (4.4 to $6.0 \mu \mathrm{M})$. The screening assay in the two lung cancer cell lines revealed that (-)jerantinine E (5) exhibits greater cytotoxicity against the adenocarcinoma A549 cell line compared to adenosquamous HTB178 cells at both, 24 and 72 hours (Figure $2 \mathrm{C}$ and 2D). In the four tested human cancer cell lines, (-)-jerantinine E (5) displayed the highest cytotoxic effect in the A549 cell line with an $\mathrm{IC}_{50}$ after 24 and 72 hours of exposure of 1.6 and $0.4 \mu \mathrm{g} / \mathrm{mL}(4.2$ and $1.0 \mu \mathrm{M})$, respectively (Figure $2 \mathrm{C}$ and $2 \mathrm{D}$ ).

After studying the cytotoxic activity profile for jerantinine E (5), we set out to elucidate possible mechanisms for the observed cell growth inhibition. First, a cell migratory assay was carried out with the above described human-derived cancer cell lines. Inhibition of cell migration ranging between 50 and $90 \%$ was observed in all four cancer cell lines after 15 hours of exposure to 2 and $6 \mu \mathrm{g} / \mathrm{mL}$ of jerantinine E (5). ${ }^{[14]}$ Second, an impedance study of jerantinine E (5) against the L-929 (mouse fibroblast) cell line was carried out. In this assay, cells are placed on a gold electrode plate and treated with the test compound at their $\mathrm{IC}_{90}$ concentration. During a five day time period, the change in impedance, due to changes in the morphological state of the cells upon compound exposure, is measured. Through cluster analysis, the obtained data can then be matched to the data of a reference compound with a known target. ${ }^{[15]}$ Using this approach, we found that jerantinine E (5) displayed an impedance profile in accordance with reference compounds, such as colchicine, which affects the microtubule network. An immunofluorescent staining assay was then carried out (Figure 3) with PtK2 kidney cells to confirm this possible mode of action. As shown in Figure 3B, multi-lobed nuclei were observed after exposing PtK2 kidney cells to $2 \mu \mathrm{g} / \mathrm{mL}$ jerantinine E (5). Furthermore, disruption of the microtubule network already became apparent at this stage and is nearly complete at higher concentration (Figure 3C and 3D). Such observations further suggested microtubule disruption as a plausible mode of action. To confirm this hypothesis, the ability of both enantiomers and racemic jerantinine $\mathrm{E}(\mathbf{5})$ to inhibit tubulin polymerization was studied on the purified tubulin. The assay showed (-)-jerantinine E (5) to be a potent inhibitor of tubulin polymerization with an $\mathrm{IC}_{50}$-value of 0.17 $\mu \mathrm{g} / \mathrm{mL}(0.45 \mu \mathrm{M}){ }^{[14]}$ It is noteworthy that (-)-jerantinine E (5) proved to be even slightly more active than the known microtubule skeleton disruptor colchicine.
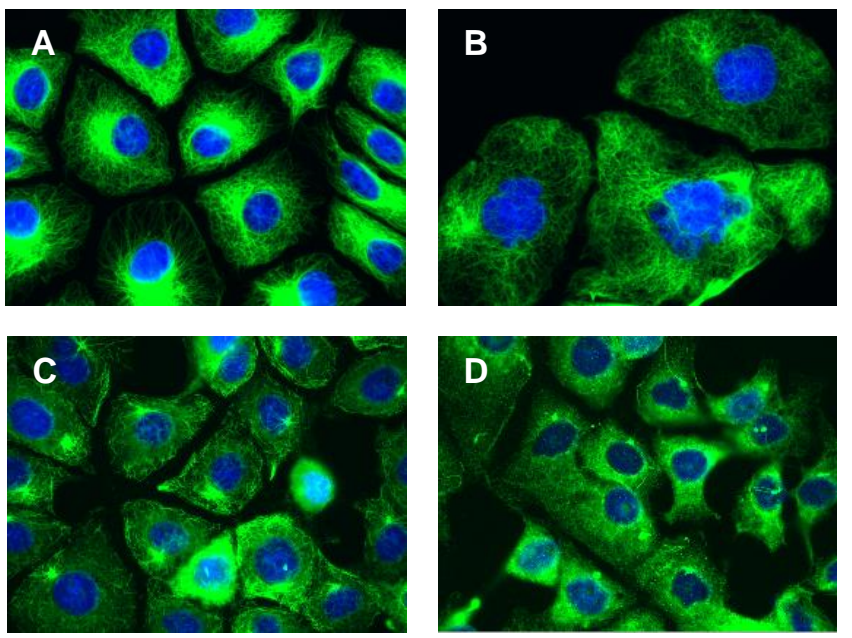

Figure 3. Immunofluorescent staining of untreated PtK2 kidney cells (A) and cells exposed to $2 \mu \mathrm{g} / \mathrm{mL}$ (B), $6 \mu \mathrm{g} / \mathrm{mL}$ (C) and $10 \mu \mathrm{g} / \mathrm{mL}$ (D) jerantinine $E(5)$ showing the effect on microtubules (green) and the cell nucleus (blue). Please see the Supporting Information for additional experimental details.

In conclusion, we have described the first total synthesis of the indole alkaloid jerantinine E (5) in 17 steps and $15.7 \%$ overall yield starting from $\delta$-valerolactam (10). An efficient and highly selective formal homo-Nazarov cyclization of an aminocyclopropane was used to give access to four of the five rings contained in the complex polycyclic core of the natural product. A novel strategy to install the ester group onto the highly sensitive indole alkaloid core was devised, addressing the challenges represented by the highly oxygenated and reactive core of the molecule. Lastly, a late-stage selective demethylation led to an efficient synthetic sequence. The total synthesis enabled us to investigate the biological profile of jerantinine E (5). The cytotoxic activity of the natural product was determined in several human-derived breast and lung cancer cell lines, displaying for instance an $\mathrm{IC}_{50}$ value of $0.4 \mu \mathrm{g} / \mathrm{mL}(1.0 \mu \mathrm{M})$ in 
the A549 lung cancer cell line. Investigations into the mode of action suggested that jerantinine E (5) acts via disruption of the microtubule network, as indicated by its potent inhibitory activity displayed in tubulin polymerization. Future work will focus on the synthesis of analogues for a detailed structure-activity relationship study with the goal of finding compounds with improved activity and potency. Additional experiments to elucidate the exact origin of the observed microtubule disruption will also be considered to further understand the source of the observed cytotoxicity.

Received: ((will be filled in by the editorial staff)) Published online on ((will be filled in by the editorial staff))

Keywords: Total Synthesis - Alkaloids · Cancer · Indoles .

Microtubules · Bioactive Natural Products.

[1] a) S. E. Malawista, H. Sato, K. G. Bensch, Science 1968, 160, 770; b) B. Gigant, C. G. Wang, R. B. G. Ravelli, F. Roussi, M. O. Steinmetz, P. A. Curmi, A. Sobel, M. Knossow, Nature 2005, 435, 519; c) F. Gueritte, J. Fahy, The vinca Alkaloids, Anticancer agents from natural products, (Eds: D. J. C. Newman, G. M. Kingston) Taylor \& Francis group, 2005.

[2] Selected examples: a) M. Ando, G. Buchi, T. Ohnuma, J. Am. Chem. Soc. 1975, 97, 6880; b) J. P. Kutney, U. Bunzlitrepp, K. K. Chan, J. P. D. Souza, Y. Fujise, T. Honda, J. Katsube, F. K. Klein, A. Leutwiler, S. Morehead, M. Rohr, B. R. Worth, J. Am. Chem. Soc. 1978, 100, 4220; c) P. L. Feldman, H. Rapoport, J. Am. Chem. Soc. 1987, 109, 1603; d) H. Ishikawa, G. I. Elliott, J. Velcicky, Y. Choi, D. L. Boger, J. Am. Chem. Soc. 2006, 128, 10596; e) D. Kato, Y. Sasaki, D. L. Boger, J. Am. Chem. Soc. 2010, 132, 3685.

[3] Selected examples: a) G. Stork, J. E. Dolfini, J. Am. Chem. Soc. 1963, 85, 2872; b) J. P. Kutney, Abdurahm.N, P. Lequesne, E. Piers, I. Vlattas, J. Am. Chem. Soc. 1966, 88, 3656; c) T. Gallagher, P. Magnus, J. C. Huffman, J. Am. Chem. Soc. 1982, 104, 1140; d) S. A. Kozmin, T. Iwama, Y. Huang, V. H. Rawal, J. Am. Chem. Soc. 2002, 124, 4628; e) J. P. Marino, M. B. Rubio, G. F. Cao, A. de Dios, J. Am. Chem. Soc. 2002, 124, 13398; f) I. Coldham, A. J. M. Burrell, L. E. White, H. Adams, N. Oram, Angew. Chem. 2007, 119, 6271; Angew. Chem., Int. Ed. 2007, 46, 6159; g) C. Sabot, K. C. Guerard, S. Canesi, Chem. Commun. 2009, 2941; h) L. McMurray, E. M. Beck, M. J. Gaunt, Angew. Chem. 2012, 124, 9422; Angew. Chem., Int. Ed. 2012 51, 9288; i) L. Jiao, E. Herdtweck, T. Bach, J. Am. Chem. Soc. 2012, 134, 14563; j) M. Kawano, T. Kiuchi, S. Negishi, H. Tanaka, T. Hoshikawa, J. Matsuo, H. Ishibashi, Angew. Chem. 2013, 125, 940; Angew. Chem., Int. Ed. 2013, 52, 906.

[4] Selected examples: a) J. P. Kutney, R. T. Brown, E. Piers, J. Am. Chem. Soc. 1964, 86, 2286; b) S. Kobayashi, G. Peng, T. Fukuyama, Tetrahedron Lett. 1999, 40, 1519.

[5] K. H. Lim, O. Hiraku, K. Komiyama, T. S. Kam, J. Nat. Prod. 2008, 71,1591 .

[6] a) G. Meunier, B. Meunier, J. Am. Chem. Soc. 1985, 107, 2558; b) J. D. White, K. M. Yager, T. Yakura, J. Am. Chem. Soc. 1994, 116 , 1831; c) M. Alvarez, M. A. Bros, G. Gras, W. Ajana, J. A. Joule, Eur. J. Org. Chem. 1999, 1173; d) M. B. Andrus, E. L. Meredith, E. J. Hicken, B. L. Simmons, R. R. Glancey, W. Ma, J. Org. Chem. 2003 68,8162 .

[7] a) F. De Simone, J. Gertsch, J. Waser, Angew. Chem. 2010, 122, 5903; Angew. Chem., Int. Ed. 2010, 49, 5767. b) F. De Simone, J. Waser, Chimia 2012, 66, 233.

[8] A 12:1 regioselectivity was observed for C3 vs N1 cyclization. For a further discussion of the selectivity of the cyclization reaction of aminocyclopropanes on indoles, see: a) F. De Simone, J. Waser, Synlett 2011, 589. b) F. De Simone, T. Saget, F. Benfatti, S. Almeida, J. Waser, Chem. Eur. J. 2011, 17, 14527.

[9] E. Wenkert, T. Hudlicky, J. Org. Chem. 1988, 53, 1953.

[10] J. Ferlay, D. M. Parkin, E. Steliarova-Foucher, Eur. J. Cancer 2010, 46,765 .
[11] D.Staedler, E. Idrizi, B. H. Kenzaoui, L. Juillerat-Jeanneret, Cancer chemother. pharmacol. 2011, 68, 1161.

[12] D. Staedler, T. Magouroux, R. Hadji, C. Joulaud, J. Extermann, S. Schwung, S. Passemard, C. Kasparian, G. Clarke, M. Gerrmann, Le R. Dantec, Y. Mugnier, D. Rytz, D. Ciepielewski, C. Galez, S. GerberLemaire, L. Juillerat-Jeanneret, L. Bonacina, J. P. Wolf, ACS nano 2012, 6, 2542.

[13] Please see the Supporting Information for exact $\mathrm{IC}_{50}$-values, including error range, for both enantiomers and racemic jerantinine $\mathrm{E}(\mathbf{5})$ in the four described cancer cell lines.

[14] Please see the Supporting Information for more details.

[15] a) K. Solly, X. Wang, X. Xu, B. Strulovici, W. Zheng, Assay Drug Dev. Technol. 2004, 2, 363; b) J. M. Atienza, N. Yu, S. L. Kirstein, B. Xi, X. Wang, X. Xu, Y. A. Abassi, Assay Drug Dev. Technol. 2006, 4 , 597; c) Y. A. Abassi, B. Xi, W. Zhang, P. Ye, S. L. Kirstein, M. R. Gaylord, S. C. Feinstein, X. Wang, X. Xu, Chem. Biol. 2009, 16, 712; d) W. N. Venables, B. D. Ripley, Modern Applied Statistics with S (4th ed.) 2002, Springer New York; e) G. R. Warnes gplots: Various $\mathrm{R}$ programming tools for plotting data. 2010. Retrieved from http://cran.rproject.org/package=gplots; f) N. Ke, B. Xi, P. Ye, W. Xu, M. Zheng, L. Mao, M. J. Wu, J. Zhu, J. Wu, W. Zhang, J. Zhang, J. Irelan, X. Wang, X. Xu, Y. A. Abassi, Anal. Chem. 2010, 82, 6495. 


\section{Natural Products}

Reto Frei, Davide Staedler, Aruna Raja, Raimo Franke, Florenz Sasse, Sandrine Gerber-Lemaire and Jérôme Waser

Page - Page

Total Synthesis and Biological Evaluation of Jerantinine $\mathrm{E}$.

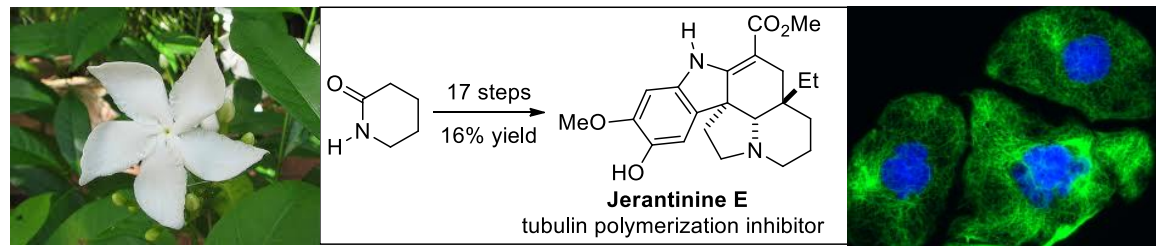

Nature's beauty: The first total synthesis of the alkaloid natural product jerantinine $E$ is reported. Based on a selective cyclization of an aminocyclopropane, the natural product could be accessed in 17 steps and $15.7 \%$ overall yield from commercially available $\delta$-valerolactam. Preliminary investigations into the bioactivity of jerantinine E demonstrated that it inhibits the polymerization of tubulin, displaying significant cytotoxicity and antimigratory activity against both breast and lung cancer cell lines. 


\section{Table of Contents}

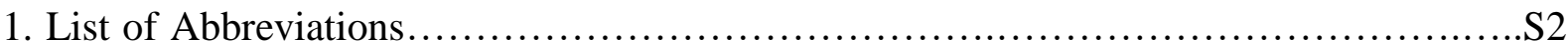

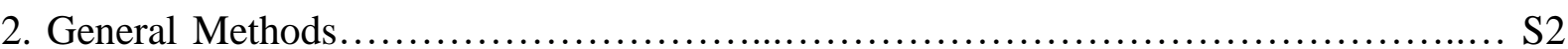

3. General Hydrogenolysis Procedure .................................................. S2

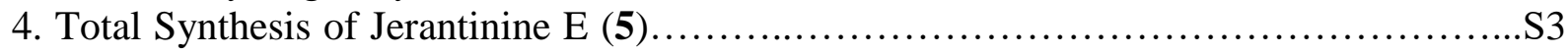

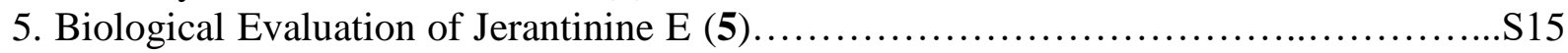

6. Spectra of New Compounds..................................................... 27 


\section{List of Abbreviations}

$\begin{array}{ll}\text { EtOAc } & \text { Ethyl acetate } \\ \text { DMTMM } & \text { Dimethoxytriazin- } N \text {-methylmorpholinium chloride } \\ \text { DCM } & \text { Dichloromethane } \\ \text { NMM } & N \text {-Methylmorpholine } \\ \text { THF } & \text { Tetrahydrofuran } \\ \text { Cbz } & \text { Carboxybenzyl } \\ \text { Ultra } & \mathrm{CH}_{2} \mathrm{Cl}_{2}: \mathrm{MeOH} 3: 1(\mathrm{v} / \mathrm{v}) \text { with } 5 \% \mathrm{NH}_{3}(\mathrm{aq} ., 25 \%) \\ \text { GHP } & \mathrm{General} \mathrm{hydrogenolysis} \mathrm{procedure}\end{array}$

\section{General Methods}

Technical grade solvents were used for quantitative flash chromatography. HPLC grade solvents purchased from Sigma-Aldrich or freshly distilled solvents were used for flash chromatography for compounds undergoing full characterization. Reaction solvents were dried by passage over activated alumina under nitrogen atmosphere $\left(\mathrm{H}_{2} \mathrm{O}\right.$ content $<30 \mathrm{ppm}$, Karl-Fischer titration). Commercially available reagents were purchased from Acros, Aldrich, Fluka, VWR, Aplichem or Merck and used without any further purification. Chromatographic purification was performed as flash chromatography using Macherey-Nagel silica 40-63, 60 $\AA$, using the solvents indicated as eluent with 0.1-0.5 bar pressure. TLC was performed on Merck silica gel 60 F254 TLC plates and visualized with UV light and permanganate stain. Melting points were measured on a calibrated Büchi B-540 melting point apparatus using open glass capillaries. ${ }^{1} \mathrm{H}$ NMR spectra were measured on a Brucker DPX-400 $400 \mathrm{MHz}$ spectrometer, all signals are reported in ppm with the corresponding internal solvent peak or TMS as standard. The data is being reported as ( $\mathrm{s}=$ singlet, $\mathrm{d}=$ doublet, $\mathrm{t}=$ triplet, $\mathrm{q}=$ quadruplet, qi $=$ quintet, $\mathrm{m}=$ multiplet or unresolved, $\mathrm{br}=$ broad signal, coupling constant $(\mathrm{s})$ in $\mathrm{Hz}$, integration; interpretation). ${ }^{13} \mathrm{C}$ NMR spectra were carried out with $1 \mathrm{H}$-decoupling on a Brucker DPX-400 $100 \mathrm{MHz}$. All signals are reported in ppm with the corresponding internal solvent signal or TMS as standard. Infrared spectra were obtained on a JASCO FT-IR B4100 spectrophotometer with an ATR PRO410-S and a ZnSe prisma and are reported as $\mathrm{cm}^{-1}(\mathrm{w}=$ weak, $\mathrm{m}=$ medium, $\mathrm{s}=$ strong, $\mathrm{sh}=$ shoulder). High resolution mass spectrometric measurements were performed by the mass spectrometry service of ISIC at the EPFL on a MICROMASS (ESI) Q-TOF Ultima API. Optical rotatory measurements were performed on a JASCO P-2000 Polarimeter.

\section{General Hydrogenolysis Procedure (GHP)}

A solution of of Cbz-protected amine $(0.02 \mathrm{M}$ in ethanol) was charged at room temperature with $\mathrm{Pd} / \mathrm{C}$ (0.1 eq.) and hydrogen gas was bubbled through the mixture until full conversion of the starting material was observed by TLC. ${ }^{1}$ The suspension was filtered through a short plug of celite (prewashed with DCM) using additional amounts of DCM and EtOAc to ensure that complete product elution form the plug was achieved. The organic layer was dried over $\mathrm{MgSO}_{4}$, filtered and concentrated in vacuo. No further purification was necessary.

\footnotetext{
${ }^{1} \mathrm{~A}$ batch to batch Pd/C dependency for the reaction time was observed. It is consequently important to carefully monitor the reaction via TLC analysis.
} 


\section{Total Synthesis of Jerantinine $E$}

Benzyl 5-ethyl-3,4-dihydropyridine-1(2H)-carboxylate (18)

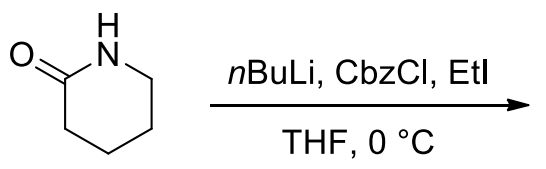

10<smiles>CCC1CCCN(C(=O)O[Na])C1=O</smiles>

17

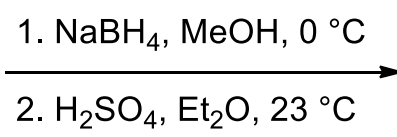

2. $\mathrm{H}_{2} \mathrm{SO}_{4}, \mathrm{Et}_{2} \mathrm{O}, 23^{\circ} \mathrm{C}$<smiles>CCC1=CN([O+])CCC1</smiles>

18

Following a slight modification of a reported procedure, ${ }^{2}$ a $1.6 \mathrm{M}$ solution of $n \mathrm{BuLi}$ in hexane $(90.0 \mathrm{~mL}, 144 \mathrm{mmol}, 2.20$ eq.) was added dropwise to a solution of $\delta$-valerolactam $(\mathbf{1 0}, 6.50$ $\mathrm{g}, 65.6 \mathrm{mmol}, 1.00$ eq.) in dry THF $(100 \mathrm{~mL})$ at $0{ }^{\circ} \mathrm{C}$. The resulting yellow solution was stirred at $0{ }^{\circ} \mathrm{C}$ for 30 minutes, after which freshly distilled ethyl iodide $(7.91 \mathrm{~mL}, 98.0 \mathrm{mmol}$, 1.50 eq.) was added. The reaction mixture was stirred for an additional 20 minutes at $0{ }^{\circ} \mathrm{C}$ before benzyl chloroformate $(9.83 \mathrm{~mL}, 68.8 \mathrm{mmol}, 1.05$ eq. $)$ was added. The reaction mixture was stirred for 30 minutes at $0{ }^{\circ} \mathrm{C}$, diluted with diethyl ether $(170 \mathrm{~mL})$ and washed with brine $(2 \times 70 \mathrm{~mL})$. The organic layer was dried over $\mathrm{MgSO}_{4}$, filtered and concentrated in vacuo. The crude product was purified by flash column chromatography (pentane:EtOAc 5:1) to yield lactam 17 (12.4 g, $47.5 \mathrm{mmol}, 72 \%)$ as a colorless oil. ${ }^{1} \mathrm{H}$ NMR $\left(\mathrm{CDCl}_{3}, 400 \mathrm{MHz}\right) \delta$ 7.46-7.39 (m, $2 \mathrm{H}, \operatorname{ArH}), 7.39-7.28(\mathrm{~m}, 3 \mathrm{H}, \operatorname{ArH}), 5.27\left(\mathrm{~s}, 2 \mathrm{H}, \mathrm{OCH}_{2}\right), 3.85-3.76(\mathrm{~m}, 1 \mathrm{H}$, $\left.\mathrm{NCH}_{2}\right), 3.73-3.64\left(\mathrm{~m}, 1 \mathrm{H}, \mathrm{NCH}_{2}\right), 2.40-2.29(\mathrm{~m}, 1 \mathrm{H}, \mathrm{CHCO}), 2.07-1.73\left(\mathrm{~m}, 4 \mathrm{H} ; \mathrm{CH}_{2} \mathrm{CH}_{2}\right)$,

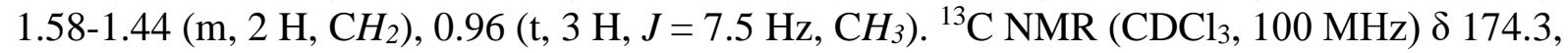
$154.4,135.6,126.8,128.3,128.1,68.4,46.2,45.4,25.5,24.2,21.7,11.5$. The values of the NMR spectra are in accordance with reported literature data. ${ }^{3}$

Following a reported procedure, ${ }^{4}$ sodium borohydride $(1.27 \mathrm{~g}, 34.0 \mathrm{mmol}, 1.20$ eq.) was added portionwise to a solution consisting of Cbz-protected lactam (17, $7.40 \mathrm{~g}, 28.3 \mathrm{mmol}$, 1.00 eq.) and methanol $(150 \mathrm{~mL})$ at $0{ }^{\circ} \mathrm{C}$. The reaction mixture was stirred at $0{ }^{\circ} \mathrm{C}$ for two hours and then quenched with ice water $(10 \mathrm{~mL})$. The mixture was diluted with water $(100$ $\mathrm{mL})$ and extracted with EtOAc $(3 \times 100 \mathrm{~mL})$. The combined organic layers were washed with brine $(100 \mathrm{~mL})$, dried over $\mathrm{MgSO}_{4}$, filtered and concentrated in vacuo. The resulting colorless oil was dissolved in dry diethyl ether $(75 \mathrm{~mL})$ and concentrated sulfuric acid $(30 \mu \mathrm{L})$ was added at room temperature. The reaction mixture was stirred at room temperature for 30 minutes, then quenched with solid $\mathrm{K}_{2} \mathrm{CO}_{3}$ and dried with $\mathrm{MgSO}_{4}$. The suspension was filtered and concentrated in vacuo to afford $18(6.82 \mathrm{~g}, 27.8 \mathrm{mmol}, 98 \%)$ as a colorless oil. ${ }^{1} \mathrm{H}$ NMR $\left(\mathrm{CDCl}_{3}, 400 \mathrm{MHz}\right) \delta 7.42-7.28(\mathrm{~m}, 5 \mathrm{H}, \mathrm{Ar} H), 6.70(\mathrm{~s}, 0.45 \mathrm{H}$, alkene- $H$ rotamer A), $6.60(\mathrm{~s}$, $0.55 \mathrm{H}$, alkene- $H$ rotamer B), $5.19\left(\mathrm{~s}, 1.1 \mathrm{H}, \mathrm{OCH}_{2}\right.$ rotamer B), $5.17\left(\mathrm{~s}, 0.9 \mathrm{H}, \mathrm{OCH}_{2}\right.$ rotamer A), $3.57\left(\mathrm{~m}, 2 \mathrm{H}, \mathrm{NCH}_{2}\right), 2.07-1.94(\mathrm{~m}, 4 \mathrm{H}), 1.82(\mathrm{~m}, 2 \mathrm{H}), 1.06-0.97\left(\mathrm{~m}, 3 \mathrm{H} ; \mathrm{CH}_{3}\right) .{ }^{13} \mathrm{C}$ NMR $\left(\mathrm{CDCl}_{3}, 100 \mathrm{MHz}\right)$ (rotamers!) $\delta 153.4,153.0,136.5,136.4,128.3,127.9,127.8,121.0$, $120.6,119.1,118.7,67.1,67.0,41.9,41.8,28.1,28.1,24.8,24.7,21.6,21.6,12.6,12.4$. The values of the NMR spectra are in accordance with reported literature data. ${ }^{2}$

\footnotetext{
${ }^{2}$ P. A. Grieco, M. D. Kaufman, J. Org. Chem. 1999, 64, 7586-7593.

${ }^{3}$ F. De Simone, J. Gertsch, J. Waser, Angew. Chem. Int. Ed. 2010, 49, 5767-5770.

${ }^{4}$ Y. Takeuchi, K. Azuma, M. Oshige, H. Abe, H. Nishioka, K. Sasaki, T. Harayama, Tetrahedron 2003, 59, 1639-1646.
} 


\section{2-((Benzyloxy)carbonyl)-6-ethyl-2-azabicyclo[4.1.0]heptane-7-carboxylic acid (20)}
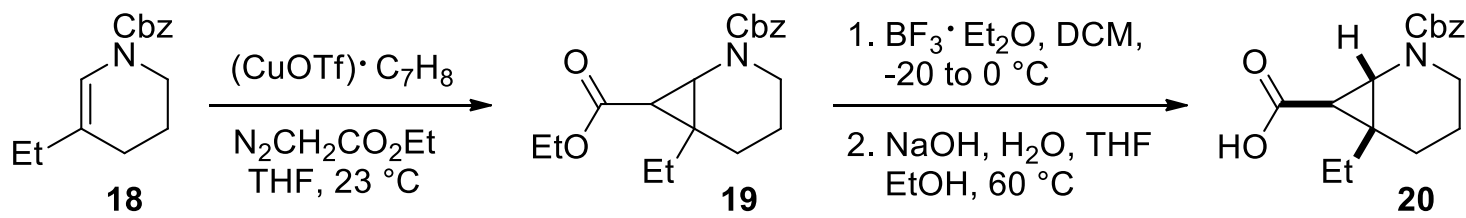

Following a slight modification of a reported procedure, ${ }^{5}$ a solution of ethyl diazoacetate (6.05 mL, $57.1 \mathrm{mmol}, 4.00$ eq.) in dry DCM (14 mL) was added to a solution of enamine 18 (3.50 g, $14.3 \mathrm{mmol}, 1.00 \mathrm{eq}$.$) and copper triflate (I) toluene complex (148 mg, 0.286 \mathrm{mmol}$, 0.0200 eq.) in DCM (14 mL) over $18 \mathrm{~h}(1.3 \mathrm{~mL} / \mathrm{h})$ via syringe pump. After the addition was complete, the reaction was concentrated in vacuo and purified by flash column chromatography (pentane:EtOAc 15:1 to pentane:EtOAc 10:1) to yield 19 (3.67 g, 11.3 $\mathrm{mmol}, 78 \%$ ) as colorless oil.

Following a reported procedure, ${ }^{1}$ the mixture of exo and endo esters $(\mathbf{1 9}, 2.13 \mathrm{~g}, 6.43 \mathrm{mmol}$, 1.00 eq.) in $\mathrm{DCM}(25 \mathrm{~mL})$ was treated at $-20{ }^{\circ} \mathrm{C}$ with freshly distilled $\mathrm{BF}_{3}$-etherate $(210 \mu \mathrm{L}$, $0.964 \mathrm{mmol}, 0.150$ eq.). The reaction was allowed to warm up to $0{ }^{\circ} \mathrm{C}$ over a two hour time period during which the isomerization went to completion. The reaction was quenched with triethylamine $(1.5 \mathrm{~mL})$, diluted with diethyl ether $(75 \mathrm{~mL})$ and extracted with water $(50 \mathrm{~mL})$. The aqueous layer was extracted with additional portions of diethyl ether $(2 \times 30 \mathrm{~mL})$ and the combined organic layers were washed with brine $(50 \mathrm{~mL})$, dried over $\mathrm{MgSO}_{4}$, filtered and concentrated in vacuo to afford a pale yellow oil (2.13 g, $6.43 \mathrm{mmol}$, quant.), which was used directly in the next step. Thus, the ester-intermediate $(2.13 \mathrm{~g}, 6.43 \mathrm{mmol}, 1.00 \mathrm{eq}$.$) was$ dissolved in a mixture of $\mathrm{H}_{2} \mathrm{O}$ :THF: $\mathrm{EtOH} \mathrm{1:1:3} \mathrm{(total} \mathrm{volume}=35 \mathrm{~mL}$ ) and cooled to $0{ }^{\circ} \mathrm{C}$. Next, $\mathrm{NaOH}$ (2.31 g, $57.8 \mathrm{mmol}, 9.00$ eq.) was added portionwise and the resulting solution was heated at $60{ }^{\circ} \mathrm{C}$ for 90 minutes. The mixture was diluted with water $(30 \mathrm{~mL})$ and extracted with diethyl ether $(3 \times 30 \mathrm{~mL})$. The combined organic layers were washed with water $(2 \times 30 \mathrm{~mL})$. The combined aqueous layers were acidified with $1.0 \mathrm{M}$ aq. $\mathrm{HCl}$ to $\mathrm{pH}=$ 2 , followed by extraction with DCM $(3 \times 40 \mathrm{~mL})$. The combined organic layers were dried over $\mathrm{MgSO}_{4}$, filtered and concentrated in vacuo to give 20 (1.87 g, $6.17 \mathrm{mmol}, 96 \%$ over two steps) as a white solid. ${ }^{1} \mathrm{H} \mathrm{NMR}\left(\mathrm{CDCl}_{3}, 400 \mathrm{MHz}\right) \delta$ 7.39-7.21 (m, $\left.5 \mathrm{H}, \mathrm{ArH}\right)$, 5.23-5.09 (m, $\left.2 \mathrm{H}, \mathrm{OCH}_{2}\right), 3.86\left(\mathrm{dt}, 0.7 \mathrm{H}, J=12.5,3.1 \mathrm{~Hz}, \mathrm{NCH}_{2}\right.$ rotamer A), $3.73\left(\mathrm{~m}, 0.3 \mathrm{H}, \mathrm{NCH}_{2}\right.$ rotamer B), $3.55(\mathrm{~d}, 0.3 \mathrm{H}, J=3.5 \mathrm{~Hz}, \mathrm{NCH}$ rotamer $\mathrm{B}), 3.49(\mathrm{~d}, 0.7 \mathrm{H}, J=3.6 \mathrm{~Hz}, \mathrm{NCH}$ rotamer A), $2.77\left(\mathrm{dt}, 0.3 \mathrm{H} . J=12.5,1.7 \mathrm{~Hz}, \mathrm{NCH}_{2}\right.$ rotamer B), $2.66(\mathrm{dt}, 0.7 \mathrm{H}, J=12.5,3.4$ $\mathrm{Hz}, \mathrm{NCH}_{2}$ rotamer A), $2.05(\mathrm{~m}, 1 \mathrm{H}, \mathrm{CHCO}), 1.93-1.12\left(\mathrm{~m}, 6 \mathrm{H}, \mathrm{CH}_{2}\right), 0.99(\mathrm{t}, 1 \mathrm{H}, J=7.2$ $\mathrm{Hz}, \mathrm{CH}_{3}$ rotamer B), $0.93\left(\mathrm{t}, 2 \mathrm{H}, J=7.4 \mathrm{~Hz}, \mathrm{CH}_{3}\right.$ rotamer A). ${ }^{13} \mathrm{C} \mathrm{NMR}\left(\mathrm{CDCl}_{3}, 100 \mathrm{MHz}\right)$ (rotamers!) $\delta 177.2,176.9,156.2,136.5,128.5,128.4,128.1,127.7,127.2,67.1,67.0,44.9$, $44.8,41.5,41.1,34.7,34.0,31.1,30.6,25.9,25.7,21.5,21.3,20.9,10.3,9.9$. The values of the NMR spectra are in accordance with reported literature data. ${ }^{2}$

\footnotetext{
${ }^{5}$ R. Beumer, C. Bubert, C. Cabrele, O. Vielhauer, M. Pietzsch, O. Reiser, J. Org. Chem. 2000, 65, 8960-8969.
} 
Benzyl 6-ethyl-7-(methoxy(methyl)carbamoyl)-2-azabicyclo[4.1.0]heptane-2-carboxylate (8)

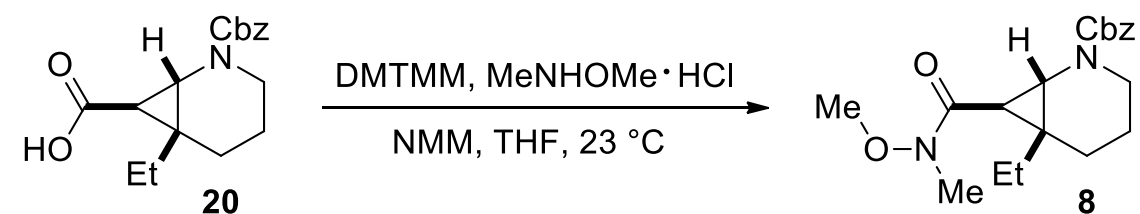

Freshly prepared dimethoxytriazin- $N$-methylmorpholinium chloride ${ }^{6}$ (DMTMM, 2.43 g, 8.79 mmol, 1.50 eq.) was added to a solution consisting of carboxylic acid 20 (1.78 g, $5.86 \mathrm{mmol}$, 1.00 eq.) and dry THF $(20 \mathrm{~mL})$. The resulting white suspension was stirred at room temperature for one hour, after which $\mathrm{N}, O$-dimethylhydroxylamine hydrochloride $(572 \mathrm{mg}$, $5.86 \mathrm{mmol}, 1.00$ eq.) and $N$-methylmorpholine (NMM, $1.29 \mathrm{~mL}, 11.7 \mathrm{mmol}, 2.00$ eq.). The reaction mixture was stirred for 48 hours at room temperature followed by quenching with $5 \%$ aq. citric acid $(30 \mathrm{~mL})$. The mixture was extracted with diethyl ether $(3 \times 30 \mathrm{~mL})$ and the combined organic layers were dried over $\mathrm{MgSO}_{4}$, filtered and concentrated in vacuo. The crude oil was purified by flash column chromatography (hexane:EtOAc 4:1) to yield Weinreb-amide 8 (1.97 g, $5.68 \mathrm{mmol}, 97 \%)$ as a colorless oil. ${ }^{1} \mathrm{H} \mathrm{NMR}\left(\mathrm{CDCl}_{3}, 400 \mathrm{MHz}\right) \delta$ 7.35-7.19 (m, $5 \mathrm{H}, \mathrm{ArH}), 5.23\left(\mathrm{~d}, 0.8 \mathrm{H}, J=12.9 \mathrm{~Hz}, \mathrm{OCH}_{2}\right.$ rotamer A), $5.14(\mathrm{~d}, 0.2 \mathrm{H}, J=$ $12.5 \mathrm{~Hz}, \mathrm{OCH}_{2}$ rotamer B), $5.07\left(\mathrm{~d}, 1 \mathrm{H}, J=13.0 \mathrm{~Hz}, \mathrm{OCH}_{2}\right), 3.84(\mathrm{dt}, 0.8 \mathrm{H}, J=12.5,3.4$ $\mathrm{Hz}, \mathrm{NCH}_{2}$ rotamer A), $3.71\left(\mathrm{~m}, 0.2 \mathrm{H}, \mathrm{NCH}_{2}\right.$, rotamer B), $3.64\left(\mathrm{~s}, 0.6 \mathrm{H}, \mathrm{OCH}_{3}\right.$ rotamer B), 3.58-3.52 (m, $2.4 \mathrm{H}, \mathrm{OCH}_{3}$ rotamer A and $\mathrm{NCH}$ rotamer $\left.\mathrm{B}\right), 3.49(\mathrm{~d}, 0.8 \mathrm{H}, J=3.7 \mathrm{~Hz}, \mathrm{NCH}$ rotamer A), $3.15\left(\mathrm{~s}, 0.6 \mathrm{H}, \mathrm{NCH}_{3}\right.$ rotamer $\left.\mathrm{B}\right), 3.12\left(\mathrm{~s}, 2.4 \mathrm{H}, \mathrm{NCH}_{3}\right.$ rotamer $\left.\mathrm{A}\right), 2.73(\mathrm{t}, 0.2 \mathrm{H}$, $J=11.7 \mathrm{~Hz}, \mathrm{NCH}_{2}$ rotamer B), $2.64\left(\mathrm{dt}, 0.8 \mathrm{H}, J=12.5,2.2 \mathrm{~Hz}, \mathrm{NCH}_{2}\right.$ rotamer A), 2.09-1.87 $\left(\mathrm{m}, 2 \mathrm{H}, \mathrm{CHCO}\right.$ and $\left.\mathrm{CH}_{2}\right), 1.77-1.54\left(\mathrm{~m}, 4 \mathrm{H}, \mathrm{CH}_{2}\right), 1.36\left(\mathrm{~m}, 1 \mathrm{H}, \mathrm{CH}_{2}\right), 0.85(\mathrm{t}, 3 \mathrm{H}, J=7.4$ $\left.\mathrm{Hz}, \mathrm{CH}_{3}\right) .{ }^{13} \mathrm{C} \mathrm{NMR}\left(\mathrm{CDCl}_{3}, 100 \mathrm{MHz}\right) \delta$ (rotamers!) 171.2, 156.2, 136.8, 128.2, 128.1, 127.8, 127.8, 127.4, 127.0, 66.8, 66.5, 61.2, 42.9, 42.7, 41.5, 41.0, 33.0, 32.4, 29.1, 28.5, 26.0, 25.9, 25.2, 21.6, 10.3. The values of the NMR spectra are in accordance with reported literature data. ${ }^{2}$

\section{Benzyl 7-(5,6-dimethoxy-1H-indole-2-carbonyl)-6-ethyl-2-azabicyclo[4.1.0]heptane-2- carboxylate (7)}<smiles>COc1cc2cc[nH]c2cc1OC</smiles>

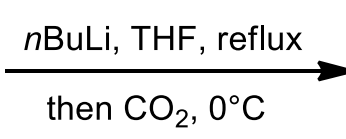

9<smiles>COc1cc2ccn(C(=O)O)c2cc1OC</smiles>

11

Following a slight modification of a reported procedure, ${ }^{7}$ commercially available 5,6dimethoxyindole $(9,180 \mathrm{mg}, 1.02 \mathrm{mmol}, 1.00 \mathrm{eq}$.) was dissolved in dry THF (7.0 mL). The colorless solution was cooled to $0{ }^{\circ} \mathrm{C}$ and a $1.6 \mathrm{M}$ solution of $n \mathrm{BuLi}$ in hexane $(760 \mu \mathrm{L}, 1.22$ mmol, 1.10 eq.) was added dropwise. The reaction mixture was heated at reflux for 2 hours and then cooled back to $0{ }^{\circ} \mathrm{C}$ to bubble $\mathrm{CO}_{2}$ into the reaction mixture for 45 minutes. The resulting suspension was quenched with water $(10 \mathrm{~mL})$ at $0{ }^{\circ} \mathrm{C}$ and extracted with diethyl ether $(3 \times 10 \mathrm{~mL})$. The combined organic layers were washed with water $(20 \mathrm{~mL})$. The

\footnotetext{
${ }^{6}$ M. Kunishima, C. Kawachi, F. Iwasaki, K. Terao, S. Tani, Tetrahedron Lett. 1999, 40, 5327-5330.

${ }^{7}$ D. A. Shirley, P. A. Roussel, J. Am. Chem. Soc. 1953, 75, 375-378.
} 
combined aqueous layers were acidified with $1.0 \mathrm{M}$ aq. $\mathrm{HCl}$ to $\mathrm{pH}=2$, followed by extraction with diethyl ether $(3 \times 15 \mathrm{~mL})$. The three combined diethyl ether layers were dried over $\mathrm{MgSO}_{4}$, filtered and concentrated in vacuo (for only five minutes to avoid potential decarboxylation) to yield carboxylic acid protected indole 11 (224 $\mathrm{mg}, 1.01 \mathrm{mmol}$, quant.) as a white solid, which was used in the next step without any further purification. ${ }^{1} \mathrm{H}$ NMR $\left(\mathrm{CDCl}_{3}, 400 \mathrm{MHz}\right) \delta 7.80(\mathrm{~s}, 1 \mathrm{H}, \mathrm{ArH}), 7.53(\mathrm{~d}, 1 \mathrm{H}, J=3.7 \mathrm{~Hz}, \mathrm{ArH}), 7.04(\mathrm{~s}, 1 \mathrm{H}, \mathrm{ArH})$, $6.57(\mathrm{~d}, 1 \mathrm{H}, J=3.6 \mathrm{~Hz}, \mathrm{ArH}), 4.00\left(\mathrm{~s}, 3 \mathrm{H}, \mathrm{OCH}_{3}\right), 3.95\left(\mathrm{~s}, 3 \mathrm{H}, \mathrm{OCH}_{3}\right) .{ }^{13} \mathrm{C} \mathrm{NMR}\left(\mathrm{CDCl}_{3}\right.$, $100 \mathrm{MHz}) \delta 155.7,148.2,147.1,129.5,124.2,123.6,109.5,102.9,99.5,56.5,56.3$.

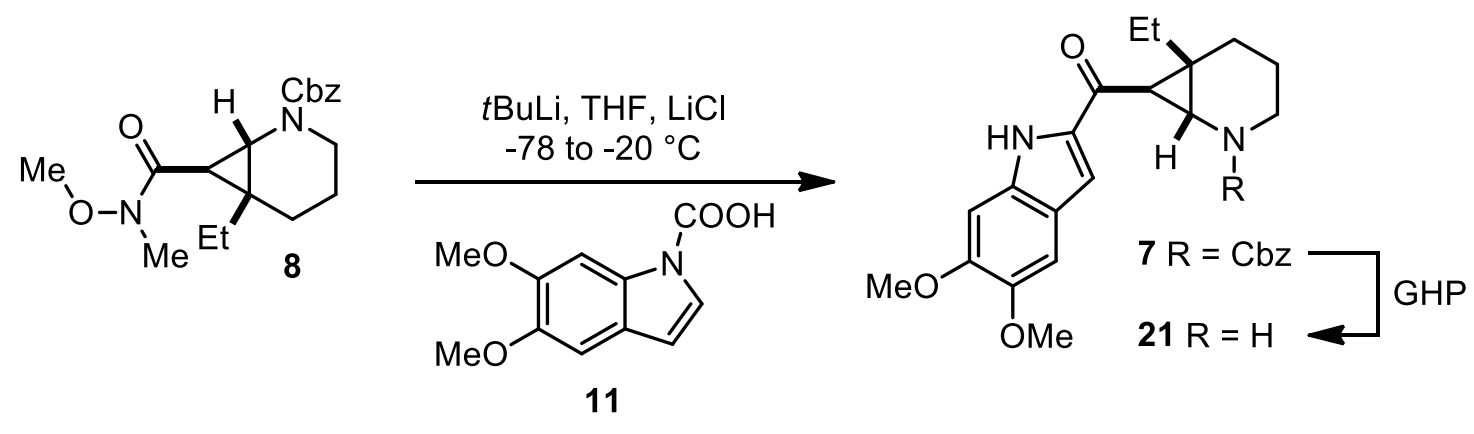

A $1.6 \mathrm{M}$ solution of $t \mathrm{BuLi}$ in pentane $(6.95 \mathrm{~mL}, 11.1 \mathrm{mmol}, 2.20$ eq.) was added dropwise to a solution of freshly prepared carboxylic acid protected indole 11 (1.23 g, $5.56 \mathrm{mmol}, 1.10$ eq.) and lithium chloride ${ }^{8}(236 \mathrm{mg}, 5.56 \mathrm{mmol}, 1.10$ eq. $)$ in dry THF $(26 \mathrm{~mL})$ at $-78{ }^{\circ} \mathrm{C}$. The mixture was stirred for 3 hours at $-78{ }^{\circ} \mathrm{C}$ and then transferred via cannula into a, to $78{ }^{\circ} \mathrm{C}$ precooled, solution of Weinreb-amide 8 (1.77 g, $5.11 \mathrm{mmol}, 1.00$ eq.) dissolved in dry THF (13 $\mathrm{mL}$ ). The reaction mixture was slowly allowed to warm up to $-20{ }^{\circ} \mathrm{C}$ over a 3.5 hour time period and then kept at $-20{ }^{\circ} \mathrm{C}$ for 30 minutes. The reaction was quenched by transferring it via cannula to saturated aq. $\mathrm{NaHCO}_{3}(75 \mathrm{~mL})$ pre-cooled to $0{ }^{\circ} \mathrm{C}$. The mixture was stirred for 10 minutes at $0{ }^{\circ} \mathrm{C}$, after which the ice/water bath was removed and stirring was continued for an additional 20 minutes. The aqueous mixture was extracted with diethyl ether $(4 \times 50 \mathrm{~mL})$ and the combined organic layers were dried over $\mathrm{MgSO}_{4}$, filtered and treated with deactivated silica gel prior to removing the solvent in vacuo. The crude product was purified by flash column chromatography (pentane:EtOAc 4:1 to 3:1), dry loading the crude, affording 7 (1.69 $\mathrm{g}, 3.65 \mathrm{mmol}, 72 \%)$ as a colorless oil ( $\mathrm{R}_{f}$ in pentane:EtOAc 7:3 =0.64). As NMR analysis of 7 was difficult due to the rotamers caused by the Cbz-protecting group, the above described general hydrogenolysis procedure (GHP) was utilized on a small aliquot of 7 to yield free amine 21 for a simplified compound analysis of the resulting light yellow oil. $\mathrm{R}_{f}$ (DCM:Ultra $4: 1)=0.57 .{ }^{1} \mathrm{H}$ NMR $\left(\mathrm{CD}_{2} \mathrm{Cl}_{2}, 400 \mathrm{MHz}\right): \delta 7.10(\mathrm{bs}, 1 \mathrm{H}, \mathrm{NH}), 7.07(\mathrm{~s}, 1 \mathrm{H}, \mathrm{ArH}), 6.79(\mathrm{~s}, 1$ $\mathrm{H}, \mathrm{ArH}), 4.87(\mathrm{~s}, 1 \mathrm{H}, \mathrm{ArH}), 3.94\left(\mathrm{~s}, 3 \mathrm{H}, \mathrm{OCH}_{3}\right), 3.86\left(\mathrm{~s}, 3 \mathrm{H}, \mathrm{OCH}_{3}\right), 3.27(\mathrm{~d}, 1 \mathrm{H}, J=17.0$ $\mathrm{Hz}, \mathrm{NHCH}), 3.16-3.08$ (m, $\left.1 \mathrm{H}, \mathrm{NHCH}_{2}\right), 2.90$ (td, $\left.1 \mathrm{H}, J=11.8,2.7 \mathrm{~Hz}, \mathrm{NHCH}_{2}\right), 2.21$ (d, 1 $\mathrm{H}, J=17.2 \mathrm{~Hz}, \mathrm{COCH}), 1.82-1.55(\mathrm{~m}, 4 \mathrm{H}) 1.42-1.21(\mathrm{~m}, 3 \mathrm{H}), 0.81(\mathrm{t}, 3 \mathrm{H}, J=7.5 \mathrm{~Hz}$, $\left.\mathrm{CH}_{2} \mathrm{CH}_{3}\right) .{ }^{13} \mathrm{C}$ NMR $\left(\mathrm{CD}_{2} \mathrm{Cl}_{2}, 100 \mathrm{MHz}\right) \delta 189.9,151.6,147.3,132.6,132.0,120.9,105.8$, 103.7, 92.4, 71.3, 56.6, 56.5, 46.0, 41.0, 39.7, 33.6, 30.9, 22.4, 7.5. IR v $2935(\mathrm{w}), 2856(\mathrm{w})$, $1658(\mathrm{~m}), 1527(\mathrm{~s}), 1493(\mathrm{w}), 1464(\mathrm{w}), 1408$ (w), $1350(\mathrm{w}), 1318(\mathrm{w}), 1224(\mathrm{~s}), 1051(\mathrm{w})$. HRMS (ESI) $\mathrm{C}_{19} \mathrm{H}_{25} \mathrm{~N}_{2} \mathrm{O}_{3}{ }^{+}[\mathrm{M}+\mathrm{H}]^{+}$calc. $=329.1860 ;[\mathrm{M}+\mathrm{H}]^{+}$obs. $=329.1867$.

\footnotetext{
${ }^{8} \mathrm{LiCl}$ was dried under careful flame heating and high vacuum $(<0.05$ Torr $)$ before it was dissolved in dry THF.
} 
<smiles>CCC12CCCN(C(=O)OCc3ccccc3)[C@H]1C2C(=O)c1cc2cc(OC)c(OC)cc2[nH]1</smiles><smiles>[R]N1CCC[C@@]2(CC)CC(=O)c3[nH]c4cc(OC)c(OC)cc4c3[C@H]12</smiles>

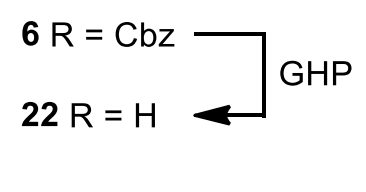

A $0.1 \mathrm{M}$ solution of copper(II) triflate in acetonitrile $(4.93 \mathrm{~mL}, 0.493 \mathrm{mmol}, 0.200 \mathrm{eq}$.) was slowly added at room temperature to a solution consisting of vinyl cyclopropyl ketone 7 (1.14 $\mathrm{g}, 2.47 \mathrm{mmol}, 1.00$ eq.) and dry acetonitrile $(120 \mathrm{~mL})$. The reaction mixture was stirred at room temperature for 10 minutes and then quenched by adding saturated aq. $\mathrm{NaHCO}_{3}(150$ $\mathrm{mL})$. The mixture was extracted with diethyl ether $(3 \times 50 \mathrm{~mL})$. The combined organic layers were washed with brine $(75 \mathrm{~mL})$, dried over $\mathrm{MgSO}_{4}$, filtered and concentrated in vacuo. The crude product was purified by flash column chromatography (pentane:EtOAc 3:1 to 2:1) to afford $6(971 \mathrm{mg}, 2.10 \mathrm{mmol}, 85 \%)$ as a light yellow solid $\left(\mathrm{R}_{f}\right.$ in pentane:EtOAc 1:1 = 0.50). As NMR analysis of $\mathbf{6}$ was difficult due to the rotamers caused by the Cbz-protecting group, the above described general hydrogenolysis procedure (GHP) was utilized on a small aliquot of $\mathbf{6}$ to yield free amine $\mathbf{2 2}$ for a simplified compound analysis resulting light yellow oil. $\mathrm{R}_{f}$ (DCM:Ultra 3:2) = 0.54. ${ }^{1} \mathrm{H}$ NMR $\left(\mathrm{CD}_{2} \mathrm{Cl}_{2}, 400 \mathrm{MHz}\right): \delta 9.24$ (bs, $1 \mathrm{H}, \mathrm{NH}$ indole), 7.15 (s, 1 $\mathrm{H}, \operatorname{Ar} H), 6.83(\mathrm{~s}, 1 \mathrm{H}, \mathrm{ArH}), 3.98(\mathrm{~s}, 1 \mathrm{H}, \mathrm{NCH}), 3.88\left(\mathrm{~s}, 3 \mathrm{H}, \mathrm{OCH}_{3}\right), 3.87\left(\mathrm{~s}, 3 \mathrm{H}, \mathrm{OCH}_{3}\right)$, $3.07\left(\mathrm{~d}, 1 \mathrm{H}, J=16.7 \mathrm{~Hz}, \mathrm{COCH}_{2}\right), 3.02-2.93\left(\mathrm{~m}, 1 \mathrm{H}, \mathrm{NHCH}_{2}\right), 2.86-2.74\left(\mathrm{~m}, 1 \mathrm{H}, \mathrm{NHCH}_{2}\right)$, $2.21\left(\mathrm{~d}, 1 \mathrm{H}, J=16.6 \mathrm{~Hz}, \mathrm{COCH}_{2}\right), 1.77-1.57$ (m, $\left.4 \mathrm{H}\right), 1.56-1.45(\mathrm{~m}, 2 \mathrm{H}), 1.40-1.29$ (m, 1 $\mathrm{H}), 0.81\left(\mathrm{t}, 3 \mathrm{H}, J=7.5 \mathrm{~Hz}, \mathrm{CH}_{2} \mathrm{CH}_{3}\right) .{ }^{13} \mathrm{C} \mathrm{NMR}\left(\mathrm{CD}_{2} \mathrm{Cl}_{2}, 100 \mathrm{MHz}\right) \delta 190.3,151.8,146.9$, 134.3, 130.1, 129.1, 119.2, 101.9, 94.8, 57.0, 56.6, 56.4, 45.8, 43.3, 41.2, 33.4, 31.4, 23.3, 8.0. IR v $3271(\mathrm{w}), 2934$ (w), 1644 (s), 1627 (s), 1539 (m), 1488 (s), 1463 (m), 1296 (w), 1266 (s), $1220(\mathrm{~s}), 1162(\mathrm{w}), 1012(\mathrm{w}) . \mathrm{HRMS}(\mathrm{ESI}) \mathrm{C}_{19} \mathrm{H}_{25} \mathrm{~N}_{2} \mathrm{O}_{3}{ }^{+}[\mathrm{M}+\mathrm{H}]^{+}$calc. $=329.1860 ;[\mathrm{M}+\mathrm{H}]^{+}$ obs. $=329.1865$.

(4,11)-benzyl 4-ethyl-9,10-dimethoxy-2,3,4,5,6,7,11-octahydro-1H-pyrido[3,2-]carbazole1-carboxylate (13)<smiles>CCC12CCCN(C(=O)O)[C@H]1c1c([nH]c3cc(OC)c(OC)cc13)C(=O)C2</smiles>

6

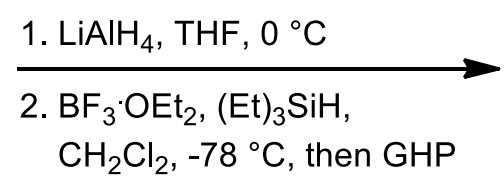

$\mathrm{CH}_{2} \mathrm{Cl}_{2},-78{ }^{\circ} \mathrm{C}$, then GHP<smiles>CCC12CCCN(C(=O)O)C1c1c([nH]c3cc(OC)c(OC)cc13)CC2</smiles>

13

The Cbz-protected ketone starting material 6 (200 mg, $0.432 \mathrm{mmol}, 1.00$ eq.) was dissolved in dry THF (7 mL), cooled to $-78{ }^{\circ} \mathrm{C}$ and slowly transferred via cannula to a suspension of lithium aluminum hydride $\left(32.8 \mathrm{mg}, 0.865 \mathrm{mmol}, 2.00 \mathrm{eq}\right.$.) at $-78{ }^{\circ} \mathrm{C}$. The reaction mixture was stirred for 2 hours at $-78^{\circ} \mathrm{C}$, after which the dry ice/acetone bath was removed to stir the reaction for an additional two hours at room temperature. The mixture was cooled to $0{ }^{\circ} \mathrm{C}$ and quenched by carefully adding a few drops of water. The resulting mixture was filtered through 
a, with THF prewashed, pad of celite and concentrated in vacuo to yield the corresponding hydroxy derivative 12 as a white solid. ${ }^{9}$ Intermediate 12 was dissolved in dry DCM (10 mL) and cooled to $-78{ }^{\circ} \mathrm{C}$. To the clear colorless solution was added dropwise freshly distilled boron trifluoride diethyl etherate $(137 \mu \mathrm{L}, 0.519 \mathrm{mmol}, 1.2$ eq.) to produce a dark red solution, which was quickly treated with excess triethylsilane $(5.0 \mathrm{~mL})$. The reaction mixture was stirred at $-78{ }^{\circ} \mathrm{C}$ for 10 minutes and then quenched by transferring it via cannula to saturated aq. $\mathrm{NaHCO}_{3}(20 \mathrm{~mL})$ pre-cooled to $0{ }^{\circ} \mathrm{C}$. The mixture was stirred for 10 minutes at $0{ }^{\circ} \mathrm{C}$, after which the ice/water bath was removed and stirring was continued for an additional 20 minutes. The aqueous mixture was extracted with DCM (3 x $20 \mathrm{~mL})$ and the combined organic layers were dried over $\mathrm{MgSO}_{4}$, filtered and concentrated in vacuo. The crude product was purified by flash column chromatography (pentane:EtOAc 3:1 to 2:1) affording 13 (180 $\mathrm{mg}, 0.402 \mathrm{mmol}, 93 \%$ ) as a light beige solid. ${ }^{10} \mathrm{R}_{f}$ (pentane:EtOAc 3:2) $=0.36 .{ }^{1} \mathrm{H}$ NMR $\left(\mathrm{CDCl}_{3}, 400 \mathrm{MHz}\right): 7.63$ (bs, $0.6 \mathrm{H}, \mathrm{NH}$ rotamer A), 7.61 (bs, $0.4 \mathrm{H}, \mathrm{NH}$ rotamer B), 7.47$7.26(\mathrm{~m}, 5 \mathrm{H}, \mathrm{Ar} H), 6.81$ (s, $0.6 \mathrm{H}, \mathrm{Ar} H$ rotamer A), 6.80 (s, $0.4 \mathrm{H}, \mathrm{Ar} H$ rotamer B), 6.70 (s, $0.4 \mathrm{H}, \mathrm{ArH}$ rotamer B), $6.68\left(\mathrm{~s}, 0.6 \mathrm{H}, \mathrm{ArH}\right.$ rotamer A), 5.41-5.16 (m, $3 \mathrm{H}, \mathrm{OCH}_{2}$ and $\left.\mathrm{NCH}\right)$, 4.15-4.07 $\left(\mathrm{m}, 0.6 \mathrm{H}\right.$ rotamer A), 4.07-3.99 $(\mathrm{m}, 0.4 \mathrm{H}$ rotamer $\mathrm{B}), 3.88\left(\mathrm{~s}, 1.8 \mathrm{H}, \mathrm{OCH}_{3}\right.$ rotamer $\mathrm{A}), 3.87\left(\mathrm{~s}, 1.2 \mathrm{H}, \mathrm{OCH}_{3}\right.$ rotamer $\left.\mathrm{B}\right), 3.64\left(\mathrm{~s}, 1.8 \mathrm{H}, \mathrm{OCH}_{3} \operatorname{rotamer} \mathrm{A}\right), 3.59(\mathrm{~s}, 1.2 \mathrm{H}$, $\mathrm{OCH}_{3}$ rotamer B), 2.81-2.69 (m, $\left.1 \mathrm{H}\right), 2.69-2.58(\mathrm{~m}, 1 \mathrm{H}), 2.57-2.46(\mathrm{~m}, 1 \mathrm{H}), 1.86-1.24(\mathrm{~m}, 8$ $\mathrm{H}), 0.92\left(\mathrm{t}, 1.2 \mathrm{H}, J=7.5 \mathrm{~Hz}, \mathrm{OCH}_{3}\right.$ rotamer B), $0.86\left(\mathrm{t}, 1.8 \mathrm{H}, J=7.5 \mathrm{~Hz}, \mathrm{OCH}_{3}\right.$ rotamer A). HRMS (ESI) $\mathrm{C}_{27} \mathrm{H}_{33} \mathrm{~N}_{2} \mathrm{O}_{4}{ }^{+}[\mathrm{M}+\mathrm{H}]^{+}$calc. $=449.2435 ;[\mathrm{M}+\mathrm{H}]^{+}$obs. $=449.2437$.

\section{3-Ethyl-8,9-dimethoxy-2,3,3,4,5,11,12-octahydro-1H-indolizino[8,1]carbazole (14)}

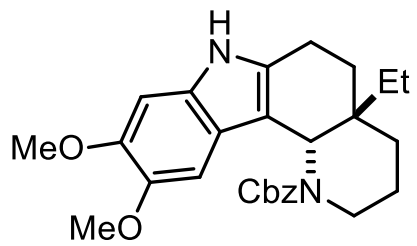

13
1. GHP, then $\mathrm{Na}_{2} \mathrm{CO}_{3}, \mathrm{MeOH}$ $\mathrm{BrCH}_{2} \mathrm{CH}_{2} \mathrm{OH}, 80^{\circ} \mathrm{C}$

2. $\mathrm{MsCl}, \mathrm{Et}_{3} \mathrm{~N}, \mathrm{CH}_{2} \mathrm{Cl}_{2},-20^{\circ} \mathrm{C}$

3. $\mathrm{KO}^{\mathrm{t}} \mathrm{Bu}, \mathrm{THF}, \mathrm{rt}$

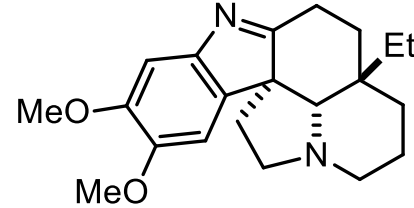

14

A Schlenk tube was charged under nitrogen with intermediate $13(20.0 \mathrm{mg}, 0.0446 \mathrm{mmol}$, 1.00 eq.) and the above described GHP was carried out for Cbz-group removal. The reaction was monitored by HPLC-MS, which indicated full deprotection $\left([\mathrm{M}+\mathrm{H}]^{+}\right.$calc. $=315.2607$; $[\mathrm{M}+\mathrm{H}]^{+}$obs. $\left.=315.2603\right)$ after 15 minutes of stirring at room temperature. The Pd-catalyst was quickly removed via filtration through a CHROMAFIL ${ }^{\circledR}$ Xtra RC-20/25 syringe filter. After washing the filter several times with dry ethanol, the solvent was removed in vacuo. Following a slight modification of a reported procedure, ${ }^{11}$ the free amine was immediately dissolved in dry methanol $(2.0 \mathrm{~mL})$ in a Schlenk tube under nitrogen. To the resulting solution was added 2-bromoethanol (31.6 $\mu \mathrm{L}, 0.446 \mathrm{mmol}, 10.0$ eq.) and dry sodium carbonate (47.0 $\mathrm{mg}, 0.446 \mathrm{mmol}, 10.0$ eq.). The sealed Schlenk tube was stirred at reflux and the reaction was monitored by HPLC-MS. The free amine was consumed after 4 hours and HPLC-MS analysis indicated the desired alkylation as the main product $\left(\mathrm{HRMS}:[\mathrm{M}+\mathrm{H}]^{+}\right.$calc. $=359.2329$; $[\mathrm{M}+\mathrm{H}]^{+}$obs. $\left.=359.2338\right)$. Thus, the solvent was removed in vacuo and the resulting light yellow solid (still in the Schlenk tube) was dissolved in dry DCM (2.0 mL) and cooled to -20

\footnotetext{
9 The full characterization of one of the two formed hydroxy diastereoisomer (12a) is shown below for the transformation $\mathbf{6}$ to $\mathbf{1 5 .}$

${ }^{10} \mathrm{We}$ observed that intermediate $\mathbf{1 3}$ decomposed quickly, even at $-20{ }^{\circ} \mathrm{C}$ and under argon, and should be used immediately for a subsequent transformation.

${ }^{11}$ S. A. Kozmin, T. Iwama, Y. Huang, V. H. Rawal, J. Am. Chem. Soc. 2002, 124, 4628-4641.
} 
${ }^{\circ} \mathrm{C}$. The solution was treated with methanesulfonyl chloride $(6.90 \mu \mathrm{L}, 0.0891 \mathrm{mmol}, 2.00 \mathrm{eq}$.$) ,$ triethylamine $(18.7 \mu \mathrm{L}, 0.134 \mathrm{mmol}, 3.00$ eq.) and then slowly let come to room temperature over a 3 hour time period. HPLC-MS analysis indicated formation of the 2chloroethylamine $^{12}$ alkylation product $\left(\mathrm{HRMS}:[\mathrm{M}+\mathrm{H}]^{+}\right.$calc. $=377.1990 ;[\mathrm{M}+\mathrm{H}]^{+}$obs. $=$ 377.2009) as well as some already cyclized product $14\left(\mathrm{HRMS}:[\mathrm{M}+\mathrm{H}]^{+}\right.$calc. $=341.2224$; $[\mathrm{M}+\mathrm{H}]^{+}$obs. $\left.=341.2238\right)$. In order to cyclize the remaining chloroethylamine intermediate, the mixture was concentrated in vacuo, the resulting yellow solid suspended in dry THF (4.0 $\mathrm{mL}$ ) and cooled to $0{ }^{\circ} \mathrm{C}$. Next was added dropwise at $0{ }^{\circ} \mathrm{C}$ a $0.3 \mathrm{M}$ potassium tert.-butoxide solution in THF $(0.300 \mathrm{~mL}, 0.0892 \mathrm{mmol}, 2.00 \mathrm{eq}$.) and the mixture was stirred overnight for 16 hours, letting the reaction temperature slowly come to room temperature. HPLC-MS analysis indicated full consumption of the remaining chloroethylamine intermediate. Thus, the reaction mixture was quenched by adding a few drops of water, diluted with THF $(5.0 \mathrm{~mL})$, dried over $\mathrm{MgSO}_{4}$, filtered and concentrated in vacuo. Attempts to purify the crude product by column chromatography or crystallization were unsuccessful as the product quickly decomposed into numerous unidentifiable products during these purification efforts.

\section{Methyl 4-ethyl-1-(2-hydroxyethyl)-9,10-dimethoxy-2,3,4,5,6,7,11-octahydro-1H- pyrido[3,2]carbazole-6-carboxylate (15)}

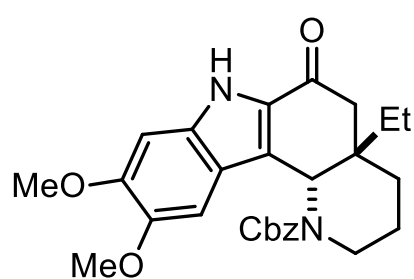

6
1. $\mathrm{LiAlH}_{4}, \mathrm{THF}, 0{ }^{\circ} \mathrm{C}$

2. $\mathrm{BF}_{3} \cdot \mathrm{OEt}_{2},(\mathrm{Me})_{3} \mathrm{SiCN}$, $\mathrm{CH}_{2} \mathrm{Cl}_{2},-78^{\circ} \mathrm{C}$

3. $\mathrm{HCl}, \mathrm{MeOH}$, then $\mathrm{H}_{2} \mathrm{O}$ and $\mathrm{GHP}$

4. $\mathrm{Na}_{2} \mathrm{CO}_{3}, 2$-bromoethanol $\mathrm{MeOH}$, reflux<smiles>CCC12CCCN(CCO)C1c1c([nH]c3cc(OC)c(OC)cc13)[C@H](C(C)=O)C2</smiles>

The Cbz-protected ketone starting material $(6,435 \mathrm{mg}, 0.940 \mathrm{mmol}, 1.00 \mathrm{eq}$.$) was dissolved$ in dry THF (43 mL), cooled to $0{ }^{\circ} \mathrm{C}$ and slowly transferred via cannula to a suspension of lithium aluminum hydride $(71.4 \mathrm{mg}, 1.88 \mathrm{mmol}, 2.00$ eq. $)$ at $0{ }^{\circ} \mathrm{C}$. The reaction mixture was stirred overnight for 11 hours at $0{ }^{\circ} \mathrm{C}$ and then quenched by carefully adding a few drops of water. The mixture was filtered through a, with THF prewashed, pad of celite and concentrated in vacuo to yield the two corresponding hydroxy diastereoisomers $12(420 \mathrm{mg}$, $0.904 \mathrm{mmol}, 96 \%, \mathrm{R}_{f}$ in pentane:EtOAc $1: 1=0.48$ for $\mathbf{1 2 a}$ and 0.44 for $\mathbf{1 2 b}$ ) as a white solid. Intermediate 12 was stored under argon at $-20{ }^{\circ} \mathrm{C}$ and aliquots of it were used to investigate further transformations. We note that highly pure solvents, reagents and clean glassware are required for subsequent reactions utilizing 12, as in certain cases rapid decomposition of this sensitive intermediate was observed. It was possible to obtain a pure sample of hydroxy diastereoisomer 12a for characterization purposes by flash column chromatography (pentante:EtOAc 2:1). Partial degradation of sensitive hydroxy intermediate 12 was however observed during flash column chromatography purification.

Hydroxy diastereoisomers 12a: $\mathrm{R}_{f}$ (pentane:EtOAc 1:1) $=0.48 .{ }^{1} \mathrm{H} \mathrm{NMR}\left(\mathrm{CD}_{2} \mathrm{Cl}_{2}, 400 \mathrm{MHz}\right)$ : 8.55 (bs, $0.4 \mathrm{H}, \mathrm{N} H$ rotamer B), 8.53 (bs, $0.6 \mathrm{H}, \mathrm{NH}$ rotamer $\mathrm{A}), 7.47-7.23(\mathrm{~m}, 5 \mathrm{H}, \mathrm{ArH})$,

\footnotetext{
${ }^{12}$ The 2-chloroethylamine derivative is presumably formed by displacement of the initially formed mesylate by the proximate nucleophilic nitrogen atom of the piperidine ring, producing an aziridinium ion, which can be opened by the chloride ion.
} 
$6.80(\mathrm{~s}, 1 \mathrm{H}, \mathrm{Ar} H), 6.65$ (s, $0.4 \mathrm{H}, \mathrm{Ar} H$ rotamer B), 6.63 (s, $0.6 \mathrm{H}, \mathrm{Ar} H$ rotamer A), 5.34-5.16 $(\mathrm{m}, 3 \mathrm{H}), 4.95-4.88(\mathrm{~m}, 0.4 \mathrm{H}, \mathrm{NCH}$ rotamer $\mathrm{B}), 4.88-4.80(\mathrm{~m}, 0.6 \mathrm{H}$, rotamer $\mathrm{A}), 4.11-4.02$ $\left(\mathrm{m}, 0.4 \mathrm{H}, \mathrm{NCH}\right.$ rotamer B), 4.02-3.93 $\left(\mathrm{m}, 0.6 \mathrm{H}\right.$, rotamer A), $3.78\left(\mathrm{~s}, 3 \mathrm{H}, \mathrm{OCH}_{3}\right), 3.61$ (s, $1.3 \mathrm{H}, \mathrm{OCH}_{3}$ rotamer $\left.\mathrm{B}\right), 3.55\left(\mathrm{~s}, 1.7 \mathrm{H}, \mathrm{OCH}_{3}\right.$ rotamer $\left.\mathrm{A}\right), 2.52-2.37(\mathrm{~m}, 1 \mathrm{H}), 2.18-2.01(\mathrm{~m}$, $1 \mathrm{H}), 1.70-1.33(\mathrm{~m}, 6 \mathrm{H}), 1.31-1.18(\mathrm{~m}, 2 \mathrm{H}), 0.88\left(\mathrm{t}, 1.3 \mathrm{H}, J=7.5 \mathrm{~Hz}, \mathrm{OCH}_{3}\right.$ rotamer B), $0.78\left(\mathrm{t}, 1.3 \mathrm{H}, J=7.5 \mathrm{~Hz}, \mathrm{OCH}_{3}\right.$ rotamer A). ${ }^{13} \mathrm{C} \mathrm{NMR}\left(\mathrm{CD}_{2} \mathrm{Cl}_{2}, 100 \mathrm{MHz}\right) \delta$ (rotamers!) $156.6,147.6,147.5,145.5,145.4,137.7,135.8,135.2$, 129.0, 128.9, 128.5, 128.4, 119.1, $110.1,109.8,101.6,101.5,95.4,67.6,64.1,64.0,56.5,56.4,56.3,55.5,43.3,43.2,40.1,40.0$, 39.9, 39.8, 28.7, 28.5, 27.1, 26.7, 21.6, 21.2, 8.1, 8.0. IR $v 3368(\mathrm{w}), 2940(\mathrm{~m}), 2864(\mathrm{w})$, $1676(\mathrm{~s}), 1485$ (m), $1463(\mathrm{~m}), 1434$ (s), 1320 (m), 1210 (s), 1157 (m), $1113(\mathrm{~m}), 1027(\mathrm{w})$, $757(\mathrm{w}) . \mathrm{HRMS}(\mathrm{ESI}) \mathrm{C}_{27} \mathrm{H}_{33} \mathrm{~N}_{2} \mathrm{O}_{5}{ }^{+}[\mathrm{M}+\mathrm{H}]^{+}$calc. $=465.2384 ;[\mathrm{M}+\mathrm{H}]^{+}$obs. $=465.2387$.

Hydroxy intermediate 12 (23.0 mg, $0.0495 \mathrm{mmol}, 1.00$ eq.) was dissolved in freshly distilled DCM $(2.0 \mathrm{~mL})$ and cooled to $-78{ }^{\circ} \mathrm{C}$. To the clear colorless solution was added dropwise freshly distilled boron trifluoride diethyl etherate ${ }^{13}(8 \mu \mathrm{L}, 0.06 \mathrm{mmol}, 1.2$ eq. $)$ to produce a dark red solution, which was quickly treated with freshly distilled trimethylsilyl cyanide (20 $\mu \mathrm{L}, 0.15 \mathrm{mmol}, 3.0$ eq.). The reaction mixture was stirred at $-78{ }^{\circ} \mathrm{C}$ for 5 minutes and then quickly transferred via cannula to saturated aq. $\mathrm{NaHCO}_{3}(10 \mathrm{~mL})$ pre-cooled to $0{ }^{\circ} \mathrm{C}$. The mixture was extracted with DCM $(3 \times 10 \mathrm{~mL})$ and the combined organic layers were dried over $\mathrm{MgSO}_{4}$, filtered and concentrated in vacuo. The crude product was purified by flash column chromatography (hexane:EtOAc 3:2) to afford the cyano intermediate $(22.2 \mathrm{mg}$, 0.0469 mmol, 95\%, $\mathrm{R}_{f}$ in EtOAc:Hexane 1:1 = 0.38, HRMS: $[\mathrm{M}+\mathrm{H}]^{+}$calc. $=474.2387$; $[\mathrm{M}+\mathrm{H}]^{+}$obs. $\left.=474.2382\right)$ as a colorless oil, which was immediately used for subsequent transformations.

The cyano intermediate $(15.6 \mathrm{mg}, 0.0329 \mathrm{mmol}, 1.00$ eq.) was dissolved in freshly distilled methanol $(70 \mu \mathrm{L})$ and cooled to $0{ }^{\circ} \mathrm{C}$ at which $4.0 \mathrm{M} \mathrm{HCl}$ in cyclopentyl methyl ether $(830$ $\mu \mathrm{L}$ ) was added dropwise. The reaction mixture was stirred overnight for 12 hours at $0{ }^{\circ} \mathrm{C}$, followed by hydrolyzing the corresponding Pinner salt by slowly adding water $(10 \mathrm{~mL})$ at 0 ${ }^{\circ} \mathrm{C}$. The resulting mixture was stirred for 60 minutes at room temperature and extracted with DCM $(3 \times 10 \mathrm{~mL})$. The combined organic layers were dried over $\mathrm{MgSO}_{4}$, filtered and concentrated in vасио. The crude product was purified by flash column chromatography (hexane:EtOAc 3:1) to afford the pure Cbz-protected methyl ester intermediate $\left(\mathrm{R}_{f}\right.$ in EtOAc:Hexane 3:2 = 0.53, HRMS: $[\mathrm{M}+\mathrm{H}]^{+}$calc. $=507.2490 ;[\mathrm{M}+\mathrm{H}]^{+}$obs. $\left.=507.2494\right)$, which was subsequently subjected to the general hydrogenolysis procedure giving the highly reactive free secondary amine $\left(10.8 \mathrm{mg}, 0.0290 \mathrm{mmol}, 88 \%\right.$, HRMS: $[\mathrm{M}+\mathrm{H}]^{+}$calc. $=$ 373.2122; $[\mathrm{M}+\mathrm{H}]^{+}$obs. $\left.=373.2119\right)$ as a light yellow oil. ${ }^{14}$

Following a slight modification of a reported procedure, ${ }^{11}$ the free secondary amine $(40.6 \mathrm{mg}$, $0.109 \mathrm{mmol}, 1.00$ eq.) was dissolved in freshly distilled methanol $(9.0 \mathrm{~mL})$ in a Schlenk tube under nitrogen. The resulting solution was charged at room temperature under nitrogen with freshly distilled 2-bromoethanol $(77.0 \mu \mathrm{L}, 1.09 \mathrm{mmol}, 10.0 \mathrm{eq}$.$) and dry sodium carbonate$ (115 mg, $1.09 \mathrm{mmol}, 10.0$ eq.). The reaction mixture was stirred at reflux overnight for 12 hours in the sealed Schlenk tube, after which the solvent was removed in vacuo. The crude was extracted with water $(10 \mathrm{~mL})$ and DCM $(3 \times 10 \mathrm{~mL})$. The combined organic layers were dried over $\mathrm{MgSO}_{4}$, filtered and concentrated in vacuo. The crude product was purified by flash column chromatography (DCM:Ultra 97:3) to afford alkylation product 15 (42.2 $\mathrm{mg}$, $0.101 \mathrm{mmol}, 93 \%, 78 \%$ overall from 12) as a light yellow oil. $\mathrm{R}_{f}(\mathrm{DCM}$ :Ultra $7: 3)=0.51 .{ }^{1} \mathrm{H}$

\footnotetext{
${ }^{13} \mathrm{InCl}_{3}$ can be used as an alternative as it produced comparable results.

${ }^{14} \mathrm{NMR}$ analysis was unfeasible as the compound readily decomposed as solution in $\mathrm{CD}_{2} \mathrm{Cl}_{2}$.
} 
NMR ( $\left.\mathrm{CD}_{2} \mathrm{Cl}_{2}, 400 \mathrm{MHz}\right): 8.31$ (bs, $\left.1 \mathrm{H}, \mathrm{NH}\right), 6.90$ (s, $\left.1 \mathrm{H}, \mathrm{ArH}\right), 6.87$ (s, $\left.1 \mathrm{H}, \operatorname{ArH}\right), 3.85$ (s, $\left.3 \mathrm{H}, \mathrm{OCH}_{3}\right), 3.84\left(\mathrm{~s}, 3 \mathrm{H}, \mathrm{OCH}_{3}\right), 3.83-3.78(\mathrm{~m}, 1 \mathrm{H}), 3.77\left(\mathrm{~s}, 3 \mathrm{H}, \mathrm{CO}_{2} \mathrm{CH}_{3}\right), 3.45$ (td, $1 \mathrm{H}, J$ $=10.3,3.1 \mathrm{~Hz}), 3.17(\mathrm{~s}, 1 \mathrm{H}, \mathrm{NCH}), 3.14-2.93(\mathrm{~m}, 5 \mathrm{H}), 2.26-2.15(\mathrm{~m}, 2 \mathrm{H}), 1.97-1.82(\mathrm{~m}, 1$ H), 1.81-1.72 (m, $1 \mathrm{H}), 1.68-1.55(\mathrm{~m}, 2 \mathrm{H}), 1.45(\mathrm{td}, 1 \mathrm{H}, J=13.6,4.8 \mathrm{~Hz}), 1.19-1.08(\mathrm{~m}, 1$

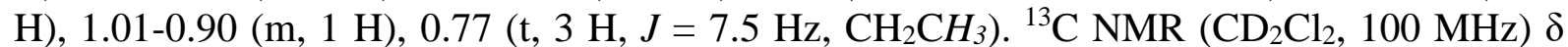
174.0, 147.6, 145.9, 130.9, 129.5, 122.5, 113.0, 101.4, 95.6, 63.2, 58.7, 57.0, 56.7, 55.1, 52.9, 52.9, 39.3, 38.6, 34.9, 30.4, 28.1, 22.4, 8.1. IR v $3352(\mathrm{w}), 2936(\mathrm{w}), 2831$ (w), 1733 (s), 1486 (s), 1464 (m), 1295 (m), 1235 (m), 1201 (s), 1161 (s), 1121 (m), 1055 (w), 1034 (m), $956(\mathrm{w})$. HRMS (ESI) $\mathrm{C}_{23} \mathrm{H}_{33} \mathrm{~N}_{2} \mathrm{O}_{5}{ }^{+}[\mathrm{M}+\mathrm{H}]^{+}$calc. $=417.2384 ;[\mathrm{M}+\mathrm{H}]^{+}$obs. $=417.2381$.

\section{Methyl 3-ethyl-8,9-dimethoxy-2,3,4,6,11,12-octahydro-1H-indolizino[8,1]carbazole-5- carboxylate (16)}<smiles>CCC12CCCN(CCO)C1c1c([nH]c3cc(OC)c(OC)cc13)C(C(C)=O)C2</smiles>

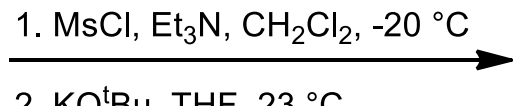

2. $\mathrm{KO}{ }^{\mathrm{t} B u}, \mathrm{THF}, 23^{\circ} \mathrm{C}$

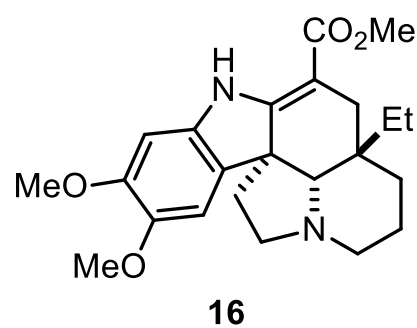

16

Following a slight modification of a reported procedure, ${ }^{11}$ primary alcohol $15(40.1 \mathrm{mg}$, $0.0963 \mathrm{mmol}, 1.00$ eq.) was dissolved in dry DCM $(4.0 \mathrm{~mL})$ and cooled to $-20{ }^{\circ} \mathrm{C}$. The solution was treated with methanesulfonyl chloride $(15.0 \mu \mathrm{L}, 0.193 \mathrm{mmol}, 2.00$ eq.), triethylamine $\left(40.3 \mu \mathrm{L}, 0.289 \mathrm{mmol}, 3.00\right.$ eq.) and stirred at $-20{ }^{\circ} \mathrm{C}$ for 60 minutes. The reaction mixture was diluted with DCM $(10 \mathrm{~mL})$ and extracted with saturated aq. $\mathrm{NaHCO}_{3}$ $(10 \mathrm{~mL})$. The aqueous layer was extracted with additional portions of DCM $(2 \times 10 \mathrm{~mL})$ and the combined organic layers were dried over $\mathrm{MgSO}_{4}$, filtered and concentrated in vacuo. The resulting yellow oil was dissolved in dry THF $(4.0 \mathrm{~mL})$ and cooled to $0{ }^{\circ} \mathrm{C}$. Next was added dopwise at $0{ }^{\circ} \mathrm{C}$ a $0.3 \mathrm{M}$ potassium tert.-butoxide solution in THF $(1.60 \mathrm{~mL}, 0.481 \mathrm{mmol}, 5.00$ eq.) and the mixture was stirred overnight for 14 hours, letting the reaction temperature slowly come to room temperature. The reaction mixture was quenched by adding a few drops of water, diluted with THF $(5.0 \mathrm{~mL})$, dried over $\mathrm{MgSO}_{4}$, filtered and concentrated in vacuo. The crude product was purified by flash column chromatography (DCM:Ultra 98:2) to afford pentacyclic product $16(32.8 \mathrm{mg}, 0.0823 \mathrm{mmol}, 85 \%)$ as a light yellow oil. $\mathrm{R}_{f}$ (DCM:Ultra 4:1) = 0.56. ${ }^{1} \mathrm{H}$ NMR $\left(\mathrm{CD}_{2} \mathrm{Cl}_{2}, 400 \mathrm{MHz}\right): 8.75(\mathrm{bs}, 1 \mathrm{H}, \mathrm{NH}), 6.81(\mathrm{~s}, 1 \mathrm{H}, \mathrm{ArH}), 6.49$ (s, 1 $\mathrm{H}, \mathrm{ArH}), 3.79$ (s, $\left.6 \mathrm{H}, \mathrm{OCH}_{3}\right), 3.72\left(\mathrm{~s}, 3 \mathrm{H}, \mathrm{CO}_{2} \mathrm{CH}_{3}\right), 3.14-3.06(\mathrm{~m}, 1 \mathrm{H}), 2.93-2.86(\mathrm{~m}, 1 \mathrm{H})$, $2.69(\mathrm{~d}, 1 \mathrm{H}, J=14.9 \mathrm{~Hz}), 2.59-2.50(\mathrm{~m}, 1 \mathrm{H}), 2.45-2.36(\mathrm{~m}, 2 \mathrm{H}), 2.23$ (dd, $1 \mathrm{H}, J=15.1,2.0$ $\mathrm{Hz}), 1.99(\mathrm{td}, 1 \mathrm{H}, J=11.3,6.5 \mathrm{~Hz}), 1.88-1.74(\mathrm{~m}, 2 \mathrm{H}), 1.64(\mathrm{dd}, 1 \mathrm{H}, J=11.3,4.8, \mathrm{~Hz})$, 1.56-1.49 (m, $1 \mathrm{H}), 1.32-1.20(\mathrm{~m}, 1 \mathrm{H}), 1.02-0.93(\mathrm{~m}, 1 \mathrm{H}), 0.69-0.54(\mathrm{~m}, 4 \mathrm{H}) .{ }^{13} \mathrm{C} \mathrm{NMR}$ $\left(\mathrm{CD}_{2} \mathrm{Cl}_{2}, 100 \mathrm{MHz}\right) \delta 169.4,169.2,149.8,144.3,137.7,129.5,108.0,96.2,93.0,73.2,57.6$, 56.6, 56.3, 52.2, 51.3, 51.1, 45.7, 38.8, 33.5, 29.7, 25.9, 22.8, 7.5. IR v $3362(\mathrm{w}), 2934(\mathrm{~m})$, $2774(\mathrm{w}), 1674(\mathrm{~m}), 1615$ (s), 1498 (s), 1461 (m), 1291 (m), 1264 (s), 1204 (s), 1191 (s), 1164 (s), 1137 (s), $1115(\mathrm{~m}), 1048(\mathrm{~m})$. HRMS (ESI) $\mathrm{C}_{23} \mathrm{H}_{31} \mathrm{~N}_{2} \mathrm{O}_{4}{ }^{+}[\mathrm{M}+\mathrm{H}]^{+}$calc. = 399.2278; $[\mathrm{M}+\mathrm{H}]^{+}$obs. $=399.2286$. 

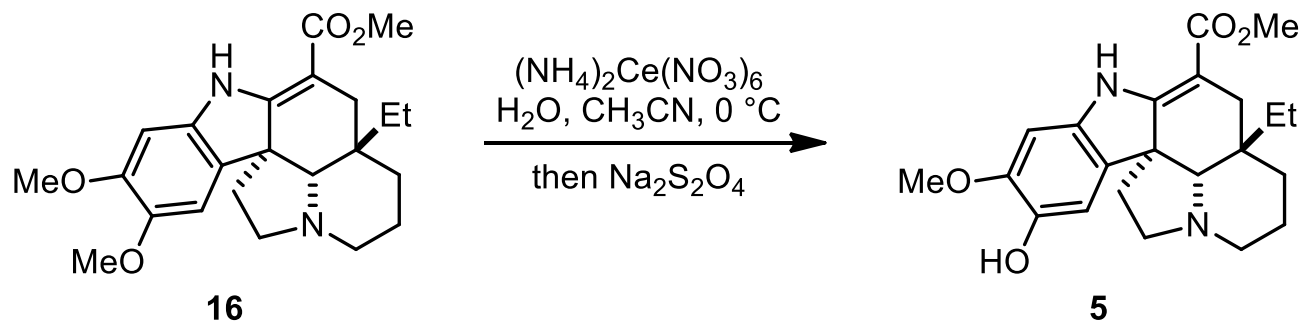

Dimethoxy starting material $16(15.0 \mathrm{mg}, 0.0376 \mathrm{mmol}, 1.00$ eq. $)$ was dissolved in acetonitrile $(1.5 \mathrm{~mL})$ and cooled to $0{ }^{\circ} \mathrm{C}$. To the mixture was slowly added a solution consisting of ceric ammonium nitrate $(45.4 \mathrm{mg}, 0.0830 \mathrm{mmol}, 2.20$ eq.) dissolved in water $(1.0 \mathrm{~mL})$ at $0{ }^{\circ} \mathrm{C}$. The reaction was stirred for 5 minutes at $0{ }^{\circ} \mathrm{C}$ and then poured into a $1.0 \mathrm{M}$ aq. sodium dithionite solution $(10 \mathrm{~mL})$ at $0{ }^{\circ} \mathrm{C}$. The reaction mixture was stirred for 10 minutes at $0{ }^{\circ} \mathrm{C}$, diluted with DCM $(10 \mathrm{~mL})$ and extracted. The aqueous layer was washed with additional portions of DCM $(3 \times 10 \mathrm{~mL})$. The combined organic layers were dried over $\mathrm{MgSO}_{4}$, filtered and concentrated in vacuo. The crude product was purified by flash column chromatography (DCM:Ultra 98:2) to afford jerantinine E (5, $11.4 \mathrm{mg}, 0.0297 \mathrm{mmol}, 79 \%)$ as a yellow oil. $\mathrm{R}_{f}(\mathrm{DCM}: U 1 t r a \mathrm{4}: 1)=0.48 .{ }^{1} \mathrm{H} \mathrm{NMR}\left(\mathrm{CDCl}_{3}, 400 \mathrm{MHz}\right): 8.76(\mathrm{bs}, 1 \mathrm{H}, \mathrm{NH})$, $6.83(\mathrm{~s}, 1 \mathrm{H}, \operatorname{Ar} H), 6.43(\mathrm{~s}, 1 \mathrm{H}, \operatorname{Ar} H), 5.27$ (bs, $1 \mathrm{H}, \mathrm{OH}), 3.86\left(\mathrm{~s}, 3 \mathrm{H}, \mathrm{OCH}_{3}\right), 3.75(\mathrm{~s}, 3 \mathrm{H}$, $\left.\mathrm{CO}_{2} \mathrm{CH}_{3}\right), 3.14-3.05(\mathrm{~m}, 1 \mathrm{H}), 2.94-2.85(\mathrm{~m}, 1 \mathrm{H}), 2.70(\mathrm{~d}, 1 \mathrm{H}, J=15.0 \mathrm{~Hz}), 2.58-2.47(\mathrm{~m}, 1$ H), 2.43-2.32 (m, $2 \mathrm{H}), 2.24(\mathrm{dd}, 1 \mathrm{H}, J=15.1,1.9 \mathrm{~Hz}), 2.03(\mathrm{td}, 1 \mathrm{H} . J=11.4,6.4 \mathrm{~Hz}), 1.88-$ $1.74(\mathrm{~m}, 2 \mathrm{H}), 1.66$ (dd, $1 \mathrm{H}, J=11.5,4.6, \mathrm{~Hz}), 1.57-1.48(\mathrm{~m}, 1 \mathrm{H}), 1.31-1.18(\mathrm{~m}, 1 \mathrm{H}), 1.02-$ $0.92(\mathrm{~m}, 1 \mathrm{H}), 0.68-0.54(\mathrm{~m}, 4 \mathrm{H}) .{ }^{13} \mathrm{C} \mathrm{NMR}\left(\mathrm{CD}_{2} \mathrm{Cl}_{2}, 100 \mathrm{MHz}\right) \delta 169.5,169.2,146.4$, 140.5, 136.8, 130.5, 108.9, 95.2, 92.9, 73.3, 56.9, 56.1, 52.1, 51.3, 51.2, 45.8, 38.9, 33.4, 29.7, 25.9, 22.9, 7.5. IR $v 3370(\mathrm{w}), 2934(\mathrm{w}), 2776(\mathrm{w}), 1671(\mathrm{~m}), 1606(\mathrm{~s}), 1494(\mathrm{~s}), 1441(\mathrm{~m})$, 1266 (s), 1196 (s), 1165 (s), 1136 (s), 1114 (m), 1047 (w). HRMS (ESI) $\mathrm{C}_{22} \mathrm{H}_{29} \mathrm{~N}_{2} \mathrm{O}_{4}{ }^{+}[\mathrm{M}+\mathrm{H}]^{+}$ calc. $=385.2122 ;[\mathrm{M}+\mathrm{H}]^{+}$obs. $=385.2113$.

As shown below in Figure S1, the ${ }^{1} \mathrm{H}$ NMR spectrum of synthesized jerantinine E is identical to the ${ }^{1} \mathrm{H}$ NMR spectrum of jerantinine E isolated from the Malayan plant Tabernaemontana corymbosa. ${ }^{15}$

\footnotetext{
${ }^{15}$ The isolation ${ }^{1} \mathrm{H}$ NMR spectrum of jerantinine E was kindly provided by Prof. T. S. Kam through a personal communication. The NMR data of isolated jerantinine $\mathrm{E}$ is summarized in the manuscript by Prof. Kam and coworkers: K. H. Lim, O. Hiraku, K. Komiyama, T. S. Kam, J. Nat. Prod. 2008, 71, 1591-1594.
} 


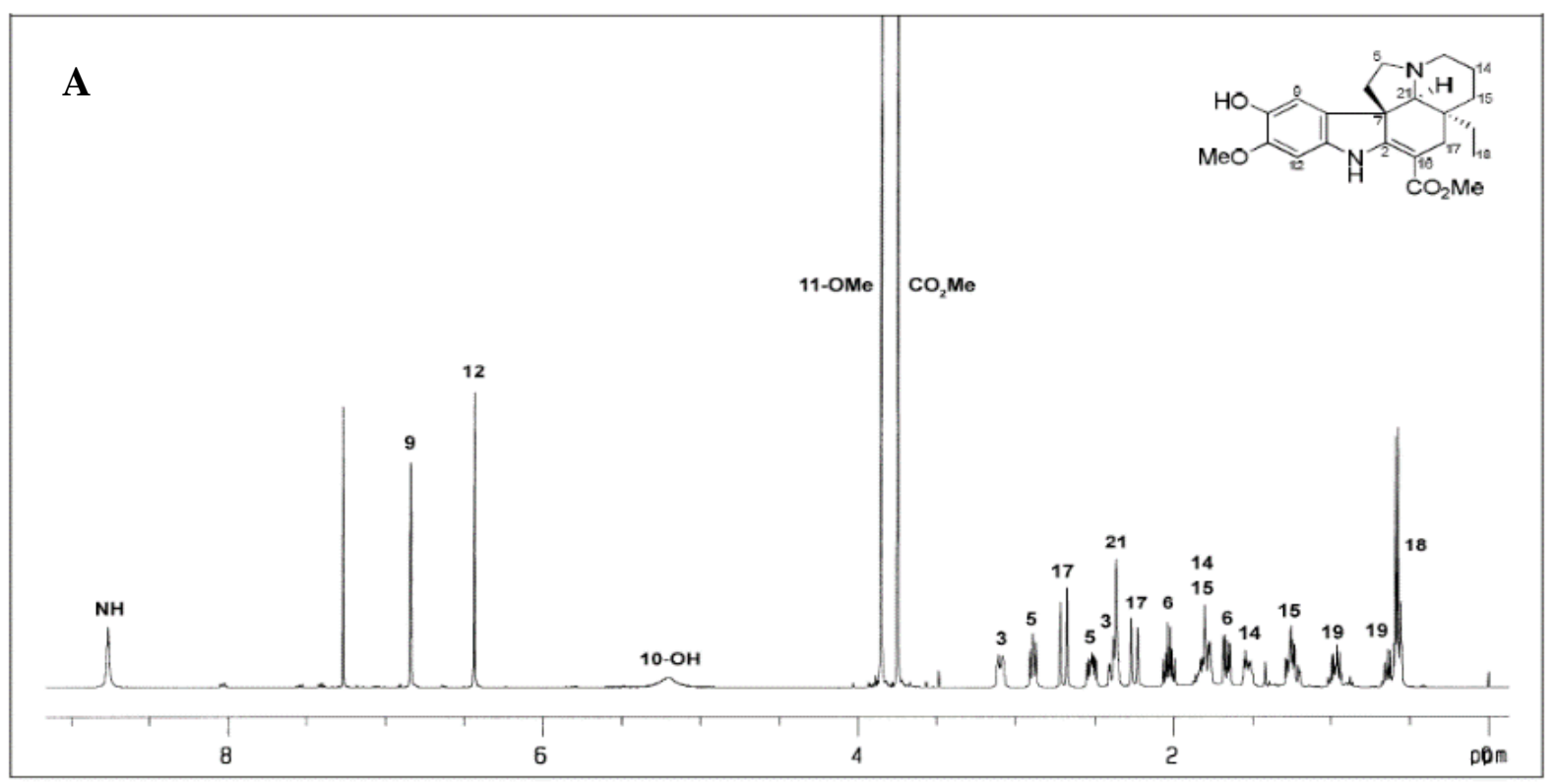

B

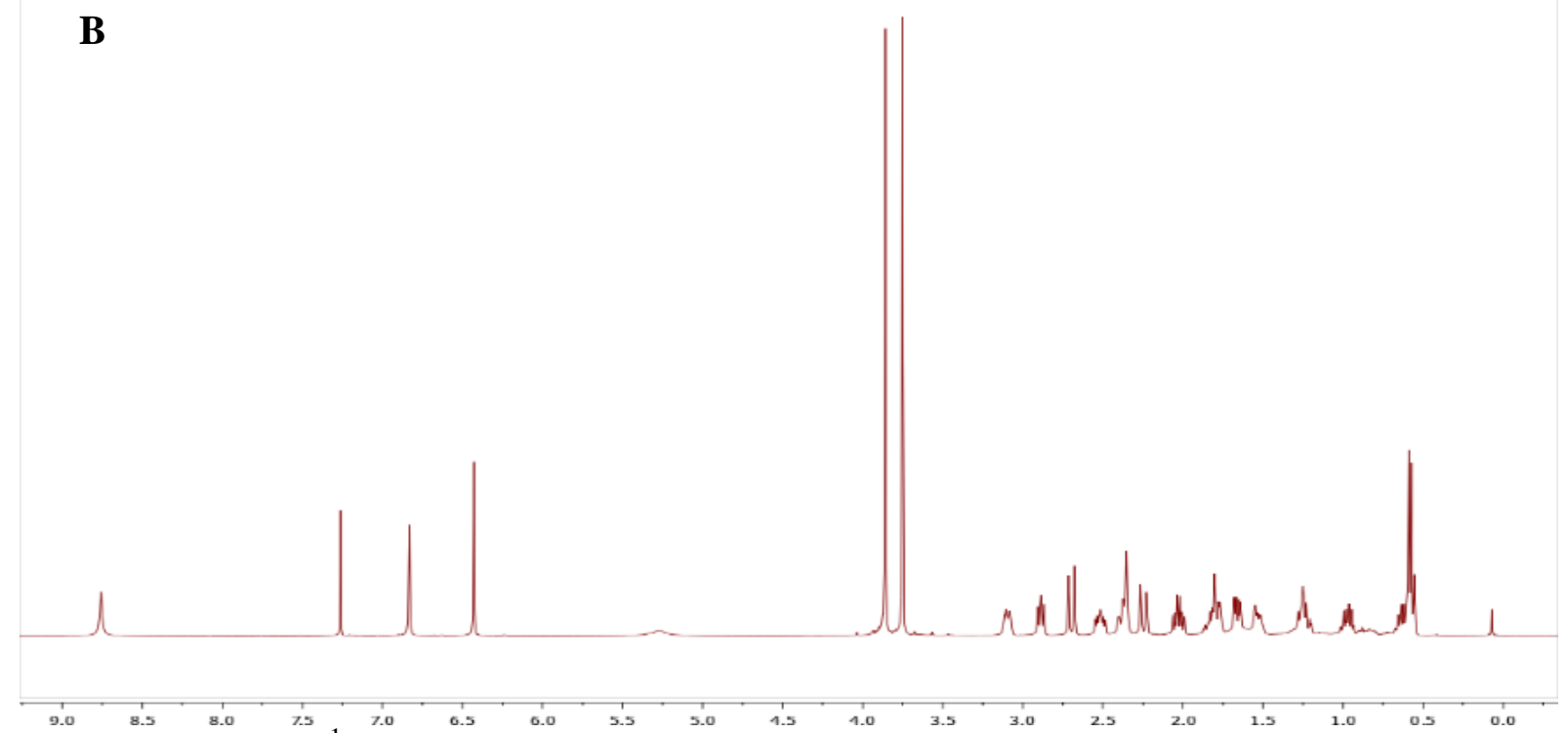

Figure S1. The ${ }^{1} \mathrm{H}^{3.0} \mathrm{NMR}$ spectrum of jerantinine $\mathrm{E}$ isolated from Tabernaemontana corymbosa $(\mathbf{A})$ and the synthesized jerantinine $\mathrm{E}^{1} \mathrm{H}$ NMR spectrum (B).

\section{Separation of the Enantiomers by Chiral HPLC}

The two enantiomers of jerantinine E were separated by chiral HPLC on a JASCO HPLC system with an AS2055 Autosampler, a PU 2089 Pump, a UV 2075 detector and a SEDEX 85 (SEDERE) detector using an analytical CHIRALPAK IB column from DAICEL Chemical Industries Ltd. A mixture of HPLC grade hexane:isopropanol 98:2 (no additives) was used as mobile phase. The flow rate was set to $2.0 \mathrm{~mL}$ per minute with an acquisition time of 20 minutes per run. Under the optimized separation conditions, $50 \mu \mathrm{L}$ of a mixture consisting of approximately $2 \mathrm{mg}$ jerantinine $\mathrm{E}$ dissolved in $1.5 \mathrm{~mL}$ hexane:isopropanol 9:1 were injected per run. Shown below in Figure $\mathbf{S} 2$ is a representative HPLC trace of a separation run (A), as well as traces of the two purified enantiomers $(\mathbf{B}$ and $\mathbf{C})$. 


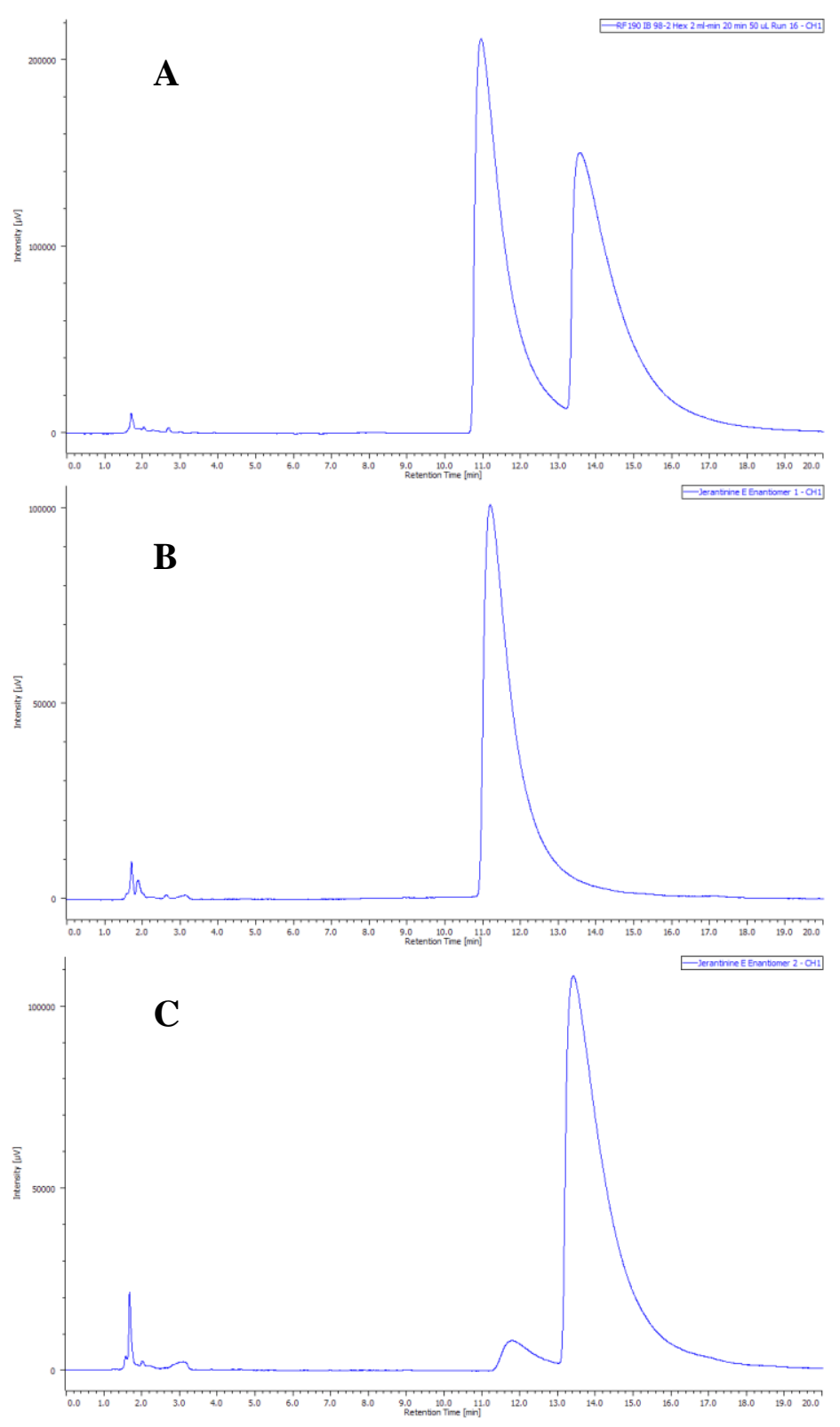

Figure S2. HPLC traces of racemic jerantinine E (A) and the two enantiomers (+)-jerantinine $\mathrm{E}(\mathbf{B})$ and (-)-jerantinine $\mathrm{E}(\mathbf{C})$.

Both enantiomers were analyzed for their optical rotatory power, which indicated that the first enantiomer (Figure S2, B) is non-natural, (+)-jerantinine E (>95\%ee; $[\alpha]_{\mathrm{D}}^{25.0}+229$ at c 0.05 in $\mathrm{CHCl}_{3}$ ) and the second enantiomer (Figure S3, C) is naturally occurring (-)-jerantinine $\mathrm{E}$ $\left(>90 \%\right.$ ee; $[\alpha]_{\mathrm{D}}^{25.0}-237$ at c 0.06 in $\left.\mathrm{CHCl}_{3}\right) .{ }^{16}$

We note that the small contamination (approximately 5\%) of (+)-jerantinine $\mathrm{E}$ in the sample of (-)-jerantinine $\mathrm{E}$ is negligible due to its minimal bio-activity.

\footnotetext{
${ }^{16}$ The manuscript describing the isolation of jerantinine $\mathrm{E}$ reports that the $[\alpha]_{\mathrm{D}}{ }^{25.0}$ is -357 at $\mathrm{c} 0.10$ in $\mathrm{CHCl}_{3}: \mathrm{K}$. H. Lim, O. Hiraku, K. Komiyama, T. S. Kam, J. Nat. Prod. 2008, 71, 1591-1594.
} 


\section{Biological Evaluation of Jerantinine E (5)}

\subsection{Evaluation of Jerantinine E (5) in Human Cancer Cell Lines ${ }^{17}$}

\section{General Information for the Evaluation of Jerantinine E (5) in Cellular Assays}

The cellular assays were performed on two human-derived breast cancer cell lines and two human-derived lung cancer cell lines. One moderately invasive cell line was selected from an invasive breast ductal carcinoma (MCF-7), whereas the second breast cancer cell line was highly invasive (MDA-MB-231). ${ }^{[18]}$ A human adenocarcinoma cell line (A549) derived from alveolar epithelial cells and an adenosquamous carcinoma cell line (HTB-178) were selected as lung cancer models. ${ }^{[19]}$

\section{Dose-Dependent Cytotoxic Effect of Jerantinine E (5)}

Cell lines A549, HTB-178, MCF-7 and MDA-MB-231 were obtained through the American Tissue Culture Collection (Manassas, VA, USA) and cell culture reagents and materials were purchased from Invitrogen. Cell lines A549, MCF-7 and MDA-MB-231 were grown in Dulbecco's Modified Eagle Medium (DMEM) containing $4.5 \mathrm{~g} / \mathrm{L}$ glucose, $10 \%$ heatinactivated fetal calf serum (FCS) and penicillin/streptomycin. HTB-178 cells were grown in complete Roswell Park Memorial Institute (RPMI) 1640 medium supplemented with 20\% FCS and penicillin/streptomycin.

Cells were grown for 24 hours in 48 well plates $(250 \mu \mathrm{L} /$ well), after which the medium was exchanged with jerantinine E (5) containing medium at the indicated concentrations (prepared from stock solutions of either $1900 \mathrm{mg} / \mu \mathrm{L}$ or $770 \mu \mathrm{g} / \mathrm{mL}$ jerantinine $\mathrm{E}(\mathbf{5})$ ), followed by an incubation for 24 or 72 hours. At the end of corresponding incubation periods, cell viability was evaluated using the MTT assay. As such, $10 \mu \mathrm{L}$ aliquots of a solution consisting of 5 $\mathrm{mg} / \mathrm{mL}$ MTT (3-(4,5-dimethyl-2-thiazoyl)-2,5-diphenyltetrazolium bromide) in PBS were added to each well, followed by incubation for a 90 minutes. The cell culture supernatants were removed and the cells were treated with $250 \mu \mathrm{L}$ of 2-propanol/0.04 N HCl $(5 \mathrm{~mL}$ of 4 $\mathrm{M} \mathrm{HCl}$ were diluted in 2-propanol until a final volume of $500 \mathrm{~mL}$ ) and incubated for 15 minutes, after which $200 \mu \mathrm{L}$ were transferred into a fresh 96 well plate. Absorbance measurements were carried out at $540 \mathrm{~nm}$ in a multi-well plate spectrophotometer (Synergy HT, Biotek) and compared with the values of control wells (i.e. no jerantinine E (5) present in the cell medium). All experiments were conducted in triplicate wells and repeated twice to report the mean \pm the standard deviation.

\footnotetext{
${ }^{17}$ Performed by Mr. Davide Staedler under the supervision of Dr. MER Sandrine Gerber-Lemaire at the Laboratory of Synthesis and Natural Products at EPFL.

${ }^{18}$ D. Staedler, E. Idrizi, B. H. Kenzaoui, L. Juillerat-Jeanneret, Cancer Chemoth. Pharm. 2011, 68, 1161-1172.

${ }^{19}$ D. Staedler, T. Magouroux, R. Hadji, C. Joulaud, J. Extermann, S. Schwungi, S. Passemard, C. Kasparian, G. Clarke, M. Gerrmann, R. Le Dantec, Y. Mugnier, D. Rytz, D. Ciepielewski, C. Galez, S. Gerber-Lemaire, L. Juillerat-Jeanneret, L. Bonacina, J. P. Wolf, Acs Nano 2012, 6, 2542-2549.
} 


\section{Racemic Jerantinine E (5) in Human-Derived Breast Cancer Cell Lines}

A

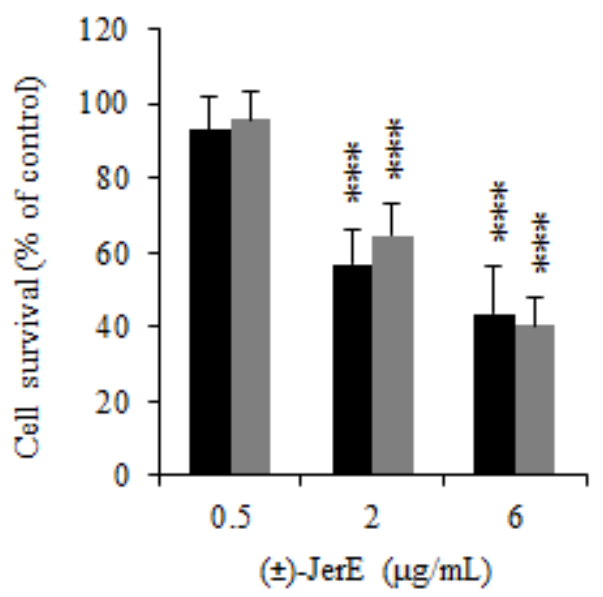

B

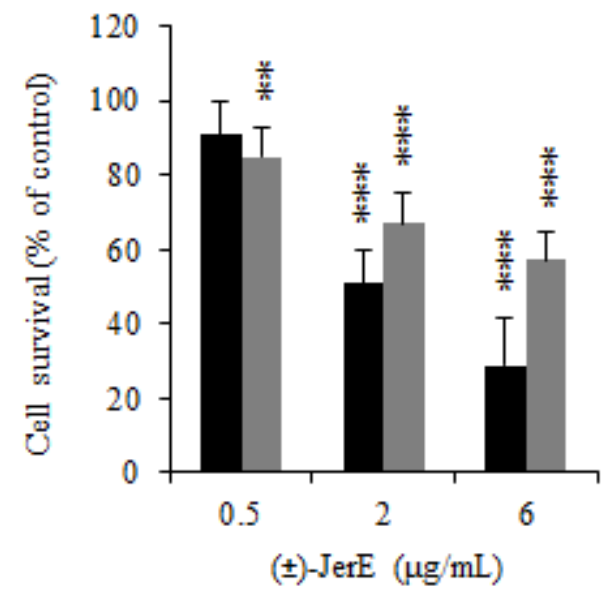

C

\begin{tabular}{|l|c|c|}
\hline Cell line & $\begin{array}{c}\mathbf{I C}_{\mathbf{5 0}} \text { after } \mathbf{2 4 h} \\
\text { exposure }(\mu \mathrm{g} / \mathrm{mL})\end{array}$ & $\begin{array}{c}\mathbf{I C}_{\mathbf{5 0}} \text { after } \mathbf{7 2 h} \\
\text { exposure }(\mu \mathrm{g} / \mathrm{mL})\end{array}$ \\
\hline MDA-MB-231 & $3.5 \pm 0.27$ & $2.1 \pm 0.15$ \\
\hline MCF-7 & $3.8 \pm 0.23$ & $6.3 \pm 0.34$ \\
\hline
\end{tabular}

Figure S3. Cytotoxic effect of ( \pm )-jerantinine E (5) on the survival of human-derived breast cancer cell lines. Human MDA-MB-231 (black bars) and MCF-7 (grey bars) breast cancer cells were exposed for 24 (A) or 72 hours (B) to increasing concentrations $(0.5,2$, and 6 $\mu \mathrm{g} / \mathrm{mL})$ of $( \pm)$-jerantinine $\mathrm{E}(\mathbf{5})$. The experiments were conducted in triplicate wells and repeated twice to report the mean \pm the standard deviation. Cells treated with $( \pm)$-jerantinine $\mathrm{E}$ (5) were compared to untreated cells using the student's $t$-test: $* * \mathrm{p}<0.01$; *** $\mathrm{p}<0.001$. The obtained $\mathrm{IC}_{50}$-values after 24 and 72 hours are tabulated in part $\mathbf{C}$. 


\section{Racemic Jerantinine E (5) in Human-Derived Lung Cancer Cell Lines}

A

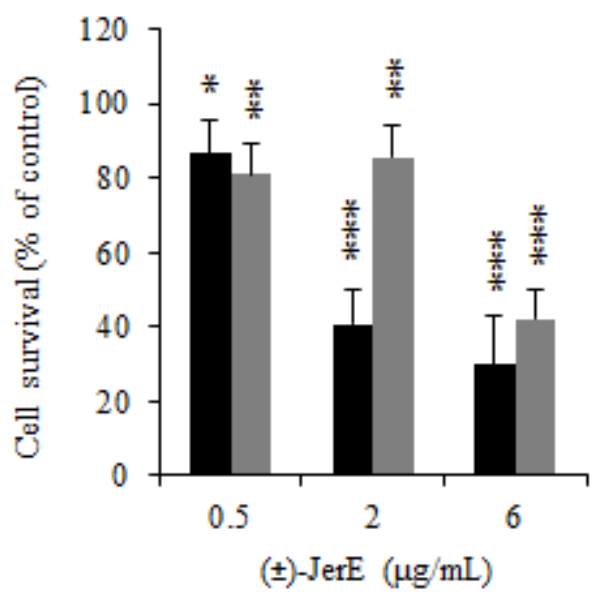

B

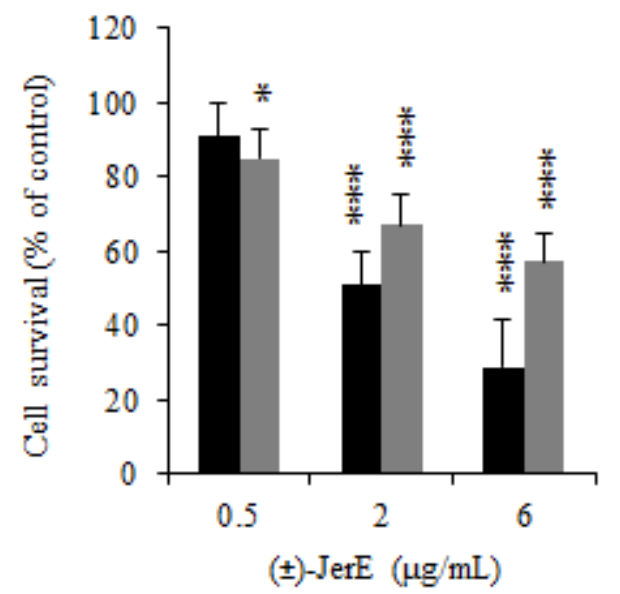

C

\begin{tabular}{|l|c|c|}
\hline Cell line & $\begin{array}{c}\mathbf{I C}_{\mathbf{5 0}} \text { after } \mathbf{2 4 h} \\
\text { exposure }(\mu \mathrm{g} / \mathrm{mL})\end{array}$ & $\begin{array}{c}\text { IC }_{\mathbf{5 0}} \text { after } \mathbf{7 2 h} \\
\text { exposure }(\mu \mathrm{g} / \mathrm{mL})\end{array}$ \\
\hline A549 & $0.7 \pm 0.05$ & $1.9 \pm 0.14$ \\
\hline HTB-178 & $5.4 \pm 0.43$ & $6.9 \pm 0.36$ \\
\hline
\end{tabular}

Figure S4. Cytotoxic effect of ( \pm -jerantinine E (5) on the survival of human-derived lung cancer cell lines. Human A549 (black bars) and HTB-178 (grey bars) lung cancer cells were exposed for 24 (A) or 72 hours (B) to increasing concentrations $(0.5,2$, and $6 \mu \mathrm{g} / \mathrm{mL})$ of $( \pm)$ jerantinine $\mathrm{E}(\mathbf{5})$. The experiments were conducted in triplicate wells and repeated twice to report the mean \pm the standard deviation. Cells treated with $( \pm)$-jerantinine $E(5)$ were compared to untreated cells using the student's $t$-test: $* \mathrm{p}<0.05 ; * * \mathrm{p}<0.01 ; * * * \mathrm{p}<0.001$. The obtained $\mathrm{IC}_{50}$ values after 24 and 72 hours are tabulated in part $\mathbf{C}$. 


\section{Non-Natural (+)-Jerantinine E (5) in Human-Derived Breast Cancer Cell Lines}

A

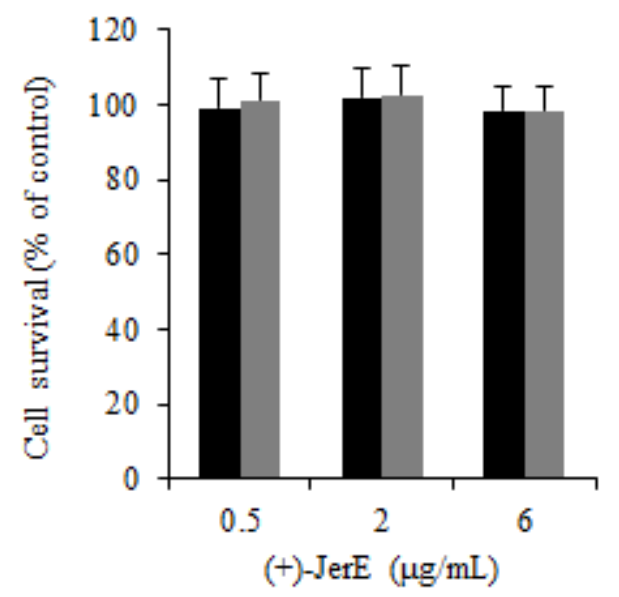

B

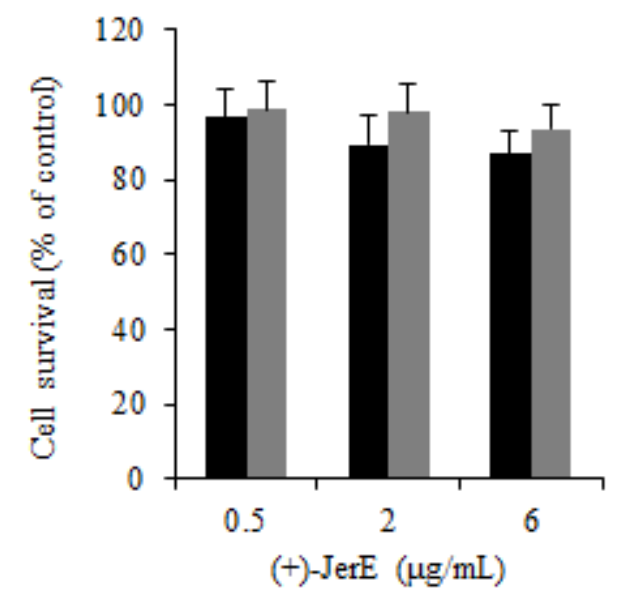

Figure S5. Cytotoxic effect of (+)-jerantinine E (5) on the survival of human-derived breast cancer cells.

Human MDA-MB-231 (black bars) and MCF-7 (grey bars) breast cancer cells were exposed for $24 \mathrm{~h}(\mathbf{A})$ or $72 \mathrm{~h}(\mathbf{B})$ to increasing concentrations $(0.5,2$ and $6 \mu \mathrm{g} / \mathrm{mL})$ of $(+)$-jerantinine $\mathrm{E}$ (5). The experiments were conducted in triplicate wells and repeated twice to report the mean \pm the standard deviation. Cells treated with (+)-jerantinine E $(\mathbf{5})$ were compared to untreated cells using the student's $t$-test and showed no significant differences.

\section{Non-Natural (+)-Jerantinine E (5) in Human-Derived Lung Cancer Cell Lines}

A

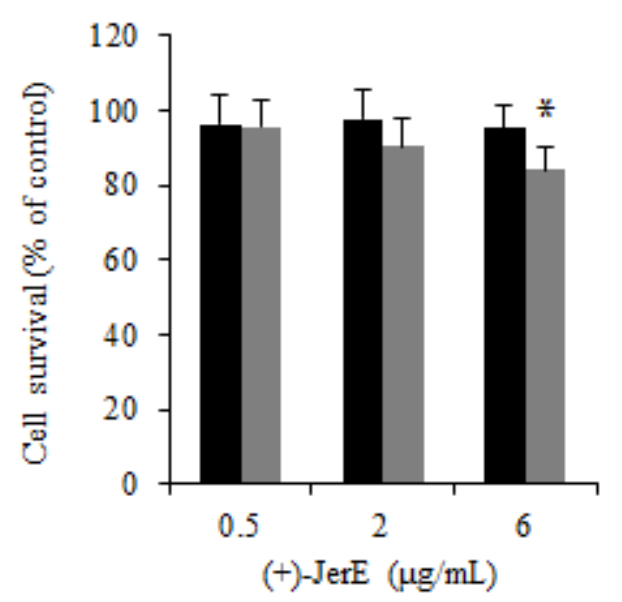

B

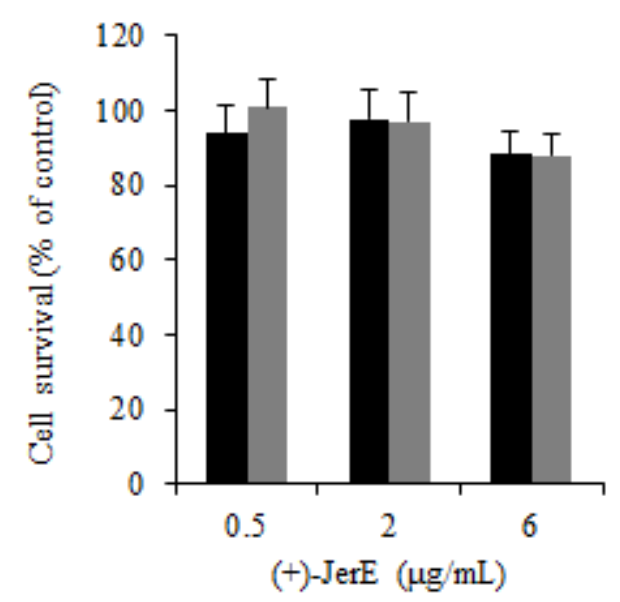

Figure S6. Cytotoxic effect of (+)-jerantinine E (5) on the survival of human-derived breast cancer cells.

Human A549 (black bars) and HTB-178 (grey bars) breast cancer cells were exposed for 24h (A) or $72 \mathrm{~h}(\mathbf{B})$ to increasing concentrations $(0.5,2$ and $6 \mu \mathrm{g} / \mathrm{mL})$ of $(+)$-jerantinine $\mathrm{E}(\mathbf{5})$. The experiments were conducted in triplicate wells and repeated twice to report the mean \pm the standard deviation. Cells treated with (+)-jerantinine E (5) were compared to untreated cells using the student's $t$-test: * $\mathrm{p}<0.05$. 


\section{Natural (-)-Jerantinine E (5) in Human-Derived Breast Cancer Cell Lines}

A

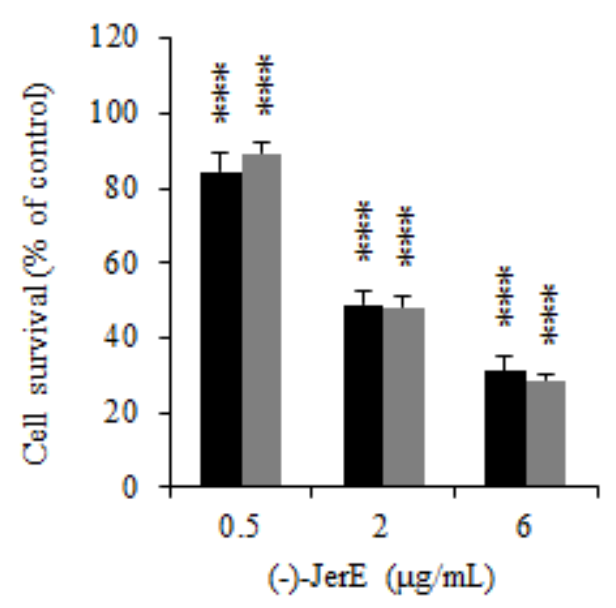

B

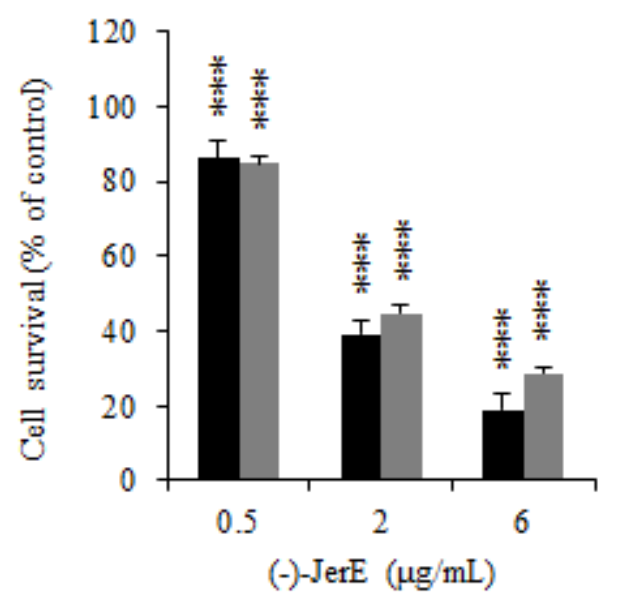

$\mathrm{C}$

\begin{tabular}{|l|c|c|}
\hline Cell line & $\begin{array}{c}\mathbf{I C}_{\mathbf{5 0}} \text { after 24h } \\
\text { exposure }(\mu \mathrm{g} / \mathrm{mL})\end{array}$ & $\begin{array}{c}\mathbf{I C}_{\mathbf{5 0}} \text { after } \mathbf{7 2 h} \\
\text { exposure }(\mu \mathrm{g} / \mathrm{mL})\end{array}$ \\
\hline MDA-MB-231 & $2.2 \pm 0.12$ & $1.7 \pm 0.09$ \\
\hline MCF-7 & $2.3 \pm 0.14$ & $2.0 \pm 0.10$ \\
\hline
\end{tabular}

Figure S7. Cytotoxic effect of (-)-jerantinine E (5) on the survival of human-derived breast cancer cell lines. Human MDA-MB-231 (black bars) and MCF-7 (grey bars) breast cancer cells were exposed for 24 (A) or 72 hours (B) to increasing concentrations $(0.5,2$, and 6 $\mu \mathrm{g} / \mathrm{mL})$ of $( \pm)$-jerantinine $\mathrm{E}(\mathbf{5})$. The experiments were conducted in triplicate wells and repeated twice to report the mean \pm the standard deviation. Cells treated with (-)-jerantinine $\mathrm{E}$ (5) were compared to untreated cells using the student's $t$-test: $* * * \mathrm{p}<0.001$. The obtained $\mathrm{IC}_{50}$-values after 24 and 72 hours are tabulated in part $\mathbf{C}$. 


\section{Natural (-)-Jerantinine E (5) in Human-Derived Lung Cancer Cell Lines}

A

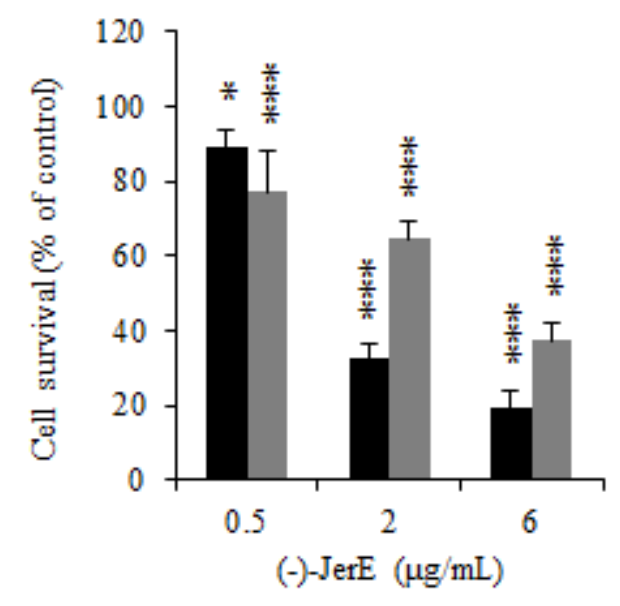

B

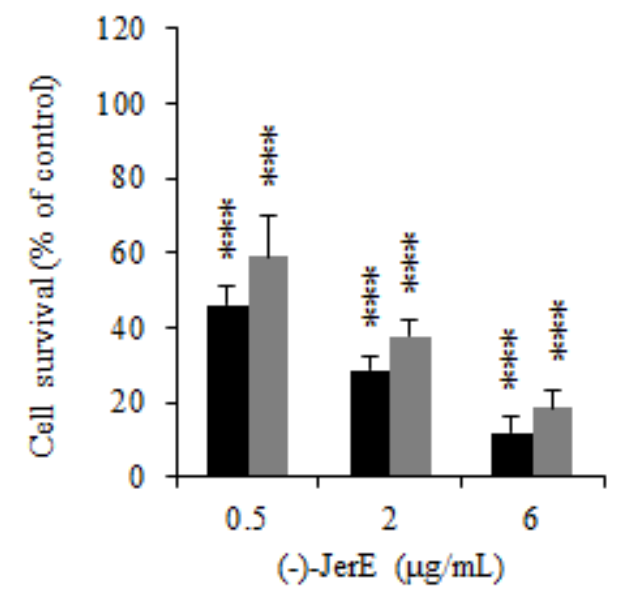

C

\begin{tabular}{|l|c|c|}
\hline Cell line & $\begin{array}{c}\mathbf{I C}_{\mathbf{5 0}} \text { after 24h } \\
\text { exposure }(\mu \mathrm{g} / \mathrm{mL})\end{array}$ & $\begin{array}{c}\mathbf{I C}_{\mathbf{5 0}} \text { after } \mathbf{7 2 h} \\
\text { exposure }(\mu \mathrm{g} / \mathrm{mL})\end{array}$ \\
\hline A549 & $1.6 \pm 0.10$ & $0.4 \pm 0.02$ \\
\hline HTB-182 & $3.4 \pm 0.24$ & $0.9 \pm 0.05$ \\
\hline
\end{tabular}

Figure S8. Cytotoxic effect of (-)-jerantinine E (5) on the survival of human-derived lung cancer cell lines. Human A549 (black bars) and HTB-178 (grey bars) lung cancer cells were exposed for $24(\mathbf{A})$ or 72 hours (B) to increasing concentrations $(0.5,2$, and $6 \mu \mathrm{g} / \mathrm{mL})$ of (-)jerantinine $\mathrm{E}(\mathbf{5})$. The experiments were conducted in triplicate wells and repeated twice to report the mean \pm the standard deviation. Cells treated with $( \pm)$-jerantinine $\mathrm{E}(\mathbf{5})$ were compared to untreated cells using the student's $t$-test: $* \mathrm{p}<0.05 ; * * * \mathrm{p}<0.001$. The obtained $\mathrm{IC}_{50}$ values after 24 and 72 hours are tabulated in part $\mathbf{C}$. 


\section{Cell Migration Assays}

The A549, HTB-178, MCF-7 and MDA-MB-231 cell lines were grown as described above. The cells were diluted in $100 \mu \mathrm{L}$ of corresponding cell culture medium (300'000 cells $/ \mathrm{mL}$ ) containing jerantinine $\mathrm{E}(\mathbf{5})$ at the desired concentration and added to the upper chamber of a two-chamber Transwell device $(6.5 \mathrm{~mm}$ diameter, $8.0 \mu \mathrm{m}$ pore size polyethylene membrane, Falcon, BD). The lower Transwell chamber contained $600 \mu \mathrm{L}$ of the corresponding cell culture medium and jerantinine E (5) at the desired concentration. After 15 hours of incubation, the cell layers were fixed in 4\% formaldehyde in PBS and cells on the upper side of the membrane were removed by swiping with a damp cotton swab. The membrane was rinsed with PBS and stained for 10 minutes with $0.05 \%$ crystal violet in $1.5 \%$ glacial acetic acid. After washing with PBS, cells of one field of the lower side of the membrane were counted under a microscope at a 200x magnification. Experiments were conducted in duplicate and repeated twice to report the mean \pm the standard deviation.

A

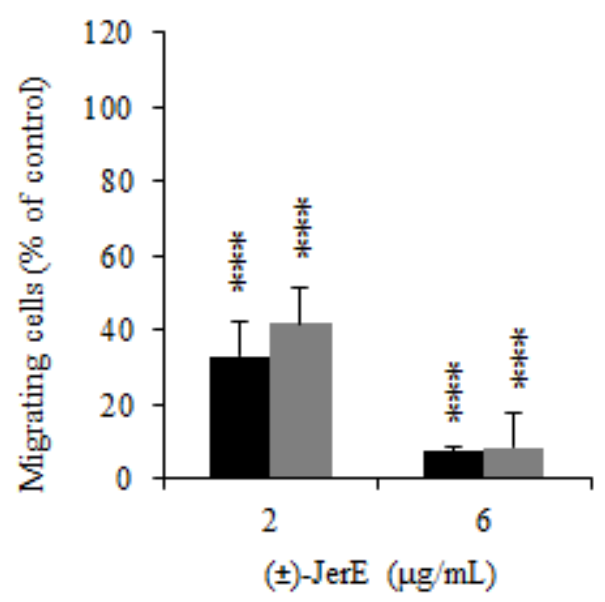

B

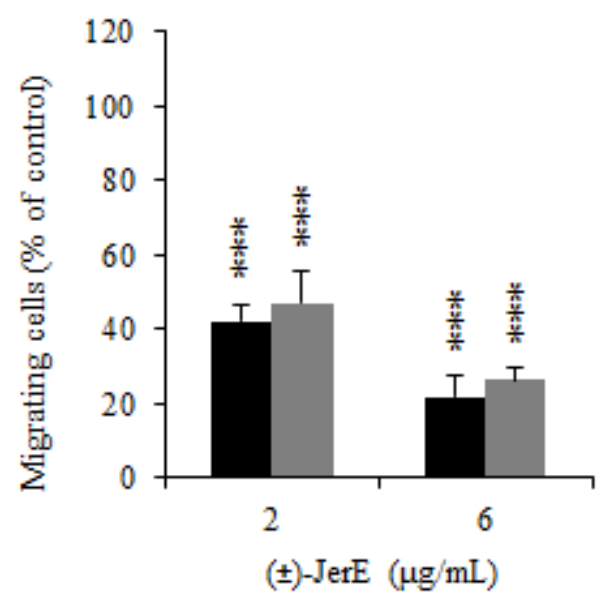

Figure S9. Migratory effect of ( \pm )-jerantinine E (5) on the migration of human-derived cancer cell lines. Human-derived MDA-MB-231 (black bars) and MCF-7 (grey bars) breast cancer cells (A) and human-derived A549 (black bars) and HTB-178 (grey bars) lung cancer cells (B) were exposed for 15 hours to 2 or $6 \mu \mathrm{g} / \mathrm{mL}$ of $( \pm)$-jerantinine $\mathrm{E}(\mathbf{5})$. The number of migrating cells through a transwell device was determined through two independent experiments to report the mean \pm the standard deviation. Migrating cells treated with $( \pm)$ jerantinine E (5) were compared to untreated cells using the student's $t$-test (we note that all comparisons were statistically significant with $* * * p<0.001)$.

Inhibition of cell migration was observed for all four cancer cell lines after $15 \mathrm{~h}$ exposure at 2 and $6 \mu \mathrm{g} / \mathrm{mL}$ concentrations of $( \pm$ )-jerantinine E (5) (Figure S9). The inhibition was dosedependent and particularly marked in breast cancer cells (Figure S9, A). The cell survival after 15 hours of $( \pm$ )-jerantinine $\mathrm{E}(\mathbf{5})$ exposure to the corresponding cell lines was determined to investigate if the antimigratory effect is simply due to cytotoxicity. The results of this control experiment are summarized below in Figure $\mathbf{S 1 0}$ and indicated that the antimigratory effect is not solely due to cytotoxicity as the observed inhibition of cell migration was much more significant than the observed cytotoxic effect after 15 hours. 


\section{A}

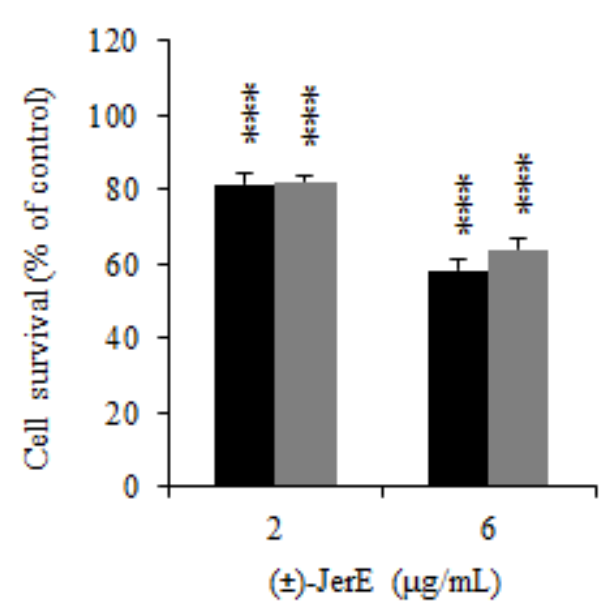

B

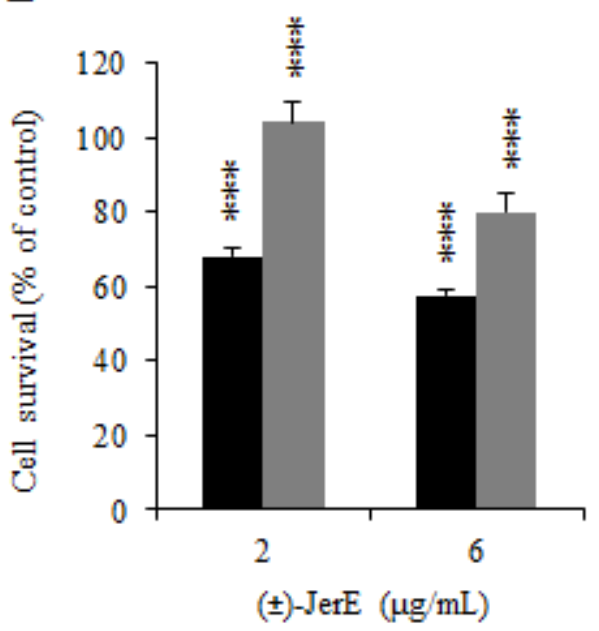

Figure S10. Cytotoxic effect of ( \pm )-jerantinine E (5) on the survival of human-derived breast and lung cancer cell lines. Human-derived MDA-MB-231 (black bars) and MCF-7 (grey bars) breast cancer cells (A) and human-derived A549 (black bars) and HTB-178 (grey bars) lung cancer cells (B) were exposed for 15 hours to 2 or $6 \mu \mathrm{g} / \mathrm{mL}$ of ( \pm )-jerantinine E (5). The experiments were conducted in triplicate wells and repeated twice to report the mean \pm the standard deviation. Cells treated with ( \pm )-jerantinine E (5) were compared to untreated cells using the student's $t$-test: $* * * \mathrm{p}<0.001$.

\subsection{Impedance and Cell Staining Assays ${ }^{20}$}

Cytotoxicity assay: A MTT [3-(4,5-dimethylthiazol-2-yl)-2,5-diphenyltetrazolium bromide] assay was used to determine the $\mathrm{IC}_{50}$ of ( \pm )-jerantinine E (5) with L-929 (DSMZ ACC 2) mouse fibroblast and PtK2 (ATCC CCL-56) potoroo cell lines (Figure S11). As such, $60 \mu \mathrm{L}$ of serial dilutions of $( \pm)$-jerantinine $\mathrm{E}(5)$ (stock concentration $1 \mathrm{mg} / \mathrm{mL}$ in $\mathrm{MeOH}$ ) were added to $120 \mu \mathrm{L}$ aliquots of a cell suspension $\left(50000 \mathrm{~mL}^{-1}\right)$ in 96 -well microplates. Blank and solvent controls were incubated under identical conditions. After 5 days, $20 \mu \mathrm{L}$ MTT in phosphate buffered saline (PBS) were added to a final concentration of $0.5 \mathrm{mg} \mathrm{mL}^{-1}$. After 2 $\mathrm{h}$, the resulting precipitate of formazan crystals was centrifuged, and the supernatant discarded. The precipitate was washed with $100 \mu \mathrm{L}$ PBS and dissolved in $100 \mu \mathrm{L}$ isopropanol containing $0.4 \%$ hydrochloric acid. The microplates were gently shaken for 20 min to ensure a complete dissolution of the formazan and finally measured at $595 \mathrm{~nm}$ using an ELISA plate reader. All experiments were carried out in two parallels. Activity values were calculated as the mean with respect to the controls set to 100\%. Cell lines were grown in media recommended by the supplier (DSMZ or ATCC).

\footnotetext{
${ }^{20}$ Performed by Ms. Aruna Raja, Dr. Raimo Franke and Dr. Florenz Sasse at the Helmholtz Centre for Infection Research in Braunschweig.
} 


\section{Cytotoxicity}

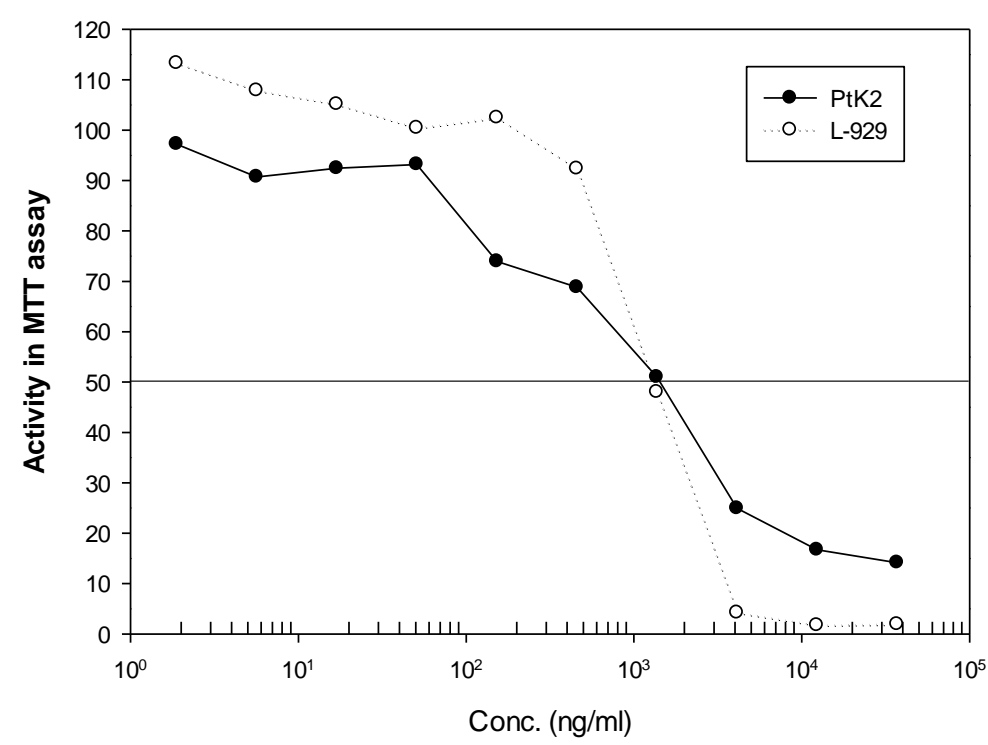

Figure S11: Cytotoxicity of ( \pm )-jerantinine E (5) with mouse fibroblast cells (L-929) and rat kangaroo kidney cells (PtK2) indicating an $\mathrm{IC}_{50}$ of $14 \mu \mathrm{g} / \mathrm{ml}$.

\section{Impedance profiling}

The impedance measurements were performed with small modifications on a RT-CES system (xCelligence) from Acea Biosciences (Roche), which has been described previously. ${ }^{21}$ For time-dependent cell response profiling, $60 \mu \mathrm{L}$ of Dulbecco modified Eagle medium (DMEM) were added to 96-well E-Plate to obtain background readings followed by the addition of 120 $\mu \mathrm{L}$ cell suspension of L-929 cells. After each step, the E-Plates were incubated for 30 minutes at room temperature and then placed on the reader in the incubator for continuous recording of impedance as reflected by the cell index. After 24 hours of incubation the cells were treated with the compounds. To prepare ( \pm )-jerantinine E (5) for screening, the stock solution (10 $\mathrm{mM}$ in DMSO) was diluted with DMEM to get a final test concentration of the $\mathrm{IC}_{90}$ and less than $0.1 \%$ DMSO. $1 \mu \mathrm{L}$ of each prepared solution was then transferred into the 96-well EPlate. Each E-plate also contained wells with DMSO only as a solvent control. All measurements were performed in triplicates and run for 5 days. The time-dependent cellular response profiles (TCRP) were recorded by the Roche RTCA Software, Version 1.2. Data processing and mining workflow was implemented in the statistical programming language $\mathrm{R}$, Version 2.12.2 (R Development Core Team, 2011). The following additional R packages were used in addition: class $^{22}$, gplots ${ }^{23}$ and MASS. ${ }^{21}$ For the development of the $\mathrm{R}$ code the integrated development environment R Studio, Version 0.94.92, was used. The workflow

\footnotetext{
${ }^{21}$ a) K. Solly, X. Wang, X. Xu, B. Strulovici, W. Zheng, Assay Drug Dev. Technol. 2004, 2, 363; b) J. M. Atienza, N. Yu, S. L. Kirstein, B. Xi, X. Wang, X. Xu, Y. A. Abassi, Assay Drug Dev. Technol. 2006, 4, 597; c) Y. A. Abassi, B. Xi, W. Zhang, P. Ye, S. L. Kirstein, M. R. Gaylord, S. C. Feinstein, X. Wang, X. Xu, Chem. Biol. 2009, 16, 712 .

${ }^{22}$ W. N. Venables, B. D. Ripley, Modern Applied Statistics with S (4th ed.) 2002, Springer New York.

${ }^{23}$ G. R. Warnes gplots: Various R programming tools for plotting data. 2010. Retrieved from http://cran.rproject.org/package=gplots.
} 
starts by importing the raw impedance data which is provided by the RTCA software as cell index (CI) data. The CI is already background corrected and is calculated as follows (Eq. 1): ${ }^{24}$ Eq. 1: $\quad \mathrm{CI}(\mathrm{t})=\frac{\mathrm{R}_{\mathrm{t}}-\mathrm{R}_{\mathrm{b}}}{\mathrm{Z}_{\mathrm{n}}}$

where $C I(t)$ is the cell index at time point $t, R_{t}$ is defined as measured electrode impedance of the well with the cells in the medium at a certain time point and $\mathrm{R}_{\mathrm{b}}$ as measured background impedance of the well with the cell medium alone. $Z_{n}$ is a frequency factor which corrects for different frequencies of the alternating voltage the xCelligence system can use, with the standard setting being $Z_{n}=15$. The raw data were imported into $R$ and normalized as suggested by Abassi and colleagues by dividing the cell indices for each time point after compound addition by the cell index at a reference time point (Eq. 2) ${ }^{23}$ As reference time point, the last measurement before compound addition was taken. For subsequent analysis, only the measurements starting at the reference time point (with normalized cell index $=1$ ) and later were considered.

$$
\text { Eq. 2: } \quad N C I=\frac{C I_{t}}{C I_{t}(\text { reference })}
$$

The reference compounds and ( \pm )-jerantinine E (5) with unknown mode of action were measured as triplicates which were randomly distributed over the microtiter plates (using sampling without replacement in R) to avoid batch effects.

Detection and removal of outliers was carried out using the median polishing procedure. The central idea of the data mining concept is to use cubic smoothing splines for the approximation of the impedance data and as dimension reduction technique. This approach has the benefit of avoiding the curse of dimensionality and the Runge phenomenon that occurs for high polynomials, while keeping the complexity of the data set. The smooth.spline function of $\mathrm{R}$ was used for TCRP approximation. As set of descriptors the spline basis coefficients were extracted to construct a distance matrix that was used for hierarchical cluster analysis. A heatmap was constructed that displays the Z-transformed values of the 22 descriptors (= basis spline coefficients). Hierarchical cluster analysis of the reference compounds together with the compound of unknown mode of action was carried out. Coclustering of the compound of unknown mode of action with reference compounds with known activity class label is used to predict the mode of action. The results of the impedance profiling are shown below in Figure S12.

\footnotetext{
${ }^{24}$ N. Ke, B. Xi, P. Ye, W. Xu, M. Zheng, L. Mao, M. J. Wu, J. Zhu, J. Wu, W. Zhang, J. Zhang, J. Irelan, X. Wang, X. Xu, Y. A. Abassi, Anal. Chem. 2010, 82, 6495.
} 

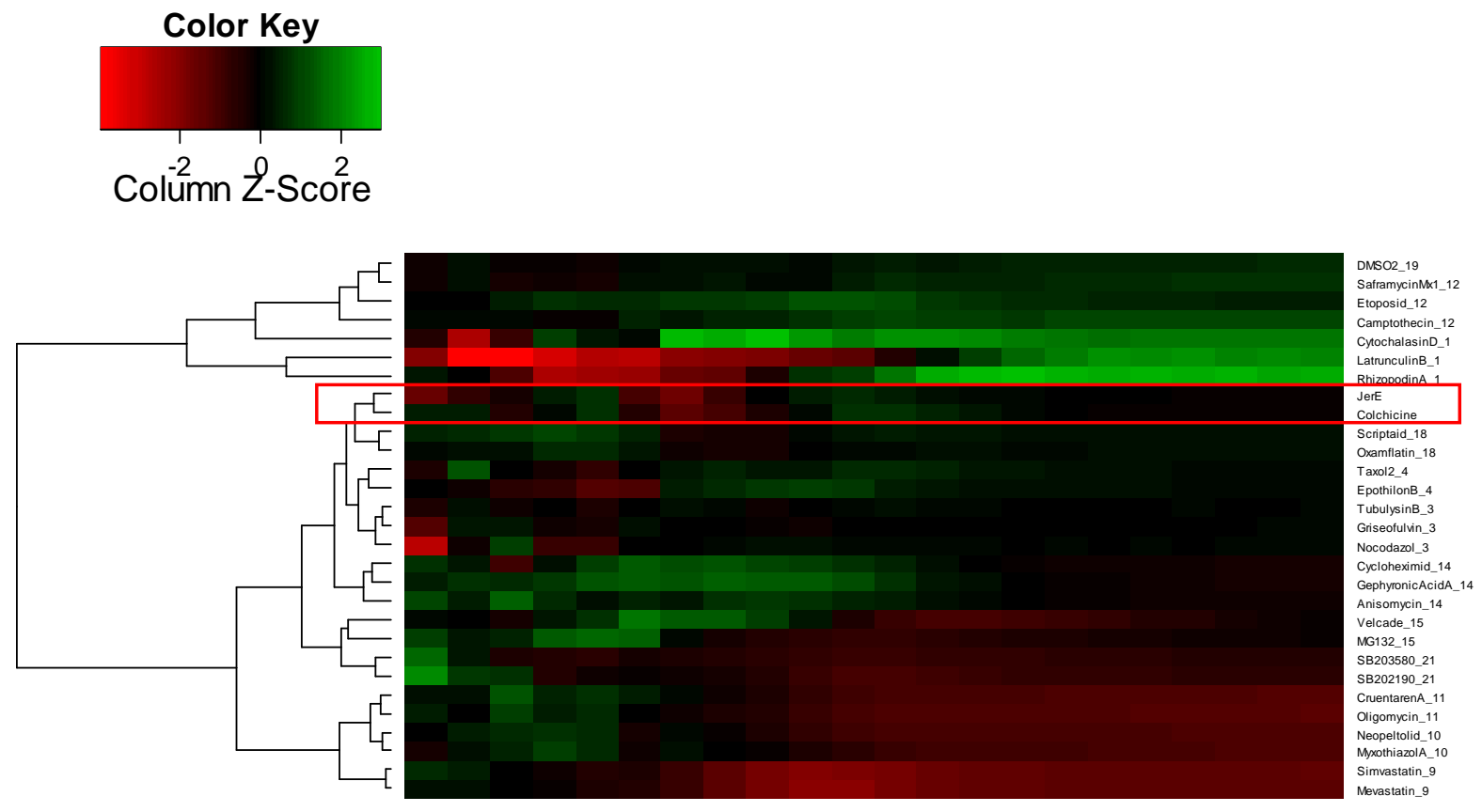

Figure S12. Cluster analysis based on impedance monitoring curves shows that the closest neighbour of $( \pm)$-jerantinine $\mathrm{E}(\mathbf{5}, \mathrm{JerE})$ is colchicin, a known tubulin disrupting agents.

Cell Staining: PtK2 cells (ATCC CCL-56) were grown in $750 \mu \mathrm{L}$ medium in 4-well plates (Nunc) on glass coverslips, and incubated with $( \pm)$-jerantinine $\mathrm{E}(\mathbf{5}, 2 \mu \mathrm{g} \mathrm{mL}-1)$ overnight. For $\alpha$-tubulin staining, cells were fixed with cold $\left(-20^{\circ} \mathrm{C}\right) \mathrm{MeOH} /$ acetone $(1: 1)$ for $10 \mathrm{~min}$ and incubated with a mouse anti $\alpha$-tubulin antibody (1:100; Sigma) followed by a secondary Alexa Fluor 488 labelled goat anti-mouse $\operatorname{IgG}$ antibody (1:200; Molecular Probes) and mounted in ProLong Antifade Gold (Molecular Probes), which included DAPI (4',6diamidino-2-phenylindole) to stain the nuclei. The results of the immunofluorescent staining are depicted below in Figure S13. 

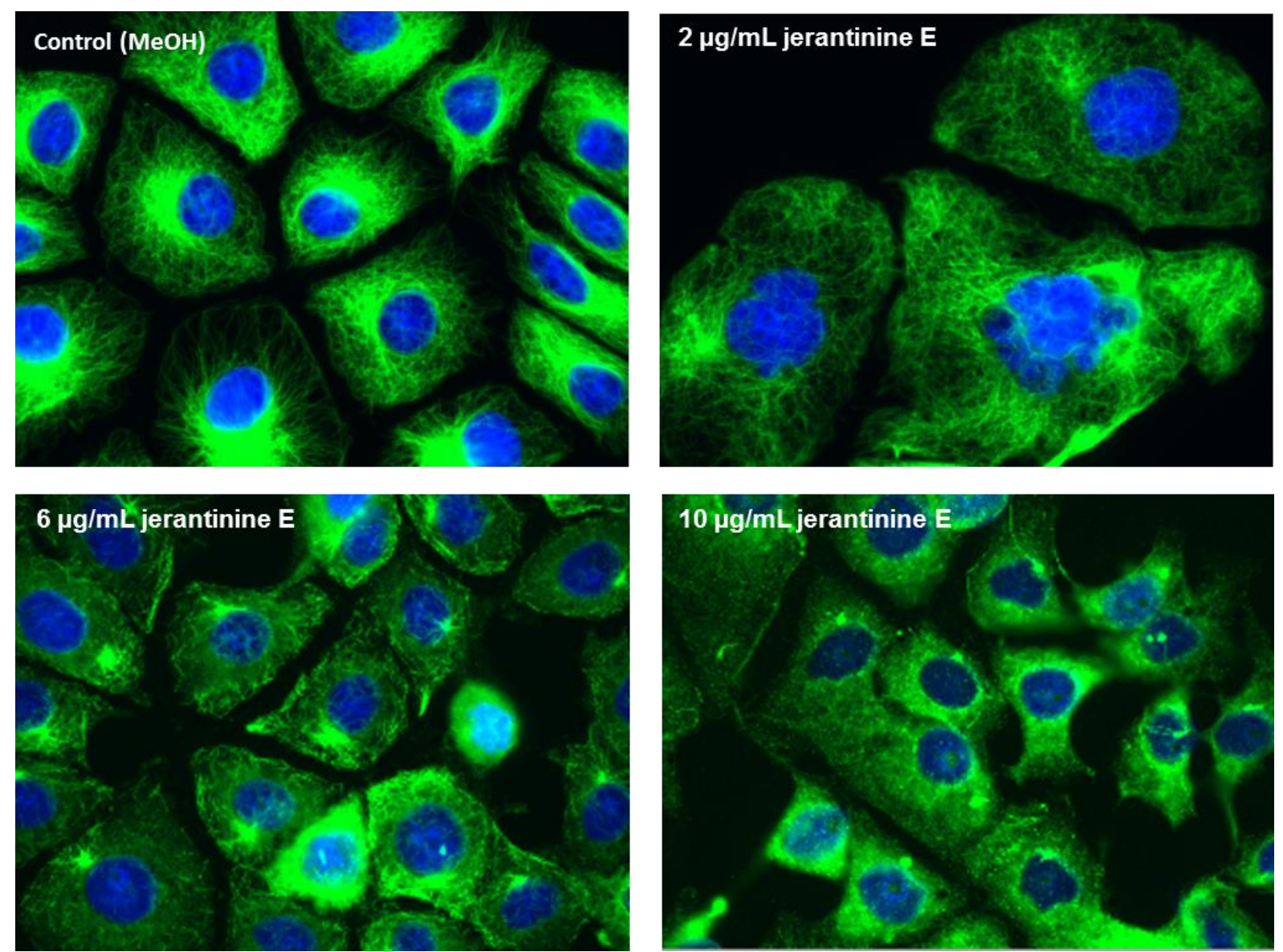

Figure S13. Immunofluorescent staining of untreated PtK2 kidney cells (control/MeOH) and cells exposed to $2 \mu \mathrm{g} / \mathrm{mL}, 6 \mu \mathrm{g} / \mathrm{mL}$ and $10 \mu \mathrm{g} / \mathrm{mL}( \pm$ )-jerantinine E (5) showing the effect on microtubules (green) and the cell nucleus (blue).

\subsection{Tubulin Polymerization Assay ${ }^{17}$}

Effects on tubulin polymerization were assessed at $0.5,1,3,5$ and $10 \mu \mathrm{M}$ for both enantiomers and racemic jerantinine E (5) using the Tubulin Polymerization Assay Kit purchased from Cytoskeleton (cat. no. BK011P). The assay was carried out according to the corresponding protocol instructions. The compounds paclitaxel and colchicine (at $3 \mu \mathrm{M}$; two different stocks of colchicine, purchased from Sigma-Aldrich, were freshly prepared and tested in two independent duplicates) were used as tubulin polymerization enhancer and inhibitor controls, respectively. The assay was performed applying the conditions for tubulin polymerization inhibition detection. Stock solutions of test compounds were prepared at 2 $\mathrm{mM}$ in DMSO. Measurements were obtained in duplicate form and repeated twice. The $\mathrm{IC}_{50}-$ values were calculated form the dose-response curve during the growth phase. Summarized below are the $\mathrm{IC}_{50}$-values of both enantiomers and racemic jerantinine $\mathrm{E}(\mathbf{5})$ as well as the inhibition of tubulin polymerization values at $3 \mu \mathrm{M}$ (including colchicine). 
$\mathrm{IC}_{50}-$ values of $( \pm)$-jerantinine $\mathrm{E},(-)$-jerantinine $\mathrm{E}$ and (+)-jerantinine $\mathrm{E}$ :

\begin{tabular}{|c|c|c|}
\hline Compound & IC50 $_{\mathbf{5 0}}(\boldsymbol{\mu} \mathbf{g} / \mathbf{m L})$ & IC $_{\mathbf{5 0}}(\boldsymbol{\mu M})$ \\
\hline ( \pm -Jerantinine E & $3.89 \pm 0.11$ & $10.1 \pm 0.28$ \\
\hline (+)-Jerantinine E & $>>4$ & $>>10$ \\
\hline (-)-Jerantinine E & $0.171 \pm 0.01$ & $0.446 \pm 0.02$ \\
\hline
\end{tabular}

Inhibition of tubulin polymerization at $3 \mu \mathrm{M}$ : comparison between jerantinine $\mathrm{E}$, (-)jerantinine $\mathrm{E},(+)$-jerantinine $\mathrm{E}$ and colchicine.

\begin{tabular}{|c|c|}
\hline Compound & \% of inhibition \\
\hline ( \pm -Jerantinine E & $18.4 \% \pm 0.7 \%$ \\
\hline (+)-Jerantinine E & $11.8 \% \pm 0.5 \%$ \\
\hline (-)-Jerantinine E & $79.1 \% \pm 2.3 \%$ \\
\hline Colchicine & $75.0 \% \pm 2.5 \%$ \\
\hline
\end{tabular}

We note that (-)-jerantinine E (5) was a more effective inhibitor of tubulin polymerization than colchicine (the difference was statistically significant with ${ }^{*} \mathrm{p}<0.05$ (Student $t$ test)).

\section{Spectra of New Compounds}

Shown below are the corresponding ${ }^{1} \mathrm{H},{ }^{13} \mathrm{C}$ NMR and IR spectra of the above fully characterized new compounds. All ${ }^{1} \mathrm{H}$ NMR spectra were obtained at $400 \mathrm{MHz}$ and all ${ }^{13} \mathrm{C}$ NMR spectra were obtained $101 \mathrm{MHz}$. Deuterated chloroform or dichloromethane, as indicated above in the tabulated NMR data for each fully characterized compound, were used as solvent to carry out the corresponding NMR characterization. 

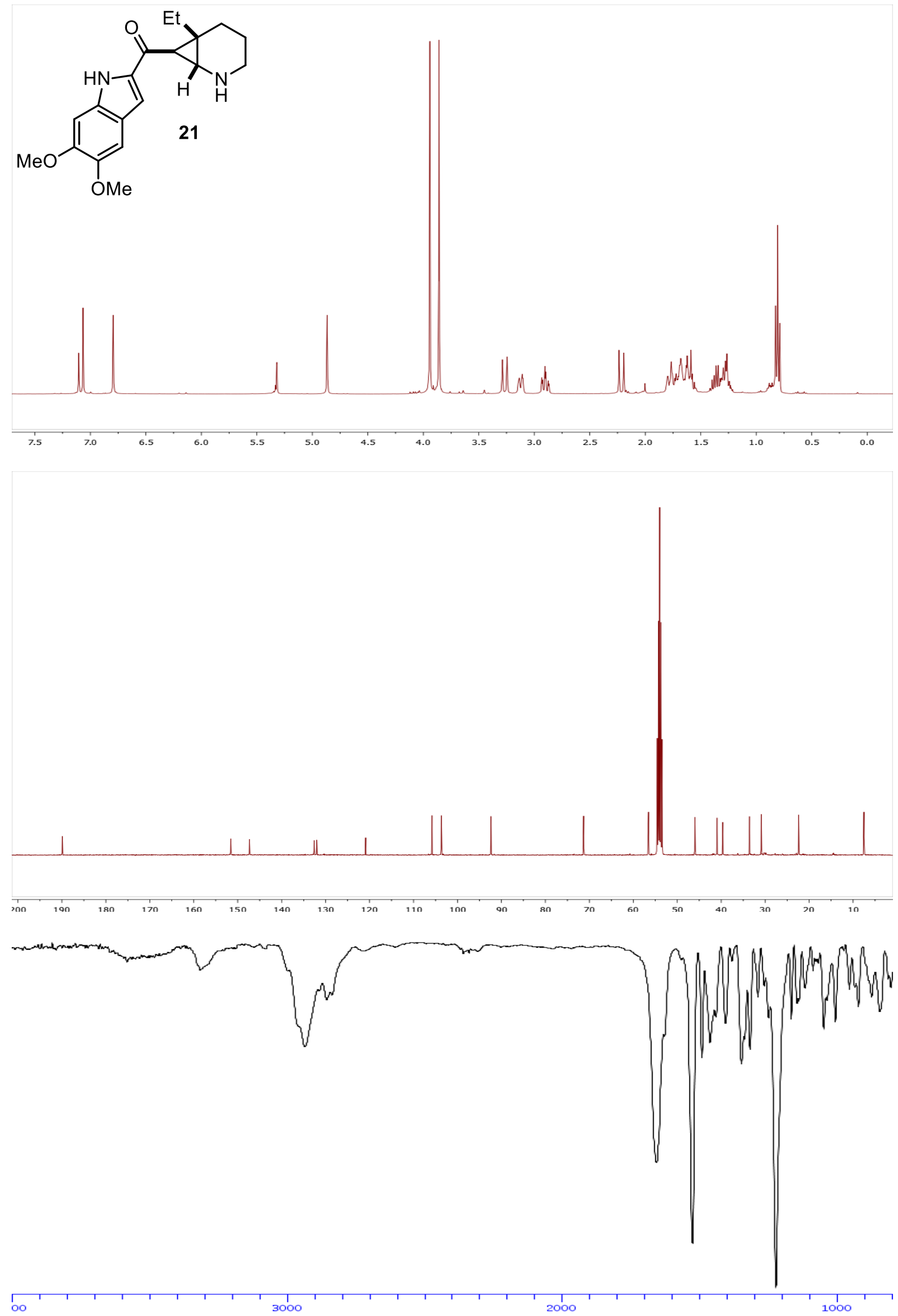


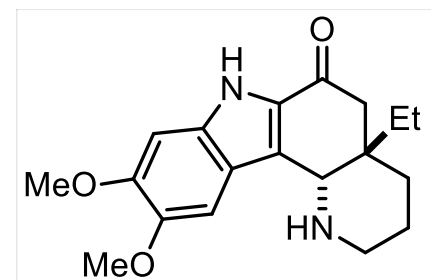

22

Muth Mhure
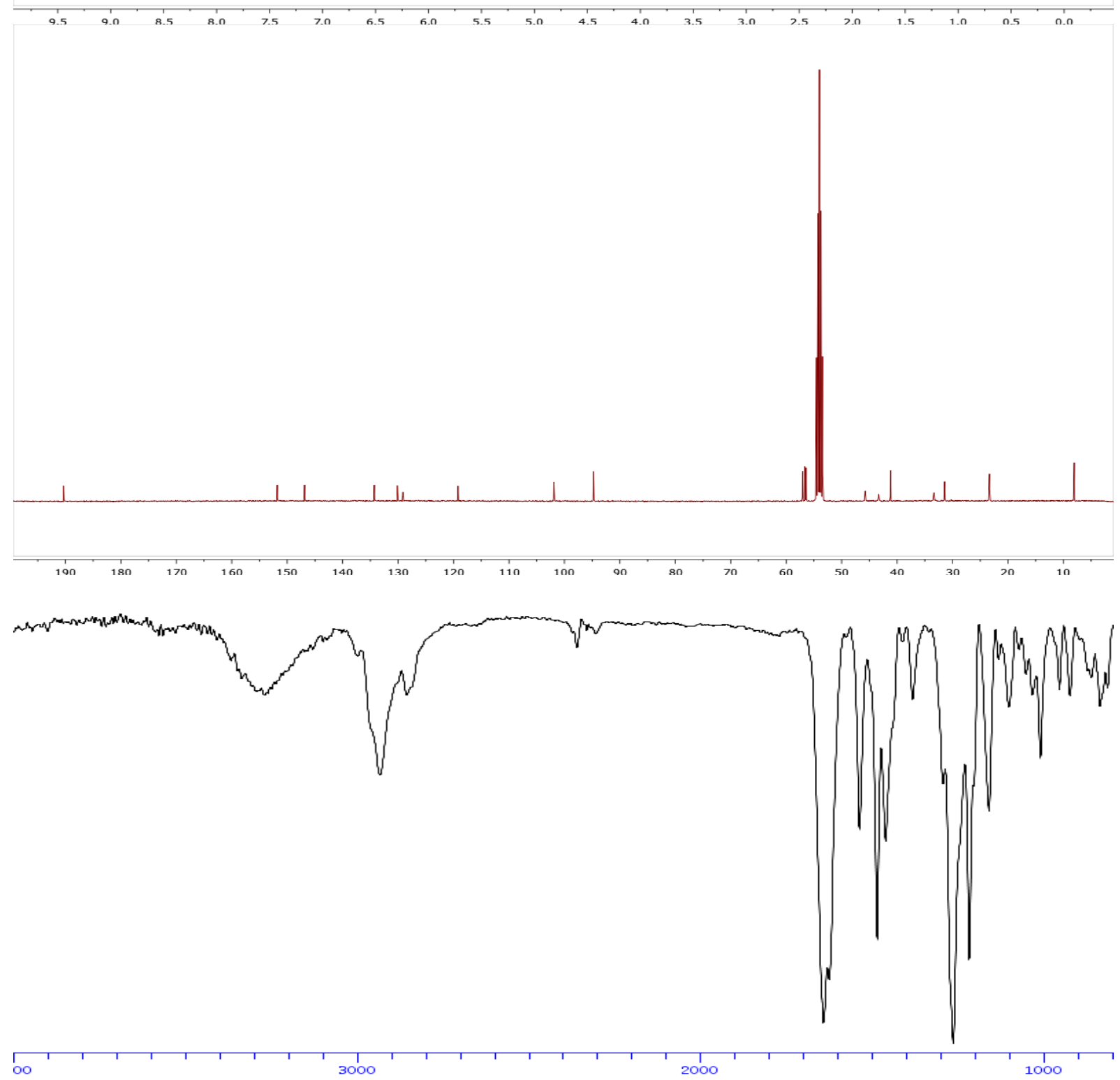


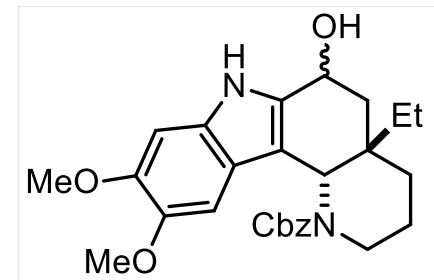

$12 a$
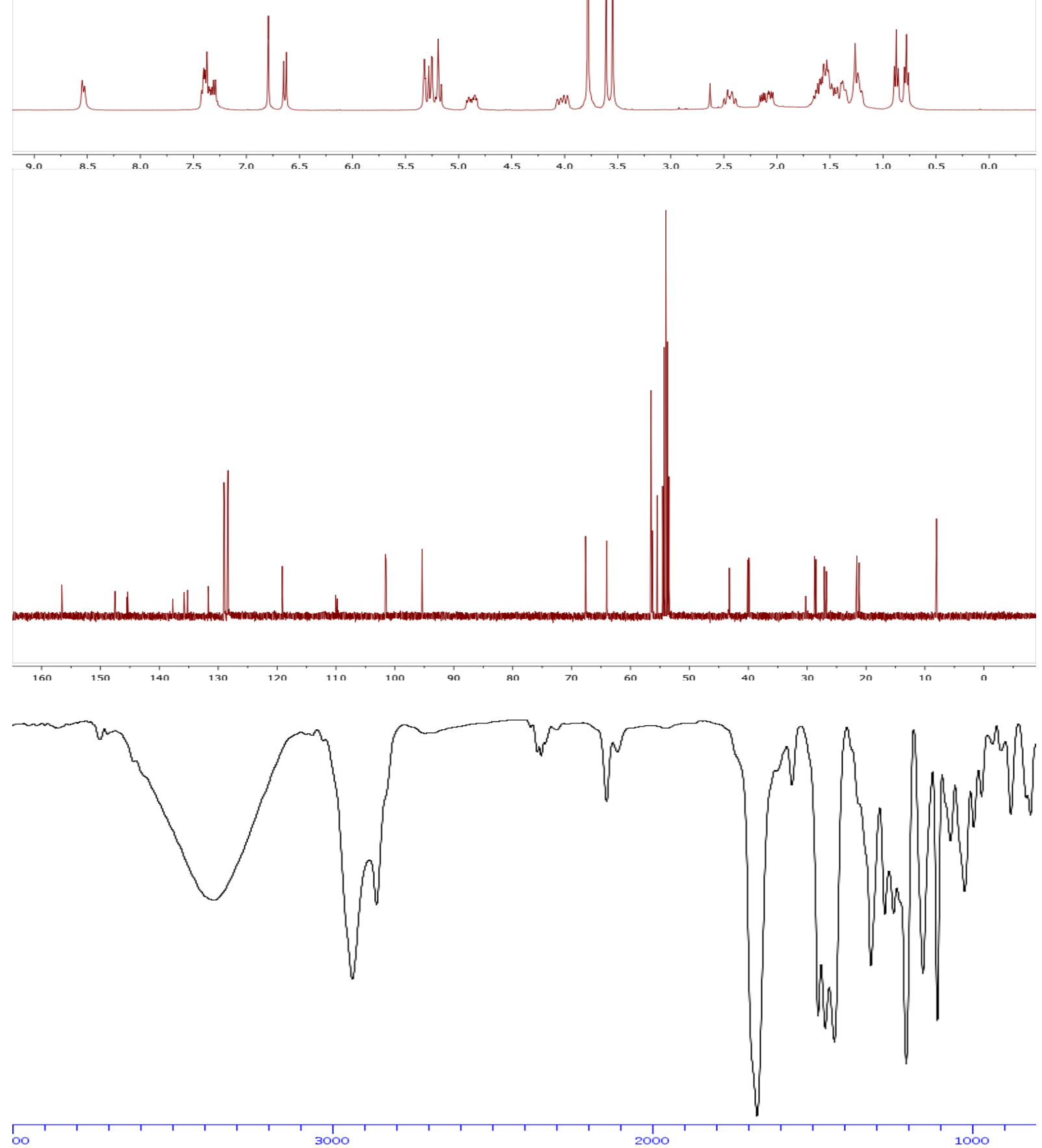


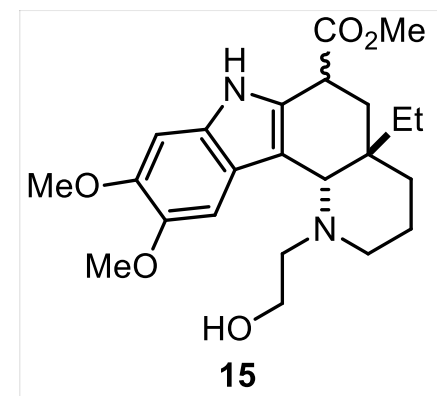

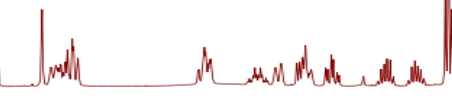
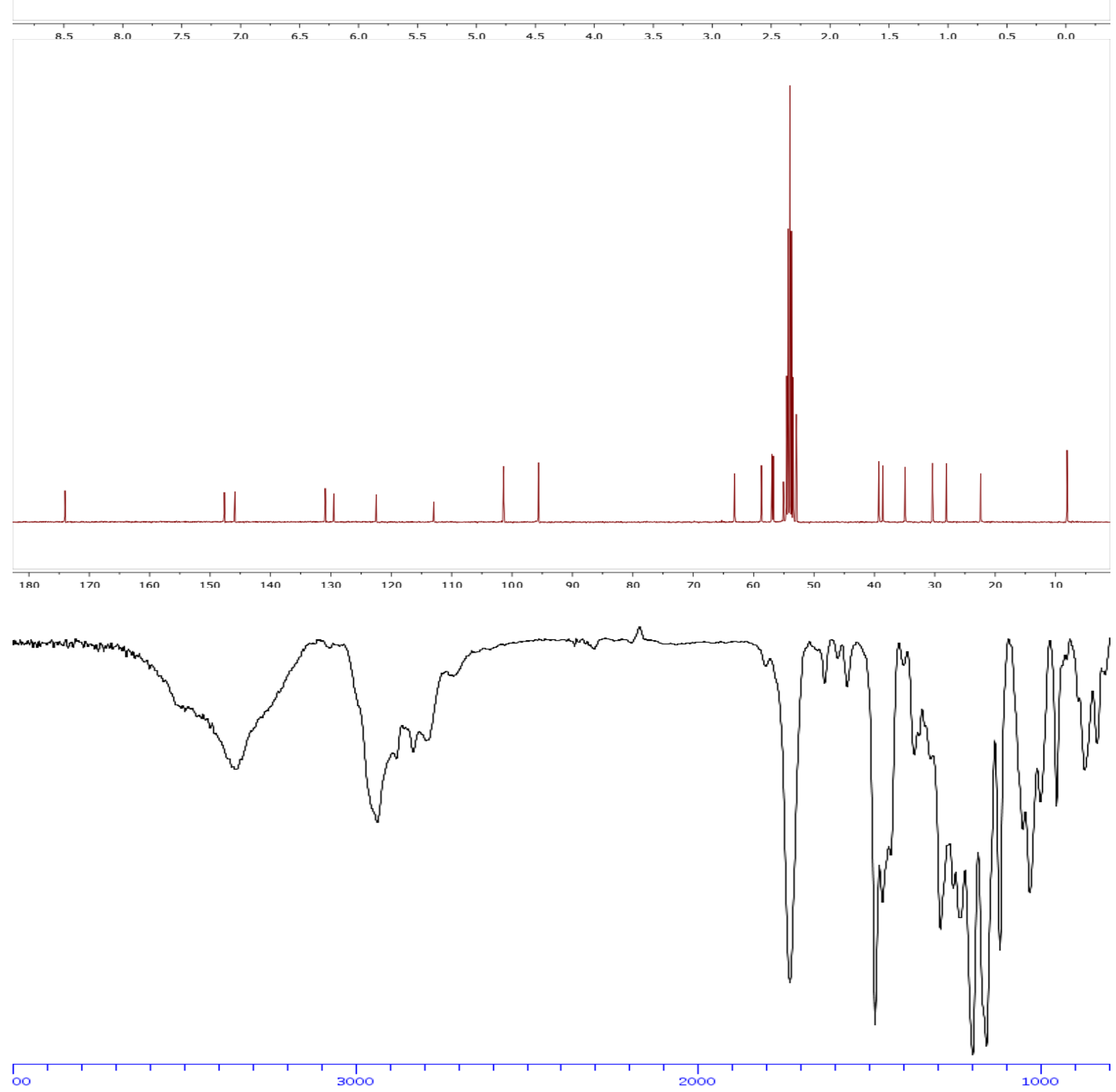


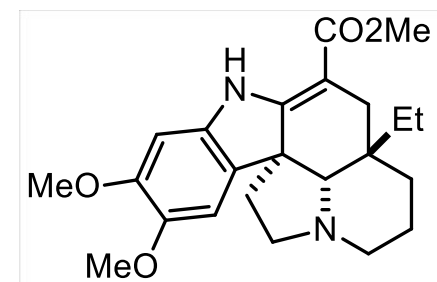

16
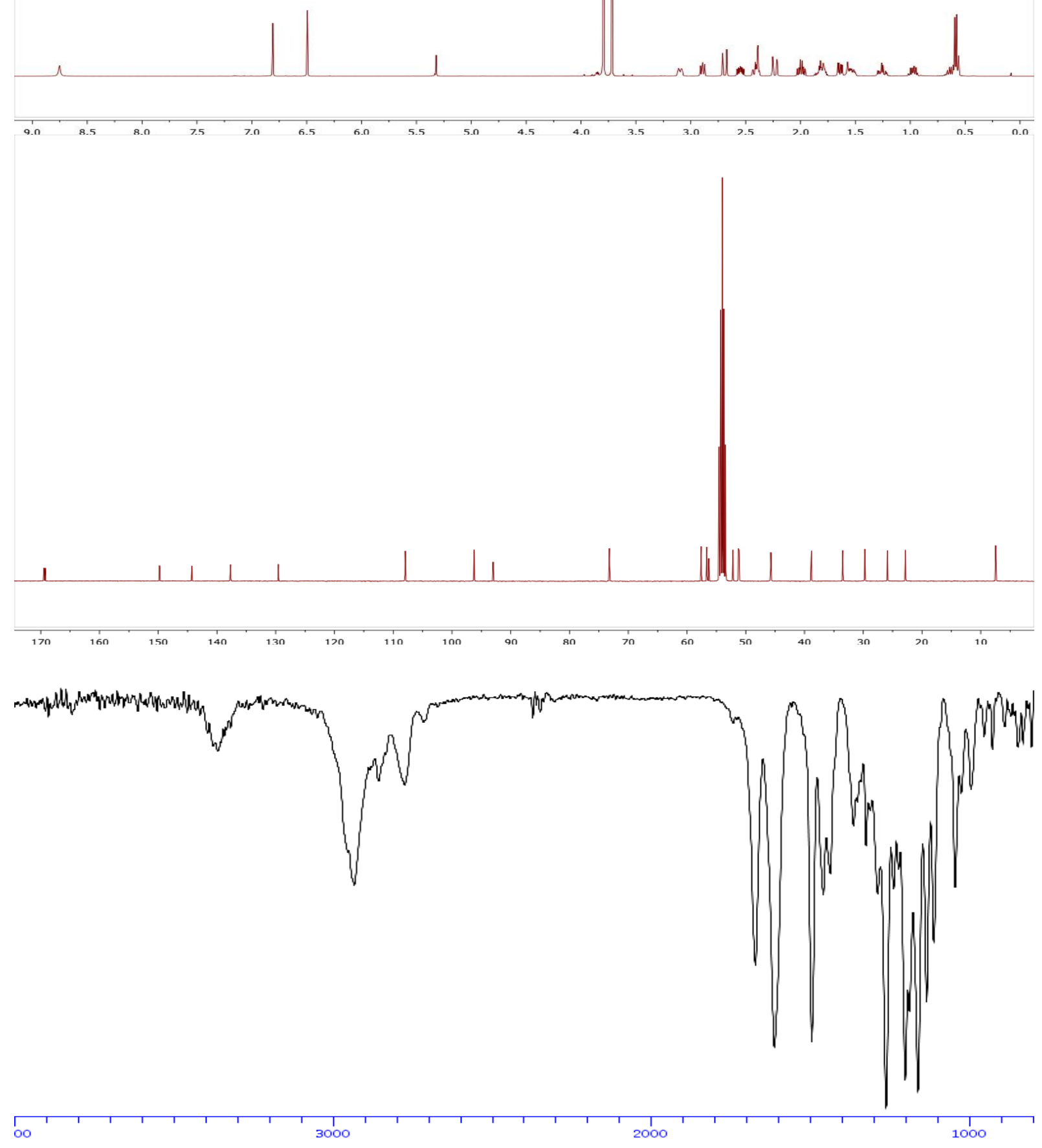


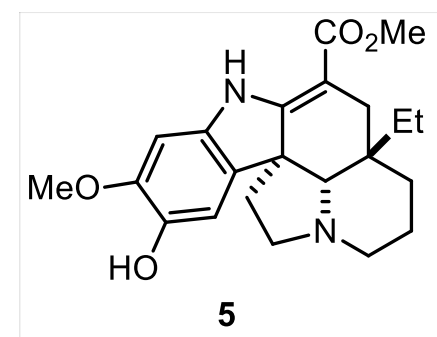

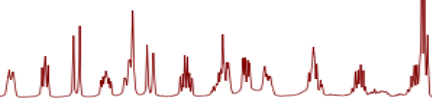
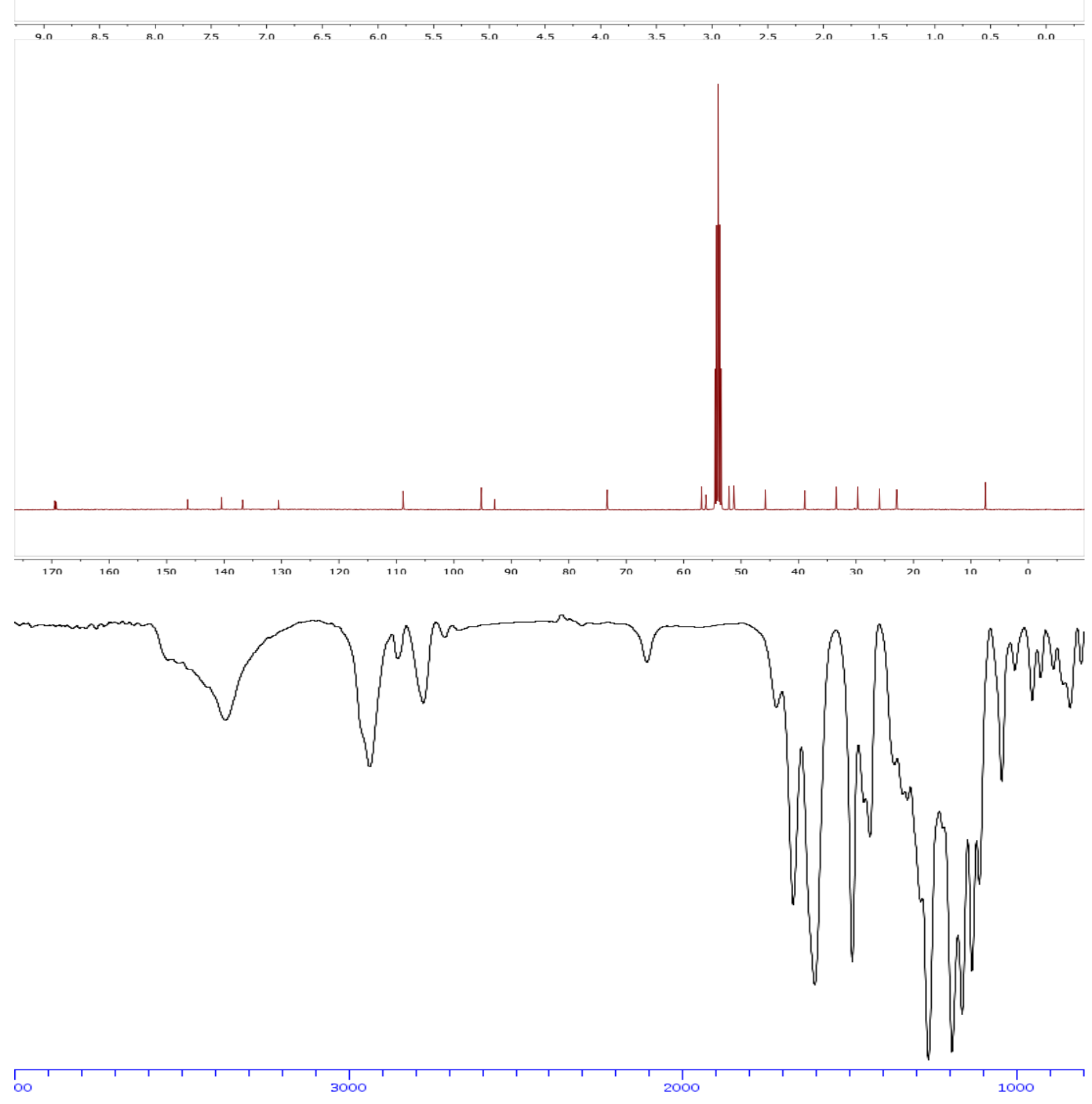